\title{
Management of Longleaf Pine Woodlands for Threatened and Endangered Species
}

by

Mary Harper, Ann-Marie Trame, Richard A. Fischer, and Chester O. Martin

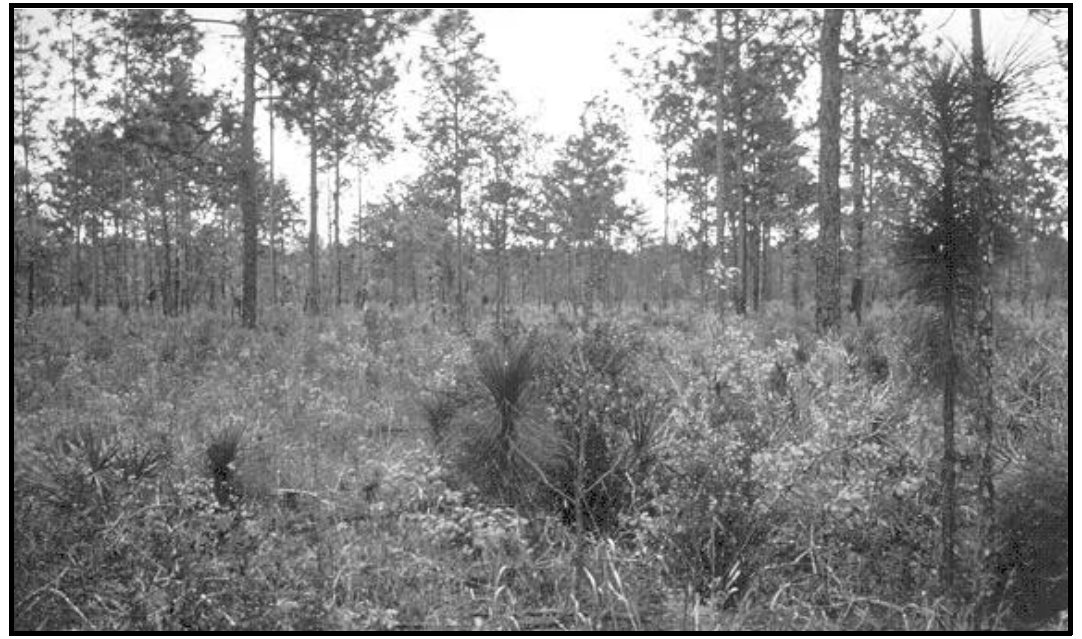

Longleaf pine woodlands on military installations support multiple uses, including the Department of Defense (DoD) training and testing mission; threatened, endangered, and sensitive species (TES) conservation; and forest commodities (e.g., timber, pine straw) production. This report documents strategies to manage TES and their habitats on a plant community basis, using methods that apply to multiple species, and using methods that apply across the southeastern region of the United States.

This report combines the pine flatwoods and sandhills communities because they have several features that link them. Ecological descriptions are provided for each community, along with available information about community occurrences on DoD installations throughout the southeast region. Known occurrences of plant and animal TES associated with longleaf pine woodlands on DoD lands are also reported. Known and potential impacts to the integrity of longleaf pine woodlands as TES habitat, and to associated species are reported. Impacts may be related to habitat fragmentation, or changes in community composition, structure and function due to altered fire regime, hydrologic patterns, soil stability and structure, groundcover integrity, or the invasion of exotic or pest species. Management recommendations are made within an ecosystembased, adaptive management context.

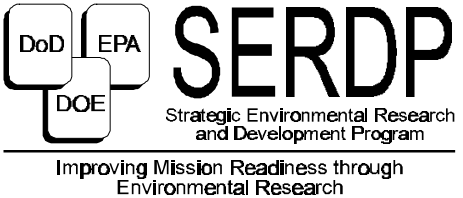


SF 298 


\section{Foreword}

This study was conducted for the Strategic Environmental Research and Development Program (SERDP) under the SERDP study, "Regional Guidelines for Managing Threatened and E ndangered Species Habitats." Brad Smith is Executive Director, SERDP. Thetechnical monitor was Femi Ayorinde, SERDP Conservation Program Manager.

The work was performed by the Natural Resource Assessment and Managment Division (LL-N) of the Land Management Laboratory (LL), U.S. Army Construction Engineering Research Laboratories (USACERL) and the Natural Resources Division (EL), U.S. Army Engineer Waterways Experiment Station (WES), Vicksburg, MS. Mary G. Harper was employed as a Research Associate under an interagency agreement with the U.S. Forest Service, Rocky Mountain Range and Forest Experiment Station, and Colorado State University. Ms. Harper was responsible for the ecological description of the community, most general land use impact analyses, and recommendations for management of the community and plant threatened and endangered species (TES) associated with the community. The USACE RL principal investigator was Ann-Marie Trame, who was responsible for information pertaining to military activities, and soil erosion and compaction. Dr. Richard A. Fischer and Chester O. Martin (WES) were responsible for information pertaining to animal TES.

Kevin Robertson (USACERL) provided valuable technical assistance and contributed information to the appendices. William Whitworth (USACERL) provided valuable technical assistance and made final improvements to the manuscript. Tiffany A. Cook (WES) conducted literature surveys. The USACERL technical editor was Linda L. Wheatley, Technical Information Team.

COL J ames A. Walter is Commander and Dr. Michael J . O'Connor is Director of USACERL. 


\section{Contents}

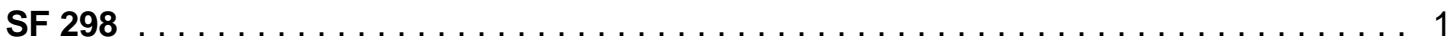

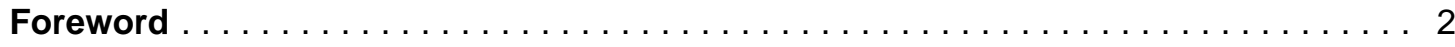

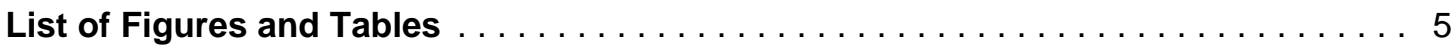

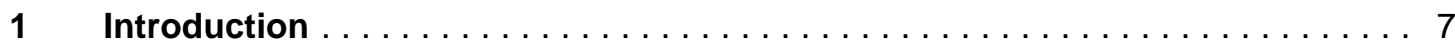

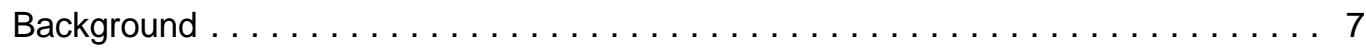

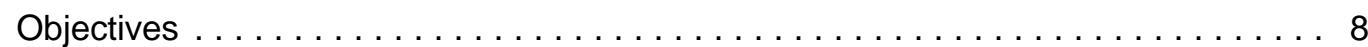

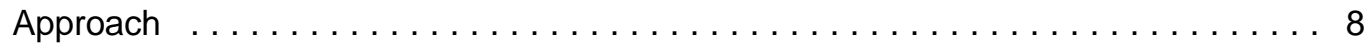

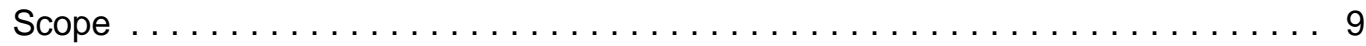

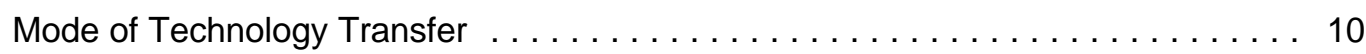

$2 \quad$ Longleaf Pine-dominated Communities $\ldots \ldots \ldots \ldots \ldots \ldots \ldots \ldots \ldots \ldots$

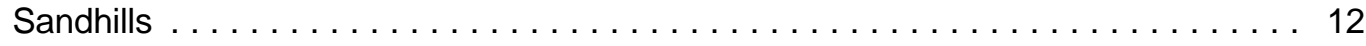

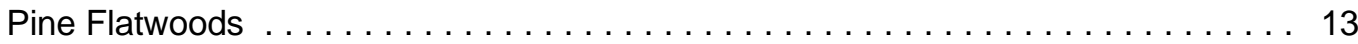

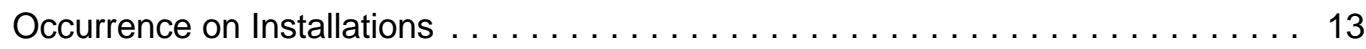

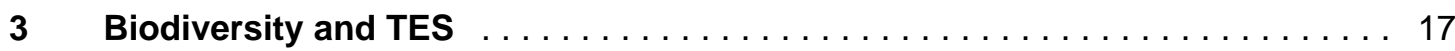

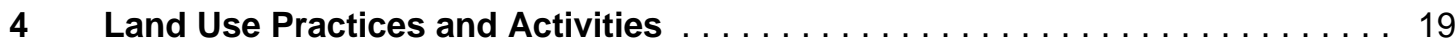

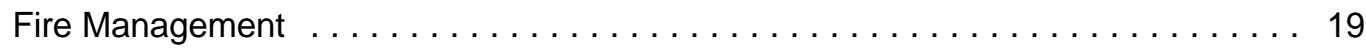

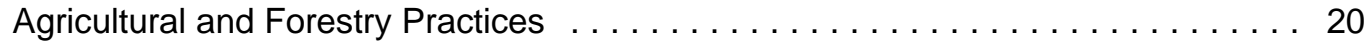

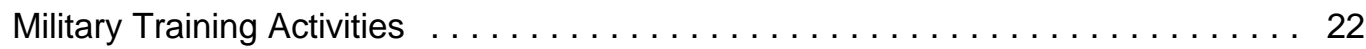

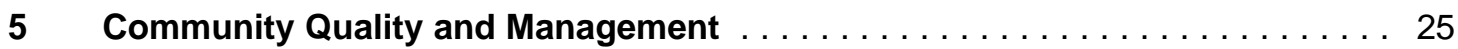

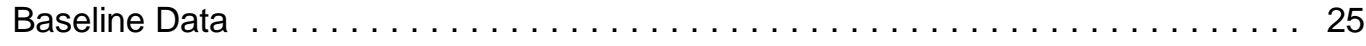

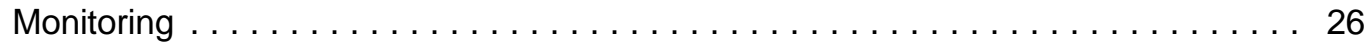

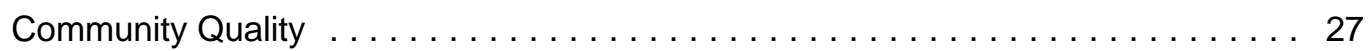

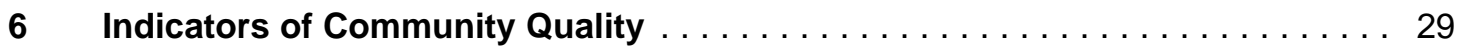

Wiregrass/Bunchgrass Dominance $\ldots \ldots \ldots \ldots \ldots \ldots \ldots \ldots \ldots \ldots \ldots . \ldots \ldots$

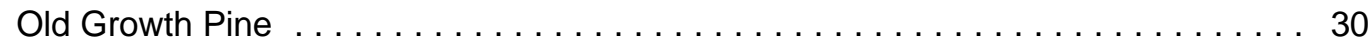

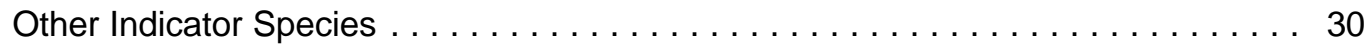

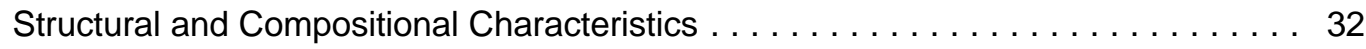

$7 \quad$ Impacts and Management Recommendations $\ldots \ldots \ldots \ldots \ldots \ldots \ldots \ldots \ldots$ 
Fragmentation and Land-Use Conversion $\ldots \ldots \ldots \ldots \ldots \ldots \ldots \ldots \ldots \ldots$

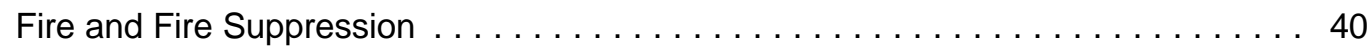

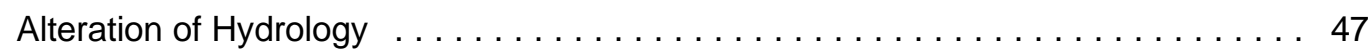

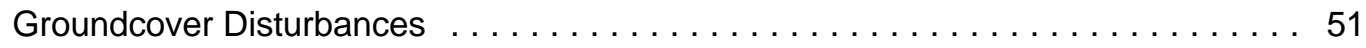

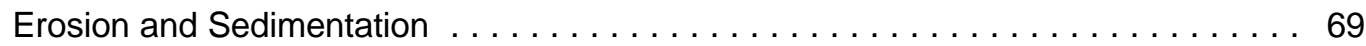

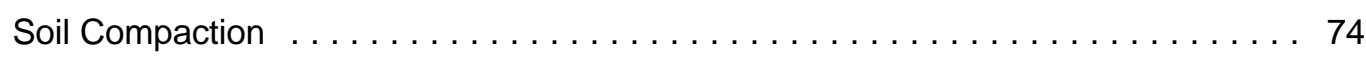

Exotic and Pest Species . . . . . . . . . . . . . . . . . . . . 79

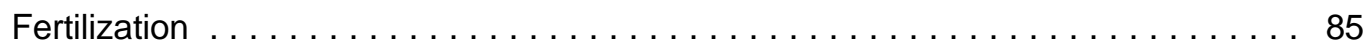

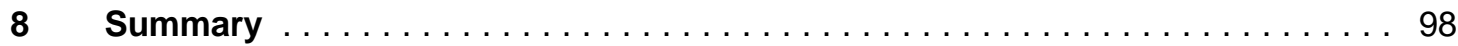

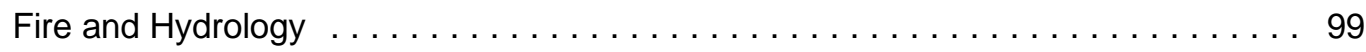

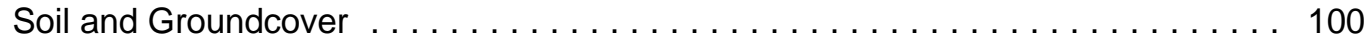

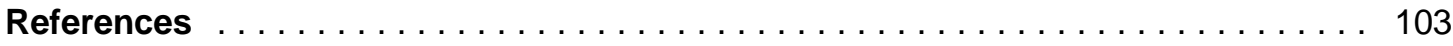

Appendix A: An Ecological Description of the Sandhills Community . . . . . . . 125

Appendix B: An Ecological Description of the Pine Flatwoods Community $\ldots \ldots \ldots 130$

Appendix C: $\quad$ Plant TES Occurring in Flatwoods and Sandhills on Military

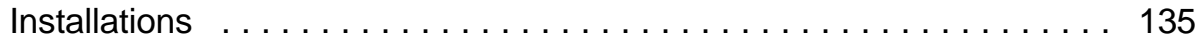

Appendix D: Animal TES Occurring in Flatwoods and Sandhills on Military

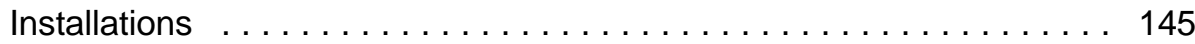

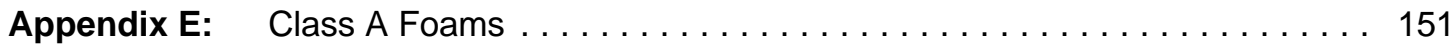

Distribution 


\section{List of Figures and Tables}

\section{Figures}

1 The range of longleaf pine-dominated communities (vertical lines) in the southeastern United States falls across several physiographic provinces . . . 11

2 Sandhills community in North Carolina . . . . . . . . . . . . . . . . . . 15

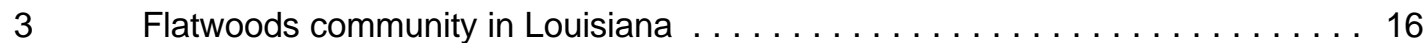

$4 \quad$ Occupational (bivouac) sites, assembly areas, and tank maneuver areas become barren, which fragments fuel sources and prevents fire spread

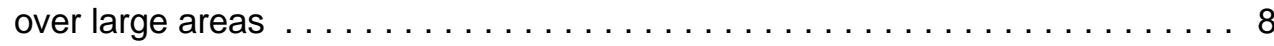

5 Early stages of woody species invasion due to infrequent burning in a sandhills community $\ldots \ldots \ldots \ldots \ldots \ldots \ldots \ldots \ldots \ldots \ldots \ldots \ldots \ldots \ldots \ldots$

$6 \quad$ Heavy vehicle use leads to altered hydrologyNormal sheet flow becomes disrupted as ponding occurs as a result of changes in soil structure $\ldots \ldots \ldots 88$

$7 \quad$ Dense stand of wiregrass in sandhills community $\ldots \ldots \ldots \ldots \ldots \ldots \ldots$

$8 \quad$ Soil disturbance from mechanical timber operations $\ldots \ldots \ldots \ldots \ldots \ldots \ldots 89$

9 Disturbance to sandhills ground cover in the loading deck area of a timber

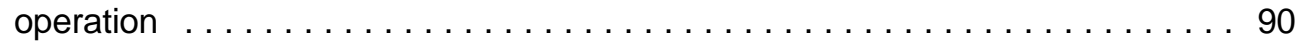

10 Some ground cover (e.g., wiregrass) remains intact after logging opera-

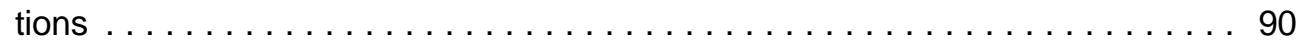

11 Off-road tank traffic in this flatwood community led to rutting, ponding, fire suppression, and consequential changes in the composition and structure

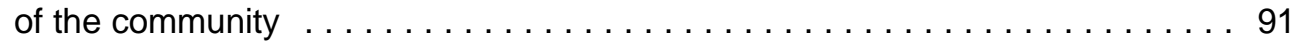

12 Damage to soils, ground cover, and woody regeneration typical of intensively used staging or assembly areas $\ldots \ldots \ldots \ldots \ldots \ldots \ldots \ldots$ 
13 Damage to soils (compaction), ground cover, and overstory trees typical

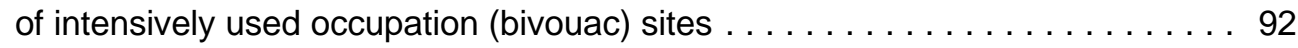

$14 \quad$ Longleaf pine restoration project on Fort Jackson, SC $\ldots \ldots \ldots \ldots \ldots$. . . 92

15 Erosion on sandy, sloped soils usually leads to gully erosion $\ldots \ldots \ldots \ldots 93$

16 Severe sedimentation into a natural stream caused by intensive tank maneuvers in nearby upland areas $\ldots \ldots \ldots \ldots \ldots \ldots \ldots \ldots \ldots \ldots \ldots$

\section{Tables}

1 Occurrence of pine flatwoods and sandhills on military installations in the

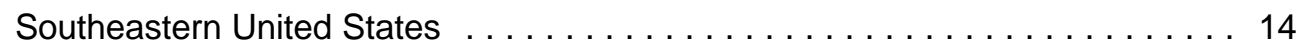

2 Tree harvesting methods used in pine flatwoods and sandhills in the Southeastern United States . . . . . . . . . . . . . . . . . . . . 24

3 List of military activities that can potentially alter longleaf pine communities on military installations in the Southeastern United States . . . . . . . . . 24

$4 \quad$ Activities that lead to fire suppression in longleaf pine communities $\ldots \ldots .95$

5 Activities that alter the hydrology in wetland inclusions within pine

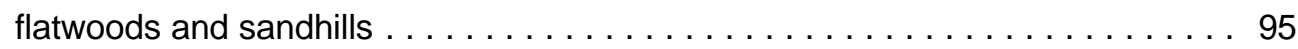

$6 \quad$ Native plant species that have potential for erosion control plantings in

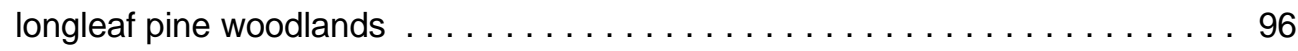

7 Activities that may lead to invasion of pine flatwoods and sandhills by species not native to the community $\ldots \ldots \ldots \ldots \ldots \ldots \ldots \ldots \ldots \ldots$

8 Activities that could lead to artificially increased fertility in pine flatwoods

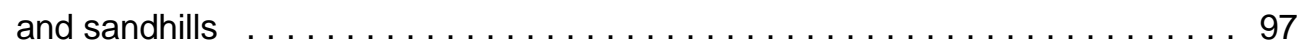

C1 Federally listed threatened, endangered, species at risk, candidate plant species, and species at risk occurring in flatwoods and sandhills on installations in the southeast region 136

D1 Federally listed candidate animal species, and animal species at risk known to occur in the Longleaf Pine-Turkey Oak sandhills community On at least one military installation in the southeastern United States 


\section{Introduction}

\section{Background}

Longleaf pine woodlands on military installations support multiple uses, including the Department of Defense (DoD) training and testing mission, threatened, endangered, and sensitivespecies (TES ${ }^{*}$ ) conservation, and forest commodities (e.g., timber, pine straw) production. Despite the primacy of the military training and testing mission, installations are required to maintain robust TES populations into the foreseeable future.

Management approaches to protecting TES, other natural resources, and natural plant communities are often designed to address immediate and local problems ( $M$. Imlay, professional discussion, 18 August 1995). Although this approach can be rewarding and effective for an individual installation, it precludes any organized understanding of land-use impacts, or sharing of lessons learned, and can sometimes lead to repeated, inefficient efforts to solve similar problems throughout a region of the country. Duplication of effort needs to be reduced or eliminated.

This report is one product of an interlaboratory effort between theU.S. Army Construction Engineering Research Laboratories (USACERL) and theU.S. Army Engineer Waterways Experiment Station (WES) togeneratehabitat-based management strategies for TES on DoD lands in the southeastern United States (Strategic Environmental Research and Development Program [SERDP] work unit "Regional Guidelines for Managing T\&E Species Habitats"; Martin et al. 1996). This effort is directed at developing strategies to manage TES and their habitats on a plant community basis, using methods that apply to multiple species and that apply across the southeastern United States. Any increase in understanding of the habitat requirements of listed TES will assist training and natural resource personnel in complying with the Endangered Species Act (ESA), while avoiding restrictions on themilitary mission. Furthermore, theresults detailed in this report

\footnotetext{
* The acronym "TES" will be used instead of "T\&E Species" in this report to conform to standard DoD terminology. "Candidate Species" (former C1 species) are also defined as those plant and animal species that, in the opinion of the U.S. Fish and Wildlife Service (USFWS) or National Marine Fisheries Service, may qualify for listing as threatened or endangered pursuant to the Endangered Species Act; and "Species of Concern" (former C2 species).
} 
suggest that a great deal of additional effort is required before the process will be guided by solid scientific information (as required by the ESA).

\section{Objectives}

The objectives of this research were to compile known information, identify gaps in knowledge, and stimulate future research efforts on the potential positive and negative effects of landscape planning, silviculture, military training, and other resource-based activities to plant communities (i.e., longleaf pine woodlands) that serve as high-quality habitat for TES plants in the southeastern United States.

This SE RDP work unit, in particular, was undertaken toreduce duplication of effort towards conservation of TES within the southeastern region. It is hoped that this review of information may be used to improve the ecological and economic effectiveness of TES habitat management. By understanding the ecological requirements of TES and the environmental resilience or sensitivity of TES habitats, installations acquire increased control over TES management and landuse decisions.

\section{Approach}

To identify potential impacts, researchers reviewed the available literature and conducted interviews with community ecologists throughout the southeastern United States, with an emphasis on interviewing those people who have been involved in plant TES and plant community survey work on military installations. Site visits were made to military installations. Potential impacts were also discussed with military natural resources personnel, botanists, community ecologists, and military contractors, such as The Nature Conservancy (TNC) or state Natural Heritage Program (NHP) staff. A list of experts contacted is included at the end of the references list. Information al so was taken from installation TES survey reports in which impacts and management wereaddressed. Land Condition Trend Analysis (LCTA) reports, Land Rehabilitation and Maintenance (LRAM) data, and academic and Federal agency literature on logging and recreational impacts to plant communities were also used. 


\section{Scope}

Within the context of the larger DoD mission, TES populations can be maintained through the following framework: (1) identify mission requirements, (2) identify TES requirements, (3) identify ideal compromises for meeting both TES and mission requirements, and (4) pursue these compromises and develop realistic, workable compromises. The fourth step should be executed through professional management of TES populations, as much as possible, to reducerestrictions on themilitary mission. This document partially contributes to the total TES and land-management process. It provides information to assist in identifying the needs of TES (step 2), and perhaps will assist in identifying options for compromise as well (step 3).

This report focuses on plant communities because they provide habitat for multiple species. By managing for plant communities, DoD has the opportunity to conserve multipleTES simultaneously. Plant communities are less ambiguous entities than complete ecosystems, and have been described and cataloged for many decades by ecol ogists and biogeographers. They provide a useful basis on which to understand and manage the natural systems that support military training and other land uses.

For purposes of management, this report combines the pineflatwoods and sandhills communities because they have several features that link them. Historically, pine flatwoods and sandhills dominated many upland areas of the southeastern Coastal Plain, forming a matrix in which other communities were embedded (Noss 1988). Sandhills occupied well-drained xeric ridges and rolling uplands, and graded into flatwoods, which occurred on poorly drained flats or terraces (Myers 1990). Both communities require frequent fire for maintenance (Stout and Marion 1993; Ware et al. 1993), and have a number of plant and animal species in common (Harcombe et al. 1993; Myers 1990; Peet and Allard 1993). F requently burned flatwoods and sandhills are similar in structure, both having a sparse canopy of pines (usually longleaf [Pinus palustris]) and a diverse understory dominated by wiregrasses (Aristida stricta or A. beytrichiana) or bluestems (Andropogon spp. and Schizachyrium spp.) (Christensen 1988; Harcombe et al. 1993; Myers 1990; Peet and Allard 1993).

The range of pine flatwoods and sandhills generally follow the distribution of longleaf pine in the southeastern United States (Figure 1). ${ }^{*}$ This distribution is dosely al igned with the Southeastern Region designated by early efforts in thework

\footnotetext{
* Figures and tables are located at the end of the chapters in which they are first referenced.
} 
unit (see Martin et al. 1996). Recommendations within this report are intended to be applied within this Southeastern Region.

Due to the scope of this report, specific management recommendations are to be considered for areas that trainers and resource managers recognize and manage as endangered species habitat. Many of the most restrictive land-use recommendations are made for areas that are al so recognized as protected wetlands due to their sensitive hydrology. These recommendations are not intended to be applied across entire DoD installations (e.g., on areas designated as maneuver training zones).

\section{Mode of Technology Transfer}

This report is to be used by DoD natural resource policymakers, installation land managers, and the natural resource research community, in conjunction with associated documents produced under this SERDP work unit (e.g., Trame and Harper 1997; Harper and Trame, in prep; and Trame and Tazik 1995) to (1) develop ecosystem-based approaches to describe natural communities and TES habitat in relation to military activities, (2) evaluate military-related effects on those communities, (3) develop community-based strategies for supporting both military land use and TES habitat management, and (4) devel op management solutions for military impacts to natural communities when management for TES habitat is a priority for a particular location.

Results of this report will be presented at the annual SERDP Symposium. In addition, this and companion volumes have been identified for life-cycletechnology demonstration and support in the Conservation Technology Infusion effort being developed under the Army's environmental science and technology process. 


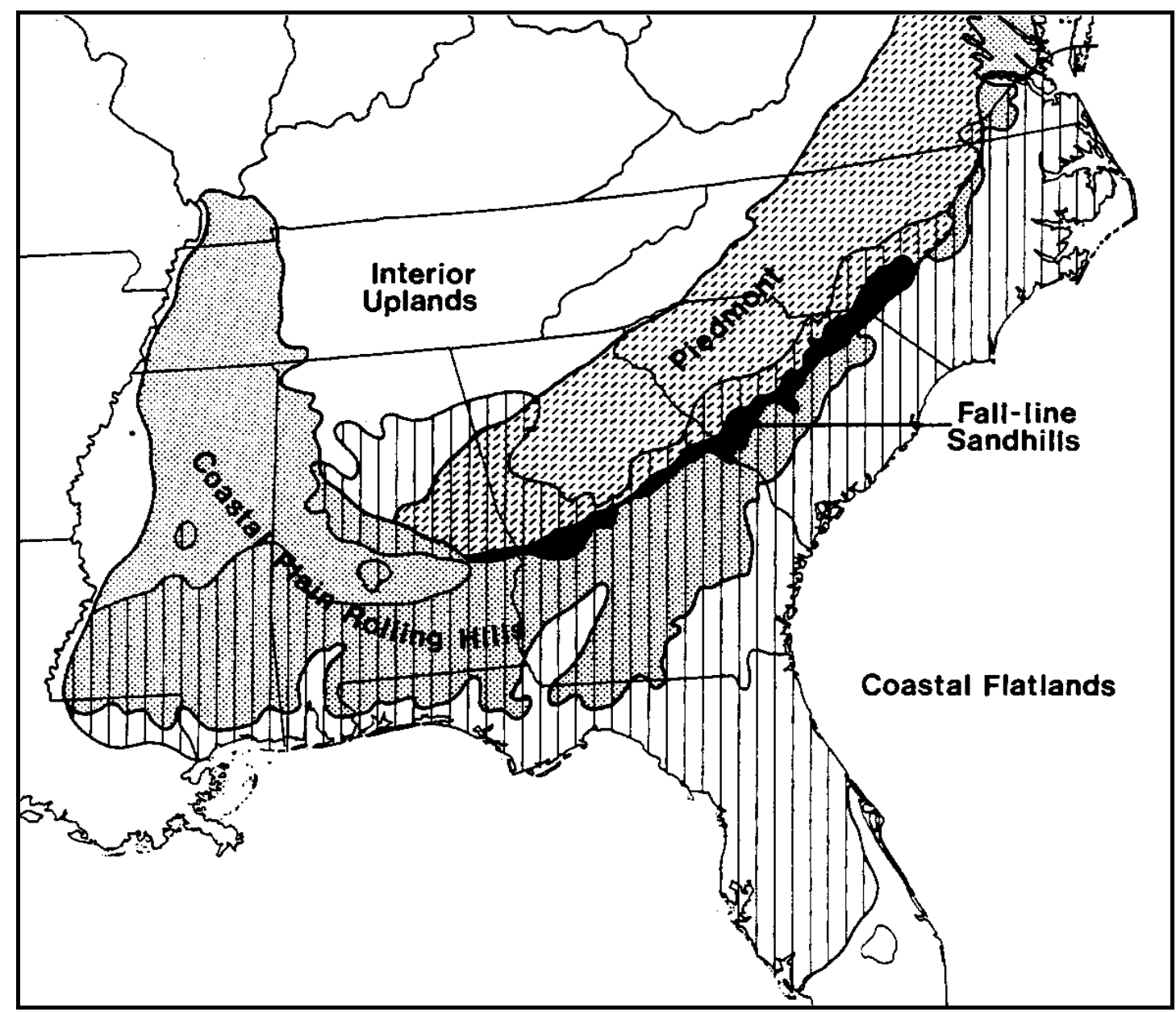

Figure 1. The range of longleaf pine-dominated communities (vertical lines) in the southeastern United States falls across several physiographic provinces. 


\section{Longleaf Pine-dominated Communities}

\section{Sandhills}

Longleaf pine-dominated sandhills occur al ong the outer Coastal Plain from eastern Virginia to Florida and west to the Mississippi River. Stands of Iongleaf pine also occupy the fall line of Alabama, Georgia, North Carolina, and South Carolina. (The fall line marks the separation between the Piedmont and Coastal Plain physiographic regions in the Southeastern United States; see Figure 1). The community generally occurs in areas with rolling topography that have well-drained, dry to xeric (very dry) sandy soils (Stout and Marion 1993). Examples occur on morethan 20 military installations in the Southeast (Table 1).

Community structure is characterized by an open, sparse canopy of pine, an open understory dominated by scrubby oaks, and a herbaceous ground layer consisting of various grasses and forbs (Myers 1990) (Figure 2). Physiognomy varies with moisture, fire regime, and geographic location. Longleaf pine dominates the canopy, except in southeastern and south-central Florida stands, which may consist of slash pine (P. elliottii) or both longl eaf and slash pine, and in eastern Texas north of the range of longleaf, where shortleaf (P. echinata) and loblolly pine (P. taeda) codominate (Christensen 1988, Stout and Marion 1993). Modification by humans has led to the dominance of slash pine or sand pine (P. clausa) in some sandhill canopies in Florida. In some cases, the pine canopy has been removed and the understory scrub oaks have become dominant (Myers 1990). Turkey oak dominate the understory in xeric sites east of the Mississippi River, but in the Big Thicket region of eastern Texas, bluejack oak (Q. incana) and post oak (Q. stellata) replace turkey oak (Christensen 1988, Stout and Marion 1993). In Louisiana, blackjack oak (Q. marilandica), sandhill post oak (Q. margaretta), and bluejack oak are common associates in longleaf pine sandhills (L. Smith, pers. comm., 1997). Wiregrass (A. stricta in the Carolinas; and A. beytrichiana in southern South Carolina, and in Florida west to J ackson County, MS; Peet 1993) dominate the understory in community occurrences east of eastern Mississippi. In more loamy, less sandy habitats, and also west of the range of wiregrass, bluestems increase in importance (Harcombe et al. 1993; Peet and Allard 1993). Appendix A gives a detailed ecological description of sandhill communities. 


\section{Pine Flatwoods}

Pine flatwoods occur on the Coastal Plain from southeastern Virginia south to Florida and west to Texas (Figure 1), and have been documented on over 20 military installations (see Table 1). These communities occur on extensive flats or terraces, and have low, usually flat to gently undulating topography (Stout and Marion 1993). The soils are generally poorly drained sands with varying amounts of clay (Abrahamson and Hartnett 1990). Pine flatwoods typically have a ground layer of low vegetation and an emergent tree layer of pines with limbless lower trunks (Figure 3), but physiognomy varies markedly with fire regimeand moisture (Stout and Marion 1993). For this reason, some authors have divided this community into flatwoods and savannas, with flatwoods being fire-suppressed communities that have a well-developed woody understory and a sparse groundcover, and savannas having a sparse canopy of pines and a diverse groundcover (Christensen 1988). Longleaf pine, slash pine, and pond pine ( $P$. serotina) usually dominate the canopy in pure stands or various combinations. Understory species include gallberry (Ilex glabra), shiny blueberry (Vaccinium myrsinites), fetterbush (Lyonia lucida), dwarf live oak (Q. minima), runner oak (Q. pumila), sand live oak (Q. geminata), hairy laurel (Kalmia hirsuta), and wax myrtle (Myrica cerifera). Saw palmetto (Serenoa repens) also may be a dominant understory component throughout its range. The dominant grass is wiregrass east of eastern Mississippi (Stout and Marion 1993). Other important grasses (and dominant grasses outside the range of wiregrass) are bluestems (Schizachyrium spp.), broomsedges (Andropogon spp.), muhlys (Muhlenbergia spp.), dropseeds (Sporobolus spp.), and toothache grass (Ctenium aromaticum) (Harcombe et al. 1993, Peet and Allard 1993). A ppendix B is a detailed ecological description of pine flatwoods.

\section{Occurrence on Installations}

Only about 25 percent of the remaining mature longleaf-slash pine forests are on public lands where they receive varying degrees of protection (reviewed in Ware, Frost, and Doerr 1993; Noss 1988). Well-planned management of these communities and ecosystems on public lands is critical to their continued existence and to the survival of the rare species that depend on them for habitat. Pine flatwoods and sandhill communities frequently occur on military installations in the southeastern United States (Table 1; for acreage estimates see FNAI 1994a; Gulf Engineers \& Consultants, Inc. and Geo-Marine Inc. 1994; Hart and Lester 1993, Howie 1994; Russo et al. 1993; TNC 1995). Significant areas of forested lands on military installations have been converted to pine plantations, with a portion of the 
remaining lands occasionally utilized for forest products (for acreage estimates, see Russo et al. 1993; Howie 1994; FNAI 1994a; NAS J acksonville 1988; NAS Pensacola 1988; NAS Whiting 1991; Alabama Natural Heritage Program 1994; Mount and Diamond 1992; and Hart and Lester 1993).

Table 1. Occurrence of pine flatwoods and sandhills on military installations in the Southeastern United States.

\begin{tabular}{|c|c|c|c|c|c|}
\hline \multirow[t]{2}{*}{ State } & \multirow[t]{2}{*}{ Branch } & \multirow[t]{2}{*}{ Installation } & \multicolumn{2}{|c|}{ Community Type } & \multirow[t]{2}{*}{ Reference } \\
\hline & & & Flatwoods & Sandhills & \\
\hline$A L$ & Army & $\begin{array}{l}\text { Fort McClellan } \\
\text { Fort Rucker }\end{array}$ & & $X$ & $\begin{array}{l}\text { Alabama Natural Heritage Program } \\
(1994) \\
\text { Mount and Diamond (1992) }\end{array}$ \\
\hline \multirow[t]{10}{*}{$\mathrm{FL}$} & Air Force & $\begin{array}{l}\text { Avon Park Air Force Base } \\
\text { (AFB) }\end{array}$ & $x$ & $x$ & Howie (1994) \\
\hline & & Eglin AFB & $X$ & $X$ & $\begin{array}{l}\text { Florida Natural Areas Inventory } \\
\text { (FNAI) (1994b) }\end{array}$ \\
\hline & & $\begin{array}{l}\text { Hurlburt Field } \\
\text { Eglin AFB }\end{array}$ & $X$ & $X$ & Labat-Anderson, Inc. (1994) \\
\hline & & Tyndall AFB & $x$ & & FNAI (1994a) \\
\hline & Army & Camp Blanding & $X$ & $X$ & R. Brozka, pers. comm., 1994 \\
\hline & Navy & $\begin{array}{l}\text { Naval Air Station (NAS) } \\
\text { Cecil Field }\end{array}$ & $X$ & $X$ & $\begin{array}{l}\text { NAS Cecil Field (1988), } \\
\text { Environmental Services \& } \\
\text { Permitting, Inc. (1990) }\end{array}$ \\
\hline & & NAS Jacksonville & $X$ & & $\begin{array}{l}\text { NAS Jacksonville (1988), } \\
\text { Environmental Services \& } \\
\text { Permitting, Inc. (1990) }\end{array}$ \\
\hline & & $\begin{array}{l}\text { McCoy Annex of the } \\
\text { Naval Training Center } \\
\text { Orlando }\end{array}$ & $X$ & & FNAI (1992) \\
\hline & & $\begin{array}{l}\text { NAS Pensacola and } \\
\text { Outlying Field, Bronson }\end{array}$ & $X$ & $\mathrm{X}$ & NAS Pensacola(1988), FNAI (1988) \\
\hline & & NAS Whiting Field & $X$ & $X$ & NAS Whiting Field (1991) \\
\hline \multirow[t]{5}{*}{ GA } & Air Force & Moody AFB & $x$ & & TNC (1994) \\
\hline & Army & Fort Benning & $x$ & $\mathrm{X}$ & $\begin{array}{l}\text { Gulf Engineers \& Consultants and } \\
\text { Geo-Marine, Inc. (1994) }\end{array}$ \\
\hline & & Fort Gordon & $x$ & $\mathrm{X}$ & Moore and Giannasi (1992) \\
\hline & & Fort Stewart & $X$ & $X$ & TNC (1995) \\
\hline & Marine Corps & $\begin{array}{l}\text { Marine Corps Logistics } \\
\text { Base (MCLB) Albany }\end{array}$ & $\mathrm{X}$ & $\mathrm{X}$ & $\begin{array}{l}\text { Georgia Department of Natural } \\
\text { Resources (DNR) (1994) }\end{array}$ \\
\hline \multirow[t]{3}{*}{ LA } & Army & Camp Beauregard & & $\mathrm{X}$ & Mclnnis, Martin, and Teague (1995) \\
\hline & & Camp Villerie & $X$ & & Teague, Mclnnis, and Martin (1995) \\
\hline & & Fort Polk & $X$ & $X$ & R. Stewart, pers. comm., 1995 \\
\hline
\end{tabular}




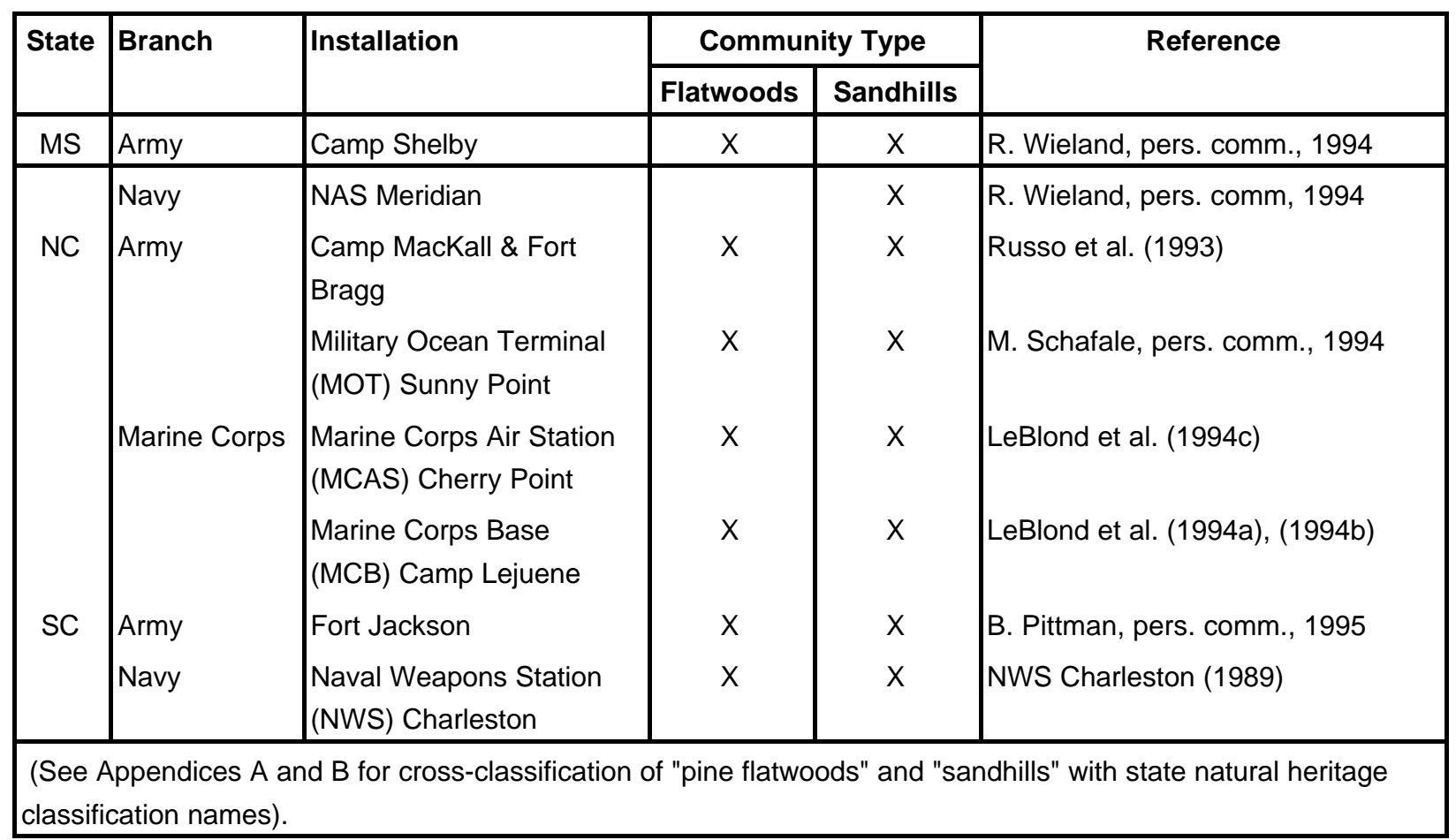

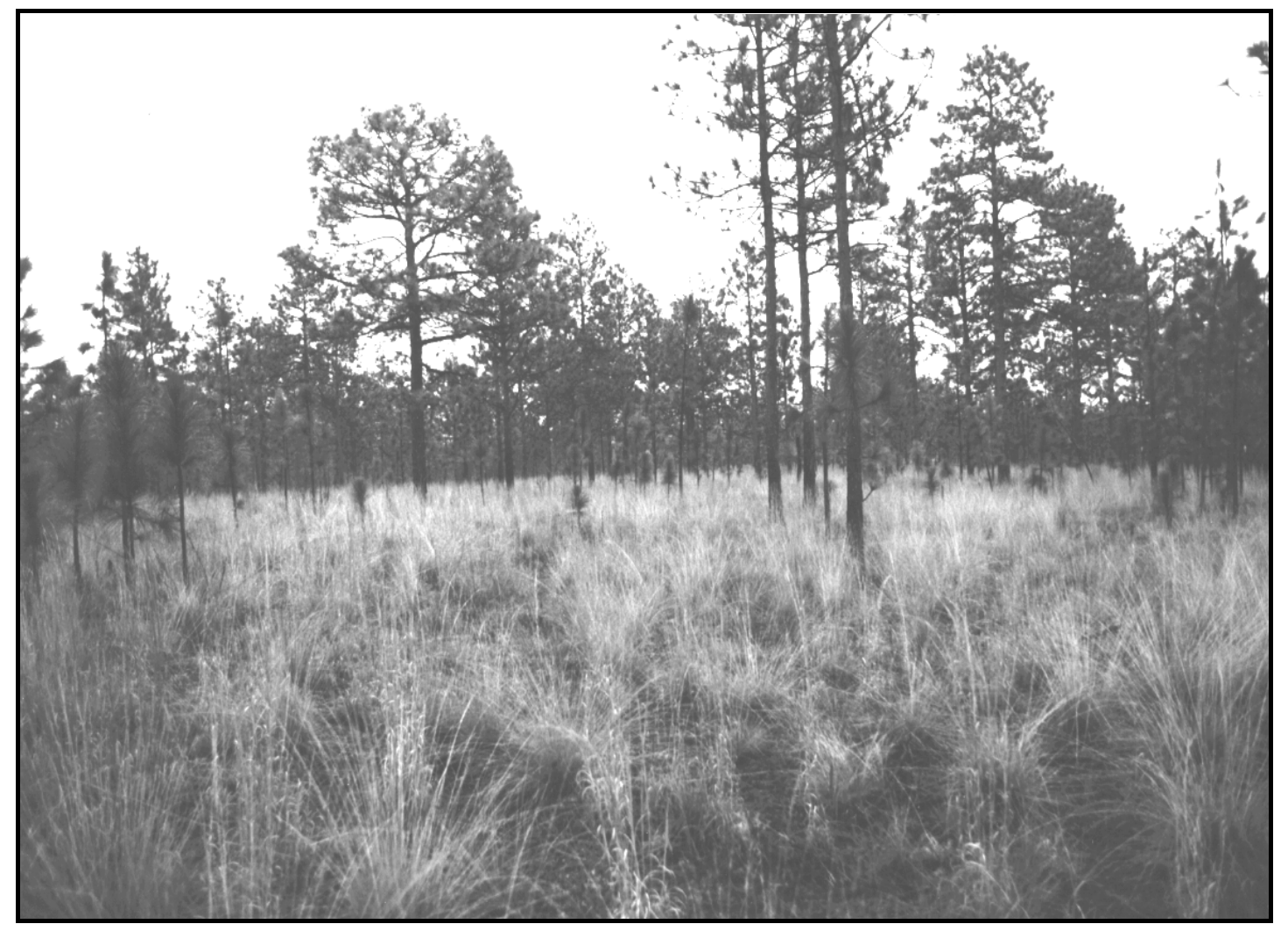

Figure 2. Sandhills community in North Carolina. 


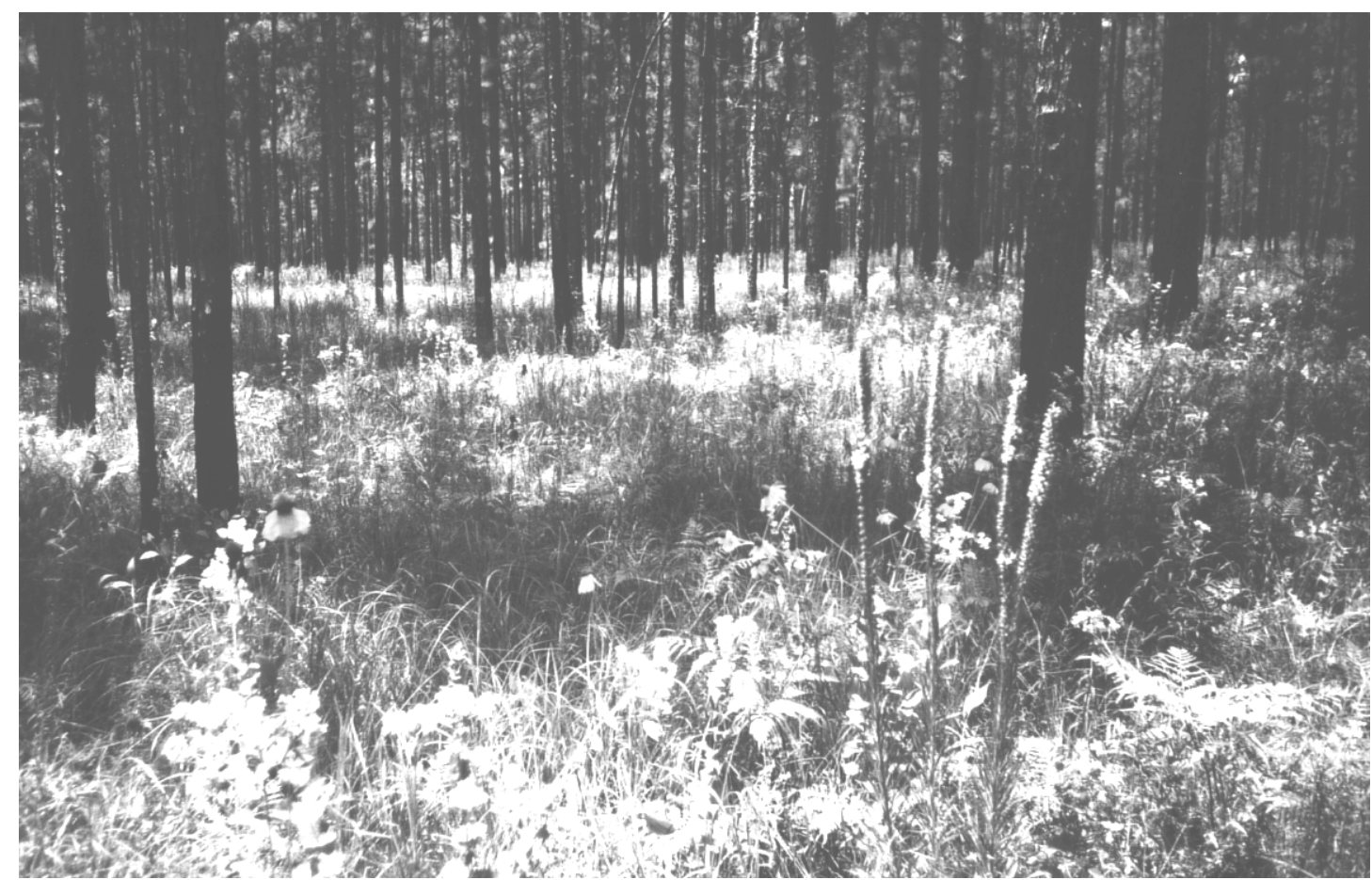

Figure 3. Flatwoods community in Louisiana. 


\section{Biodiversity and TES}

The longleaf pine-bunchgrass (either wiregrass or bluestem) ecosystem was once dominant throughout the Coastal Plain of the southeastern United States. The distribution of this ecosystem has been reduced by approximately 90 to 95 percent (99.9 percent if only remaining ol d growth examples are considered; L. Smith 1997). At the time of European settlement, longl eaf pine communities covered at least 24.5 to 36 million hectares (ha) (60 to 90 million acres); today these communities cover less than 1.6 million ha (4 million acres), and most of this is degraded second growth (Smith 1997). This ecosystem type is considered by some to be critically endangered (N oss, LaRoe, and Scott 1992).

Communities within the longleaf pine ecosystem are extremely diverse, often supporting numerous rareand endemic plant (Hardin and White 1989) and animal (E chternacht and Harris 1993) taxa, making this one of themost important natural systems in the southeastern United States. Hardin and White (1989) listed 191 rare plant taxa as occurring in the wiregrass ecosystem. Six of these taxa have been listed as F ederally endangered, 1 has been proposed for listing as endangered, and 61 are state listed as threatened or endangered in 3 states. In addition, the authors estimated that the wiregrass ecosystem supports 66 rare, locally endemic plant taxa, including 33 from Florida, 2 from North Carolina, 14 from North and South Carolina, 5 from Florida and Georgia, and 5 from Alabama and Florida. Longleaf communities on military installations support several rare plant species including the Federally endangered Chapman's rhododendron (Rhododendron chapmanii), Michaux's sumac (Rhus michauxii), American chaffseed (Schwal bea americana), and rough-leaved loosestrife (Lysimachia asperulaefolia; see Appendix C).

Flatwoods and sandhills also provideseasonal and year-round habitats for a variety of animals, many of which are associated with both plant communities. Sandhills fauna typically are adapted to harsh environmental conditions (e.g., hot summers, cool winters, and desiccation), and many species burrow underground to avoid temperature extremes and minimize water loss (Stout and Marion 1993). Although limited in distribution and abundance, the two plant communities support a number of animal TES (see Appendix D), including the threatened gopher tortoise (Gopherus polyphemus), considered a keystone species for the community 
(Eisenberg 1983), and the endangered red-cockaded woodpecker (RCW) (Picoides boreal is). According to Krusac and Dabney (1994), 53 animal species (17 mammals, 7 birds, 13 reptiles, 6 amphibians, 7 insects, and 1 arachnid) co-occur with redcockaded woodpeckers, for which there are viability concerns because of fire suppression, habitat degradation, and habitat fragmentation. Thedegradation and loss of these two major plant communities also have directly contributed to decreasing populations and reduced distribution of eastern indigo snakes (Drymarchon corais couperi; Speake et al. 1978), gopher frogs (Rana capito spp.; Palis 1995), and pine snakes (Pituophis melanoleucus; J ordan 1995). 


\section{Land Use Practices and Activities}

Remaining pine flatwoods and sandhills have been degraded by past management practices, land uses, and other human created disturbances. Also, many areas currently support multiple land uses. This section is intended to describe the management practices and multiple land uses that sandhills and flatwoods support on military installations. Practices associated with agriculture, fire management, forestry, construction activities, and military training have potential to alter the quality of habitat for TES, which currently depend on remnants of these communities (see Chapter 7, I mpacts and Management Recommendations).

\section{Fire Management}

Prior to the 1920s, flatwoods and sandhills burned frequently during the growing season as a result of fires ignited by lightning strikes. In addition, prescribed fires were often set during the dormant season for game management purposes. Most of the longleaf pine range came under effective fire suppression between 1920 and 1950, leading to the development of a dense forest (Frost 1993). On military installations, frequent fires continued to occur throughout the year in artillery impact areas, with occasional accidental or prescribed fires in other areas. Firemay increase soil erosion in the short term (through removal of vegetation and through the use of fire control plowlines), but it restores conditions for the herbaceous plant species associated with high-quality longleaf pine communities (Haywood, Martin, and Novosad 1995). Today's DoD installation managers must therefore balancethe need to control erosion with the need to sustain fire-dependent communities.

As a means of accidental fire suppression and to control prescribed fires, managers have created plowlines throughout natural communities. Creating plowlines involves removing vegetation down tothemineral soil layer. Historically, plowlines often were placed in ecotones between sandhills or flatwoods and adjacent wetlands (Frost et al. 1986).

Current fire management practices in pine flatwoods and sandhills are discussed in detail in Fire and Fire Suppression, p 40. Fire management includes the use 
of prescribed fire, and the use of plowlines, surfactant foams, and natural wetland barriers to control fire intensity and spread.

\section{Agricultural and Forestry Practices}

Agricultural and forestry practices in pine flatwoods and sandhills include site preparation activities such as disking, chopping, ditching, draining, bedding, and fertilization. Disking improves soil compaction and drainage. Steel blades that penetrate deep into the soil are used to cut and break small stems and roots. Disks are most frequently pulled by crawler tractors, but rubber-tired skidding tractors also may be used. Chopping severs standing vegetation and involves rolling a heavy steel drum studded with radially oriented cutting blades across a site. Drums can be pulled by an articulated rubber-tired skidder or crawler tractor. Ditches are dug and drains installed to increase water drainage and soil aeration, which enhances tree growth. Bedding also improves drainage. This practice involves the formation of mounds of soil using bedding plows pulled by crawler tractors or rubber-tired skidders (Lowery and Gjerstad 1991). Trees are then planted on the mounds. Fertilization of longl eaf soils can improve understory plant growth and production in the short term, but at least one study has found fertilization to belargely unnecessary in areas where fire was controlled (H aywood and Thill 1995).

Activities related to the production of commodities such as logging, turpentining (the removal of gum from live pinetrees), stumping (theremoval of stumps from the ground, usually with crawler tractors), and pinestraw raking (the harvest of fallen pine needles either by hand-raking or tractor-drawn hay rakes and balers) occurred (and all except turpentining still occur) in flatwoods and sandhills. Logging did not affect the forest significantly until 1870. Between 1870 and 1930, intensivelogging removed virtually all remaining virgin forest in the South (Frost 1993). From approximately 1920 to the present, logged forests were converted to plantations, and species such as loblolly and slash pine were planted (Frost 1993). Contemporary logging in flatwoods and sandhills is characterized by the use of heavy machinery (wheel or crawler tractors), the creation of haul roads, and use of log decks and skid trails (Hatchell, Ralston, and Foil 1970). As shown in Table 2, many different tree harvesting cuts are used today. Turpentining occurred from 1834 to approximately 1890. Most mature trees were used for turpentining, which involved cutting the bark from the tree and installing a tap. This practice weakened the trees to the extent that subsequent fires or winds often killed them (Frost 1993). 
Pine beetle control practices are often necessary to protect forest health and minimize economic impacts to the timber industry. Controls range from synthetic pesticide application and selective removal of infected and adjacent trees, to the emerging use of biopesticides (Strom, Goyer, and Hays 1995). Pine beetle infestations generally range in size from individual trees to several hectares (K. Robertson, pers. comm., 1996).

The removal of stumps, snags, and other woody debris associated with stumping, road construction, pest control, and other traditional forestry operations has the potential of negatively impacting biodiversity. Researchers increasingly are recognizing and documenting the biological importance of coarse woody debris in southern forest ecosystem structure and function (McMinn and Crossley 1993; Harvey and Pimentel 1996), both terrestrial and aquatic (Wallace, Grubaugh, and Whiles 1993), in addition to negative consequences associated with woody debris loss (H arvey and Pimentel 1996). Specifically, McM inn and Crossley (1993) provide selected papers asserting the role of coarse woody debris in maintaining regional biological diversity in addition to specific consideration of its importance in seedling recruitment and maintenance of healthy and diverse fish, invertebrate, bird, mammal, herpetofauna, and soil mite communities.

Theability of altered longleaf pine communities on military installations to provide TES habitat in addition to training and testing opportunities varies considerably. Lands that have been ditched, drained, bedded, or subjected to severe mechanical disturbance may no longer be able to support native groundcover or naturally regenerating longleaf pine and may require significant rehabilitation efforts to restore. Regardless of disturbance to groundcover, conversion to plantations can lead to the development of a dense canopy of pines that eliminates habitat for the shade-intolerant plant species characteristic of the herb layer in natural communities. However, forested lands being less intensively managed may still support TES. For example, the Northern Training Area of Fort Bragg, NC, was purchased from the International Paper Company in 1986, when themajority of the forest had been clearcut and converted to slash pine plantations. The RCW, wiregrass, and several plant TES continue to persist in these altered communities (Russo et al. 1993).

Nonetheless, conversion of natural pine flatwoods and sandhills to even-aged pine plantations can reduce or degrade available habitat for many animal TES inhabiting these communities. Reported examples include the loss of habitat for pine snakes (J ordan 1995) and flatwoods salamanders (Ambystoma cingulatum; Means, Palis, and Baggett 1994); reduction in groundcover vegetation (e.g., forage availability) for gopher tortoises because of shading by the dense overstory (Diemer 
1989); development of stands that are not burned frequently enough or have trees that are too densely stocked for eastern indigo snakes (USFWS 1982); and development of unsuitable foraging habitat for southeastern American kestrels (Falco sparverius paulus) (Bohall 1984). Variations in modern sivicultural practices, such as the use of irregular shelterwoods, may be compatible with RCW management, although this continues to be debated by scientists (Rudolph and Conner 1996). Managing to protect TES and unique natural communities on installations may requireless emphasis on traditional silvicultural practices in the future.

Activities not related toforestry that affect flatwoods and sandhills include livestock grazing, creation of wildlife food plots, and conversion to agricultural lands. According to Frost (1993), hogs, cattle, mules, sheep, and goats have grazed flatwoods and sandhills since European settlement. Feral hogs (Sus scrofa) have had the greatest effect on tree species, preventing regrowth of longleaf pine. Hogs reached high densities throughout the range of longleaf pine in 1860, and still run wild in some areas. Open-range grazing ended between 1880 and 1930, and Iongleaf pine regenerated on many of these areas before the era of fire suppression (F rost 1993). Wildlife food plots require the artificial establishment of introduced or cultivated species for the purpose of feeding increased populations of game species. Preparation involves clearing native vegetation, often in openings created by logging. Conversion to farms supporting agricultural species also occurred in flatwoods and sandhills. Some mixed pine-hardwood communities in existence today developed when agricultural fields were left fallow (Means and Grow 1985).

\section{Military Training Activities}

Dismounted military training occurs during portions of training exercises when soldiers are on foot. Activities may include patrolling, navigation, marching, and occupational exercises (bivouacking) without vehicles. Effects on natural resources can be similar to those generated in campgrounds or along hiking trails. Land navigation exercises are nonmechanized, orienteering exercises in which individual soldiers or small groups must use a map in unfamiliar terrain to reach a specified location. Platoons and companies must master the skills of scouting and patrolling in units of 33 to 120 soldiers. They are expected to operate in any terrain and under any weather conditions (Michigan Department of Military Affairs [Michigan DMA] 1994). Infantry units are rapidly deployed in a dispersed pattern throughout a large area. Their mission is to conduct synchronized but decentralized operations (Army Field Manual [AFM] 71-100, 1990). 
Occupation of land (bivouacking) occurs anytimea unit stops to set up security, rest soldiers or equipment, construct fighting positions, camouflage vehicles and equipment, or stay in one place for any length of time. These actions have potential to damage sites through vehicleactivity, foot traffic, and digging (Department of the Army 1993). Firing points and other areas where troops gather can experience the same damage.

Mechanized and armored units are dominated by heavy tracked vehicles. They provide mobile, well-protected firepower. They are deployed over large open areas where long-range weapons with flat trajectories can be shot. Movement can occur anywhere on the terrain, up and down hills, and in some cases, through streams and ponds. The terrain is used for protection, so maneuvers such as avoiding open space, avoiding open or high ground, or using depressions for concealment must be practiced (AFM 7-7, 1985). During offensive operations, their mission includes rapid concentrations of power, so mobility is extremely important and requires large expanses of open terrain (AFM 71-100, 1990). Mechanized and armored training cause damage resulting from "viol ently executed vehicle movement" and sustained weapons fire (Michigan DMA 1994).

Because the modern soldier relies on battlefield terrain to provide conceal ment and protection, the terrain is used and modified by all units. For example, soldiers dig fighting positions such as foxholes and tank defolade positions. Engineers must know how to reduce enemy obstacles, create friendly obstacles, and protect soldiers from enemy fire by altering the terrain (AFM 5-100, 1988). Engineer units use modified tanks, road graders, bulldozers, cranes, backhoes, High Mobility MultiPurpose Wheeled Vehicles (HMMWV, more commonly known as "Humvees") and front-end loaders. Engineer activities require movement of massiveamounts of soil. Even the deepest root systems of plants can be damaged during these activities (Trame 1997).

An Army division includes dozens of support and service units that also affect terrain. Signal units must plan, provide, and maintain communication systems between command posts and subordinate units. They use light to medium-sized trucks. Medical Corps units train in field hospital conditions. Most specialized units use wheel ed vehicles, but the potential for support and service units to impact natural resources are minimal compared to fighting operations. Table 3 lists military activities affecting longleaf pine communities. 
Table 2. Tree harvesting methods used in pine flatwoods and sandhills in the Southeastern United States.

\begin{tabular}{|c|c|}
\hline Kind of Cut & Description \\
\hline Clearcut & Timber harvest in which an entire stand of trees is cut. \\
\hline Salvage cut & $\begin{array}{l}\text { Harvesting dead or dying trees or those in danger of being killed to save their } \\
\text { economic value (Farrar 1993). }\end{array}$ \\
\hline Seed-tree cut & $\begin{array}{l}\text { Forestry practice in which } 5 \text { to } 10 \text { residual trees per acre are left on the site after } \\
\text { harvest for the purpose of natural regeneration (Boyer 1993). }\end{array}$ \\
\hline Selection cut & $\begin{array}{l}\text { Forestry practice involving creation and maintenance of an uneven-aged stand. } \\
\text { Individual trees or small groups are harvested at periodic intervals (cutting cycles) of } \\
5 \text { to } 15 \text { years based on species, physical condition, and degree of maturity (Farrar } \\
\text { 1993). }\end{array}$ \\
\hline Shelterwood cut & $\begin{array}{l}\text { A silvicultural system in which mature trees are removed, in a series of cuts, to } \\
\text { achieve a new even-aged stand under the shelter of remaining trees. }\end{array}$ \\
\hline Irregular shelterwood cut & $\begin{array}{l}\text { Harvesting a portion of trees at rotation age, leaving a substantial number of residual } \\
\text { trees scattered across the stand throughout succeeding rotation(s) (Rudolph and } \\
\text { Conner 1996). }\end{array}$ \\
\hline
\end{tabular}

Table 3. List of military activities that can potentially alter longleaf pine communities on military installations in the Southeastern United States.

\begin{tabular}{|c|c|}
\hline Activity & Description \\
\hline Training on foot & $\begin{array}{l}\text { In file on established route; moving cross-country; escape and evasion } \\
\text { training }\end{array}$ \\
\hline Use of tracked tactical vehicle & $\begin{array}{l}\text { In file on established route or moving cross-country; moving cross-country; } \\
\text { crossing stream; tactical maneuver training }\end{array}$ \\
\hline Use of wheeled tactical vehicle & $\begin{array}{l}\text { In file on established route or moving cross-country; moving cross-country; } \\
\text { crossing stream; tactical maneuver training; transport of petroleum, oils, } \\
\text { and lubricants }(\mathrm{POL}) \text { or supplies cross-country }\end{array}$ \\
\hline Military watercraft & In coastal or inland waters, beaches, and dune habitats \\
\hline Airborne operations & $\begin{array}{l}\text { Air drop; firing airborne small arms, or medium and heavy weaponry; hover } \\
\text { aircraft }\end{array}$ \\
\hline Munitions & $\begin{array}{l}\text { Firing small arms, or medium and heavy weaponry; firing missiles and } \\
\text { rockets; use of incendiary devices }\end{array}$ \\
\hline Potential pollution & Use of smoke products, gases \\
\hline Earthmoving activities & $\begin{array}{l}\text { Construction of obstacles, fortifications, or emplacements; engineer heavy } \\
\text { equipment operations }\end{array}$ \\
\hline Miscellaneous activities & $\begin{array}{l}\text { Firefighting, camouflage, bivouacking, bridge-building, assembly/staging } \\
\text { activities }\end{array}$ \\
\hline
\end{tabular}




\section{Community Quality and Management}

\section{Baseline Data}

To practice ecosystem management while keeping several goals in mind (the military mission, protecting TES, production of forest commodities), installations should gather the following baseline information from which they can make management decisions.

- Locations and sizes of TES populations or significant natural features within communities

- Mission land and resource needs to support the training or testing mission(s)

- $\quad$ Kinds of plant communities, and the juxtaposition of different communities within the landscape-Managers also should be aware of the relationship between plants and animals in each community and the habitats on which they depend. I dentification of species and species-assemblages is essential in order to characterize within and between community diversity across watersheds and other landscapes. That is, once the ecological "uniqueness" of communities is determined, the most appropriate community-based management can be determined. Moreover, knowledge about plant/animal lifehistories and plant/animal interactions can help managers plan activities that minimize disturbance to species of concern and overall community dynamics. For example, managers would want to avoid creating a barrier between upland terrestrial habitat for a rare animal species and theaquatic habitat it depends on for breeding.

- Quality and significance of plant communities on the installation-This information should be used to determine which communities have the highest priority for the conservation of TES species. A community generally is deemed high quality if it resembles presettlement conditions (see Community Quality, p 27). Regardless of quality, the community may be highly significant based on rarity or uniqueness of the type. 
- Natural processes which regulate communities and how they have been altered by human activities-It is not enough to identify all species in a community. Rather, processes that allow ecological succession to regress, stabilize, or accelerate must be identified in order to manage for the appropriate seral stage. Additionally, knowledge of processes allows for the development of ecological models, which are predictive tools enjoying a high degree of popularity in the fields of risk assessment and environmental impact analysis. Important processes include fire frequency, human land-use patterns, wetland loss or gain, soil erosion, deforestation/reforestation, community recovery rates (from environmental perturbations), nutrient cycling, productivity, community succession and species replacement (exotic species introduction), population turnover, fecundity, and mortality.

- Interagency cooperation and data compatability/exchange-Interagency cooperation involving activities such as the sharing of information and leveraging of resources to achieve common goals arguably may be among the most important el ements in determining success with an ecosystem approach. Cooperation with non-DoD agencies is needed because few, if any, installations contain closed ecosystems that support sustainable TES populations, and all are influenced by species and processes (hydrology, natural and human-induced impacts) occurring on adjacent lands. Moreover, state agencies and other natural resource-oriented groups often have in-house expertise, extensive libraries, access to a wealth of unpublished information, and can potentially provide much of the baseline information mentioned above. Not only can installations realize savings in time and money, but the citing of non-DoD sources may be perceived as more credible by regulatory agencies and the general public.

\section{Monitoring}

Managers should monitor the effects of their management practices on the communities or features of interest. For the purpose of long-term monitoring, standardized sampling methods should be developed and used. Being able to quantify improvement or degradation of habitats over time is critical to not only evaluate management practices, but to make management decisions as well. Methods as simple as establishing permanent plots or grids are useful for repeated surveys (Whitworth and Hill 1997). Georectified aerial photographs can be useful in monitoring landscape and community changes over time. Keeping accurate records of land use is also important (e.g., detailed notes of fire occurrence and species response, as well as silvicultural [forestry] techniques). 


\section{Community Quality}

Managers at Eglin AFB , FL, havedevel oped a system to classify community qual ity known as the "E cological Tier System" (Dept. of the Air F orce 1993). This system has also been used at Camp Blanding, FL (FNAI and TNC 1995). Determination of community quality has obvious benefits for TES conservation planning. Low quality communities do not provide the same habitat quality for TES as higher quality communities and, therefore, should be treated differently in terms of protection, restoration efforts, and allowable land uses. Use of a quality-ranking system for management purposes can assure that protection priority is given to highest quality TES habitat. Furthermore, use of this system can ensure that restoration activities are used for communities that have the potential to become high-quality TES habitat with minimum restoration efforts. Similarly, use of a quality-ranking system can ensure that efforts are not wasted in the restoration of low quality communities. Finally, plant communities on installations are subject to multiple land uses, and use of a quality-ranking system in combination with an assessment of impacts of various land uses can allow managers to determine which activities are appropriate in which communities, based on the potential to provide quality habitat for TES. The ranking system developed for Eglin AFB has been adapted for this report, and will be referred to repeatedly in the management sections that follow (Dept. of the Air Force 1993):

TYPE I - High quality community: "Portions of vegetative communities which are in or closely approximate their natural state.... These areas have experienced relatively few disruptive events. Examples are areas of old growth or relatively undisturbed vegetation. Management activities should be predominantly in the maintenance category, utilizing methods that mimic natural formative forces such as prescribed fire."

TYPE II - Intermediate quality community: "Portions of vegetative communities that still retain a good representation and distribution of associated species and which have been exposed to moderate amounts and intensities of disruptive events.... These are areas where ecosystem function and viability can be restored through careful, responsible management. Management direction will integrate appropriate management activities to accomplish restoration and maintenance objectives. Restoration activities may include practices that will accelerate change in the desired direction (i.e., use of herbicides, and/or mechanical methods of hardwood control, supplemental planting of longleaf seedlings)." 
TYPE III - Moderately low quality community: "Portions of vegetative communities that do not retain a good representation and distribution of associated species and which have been exposed to severe amounts and intensities of disruptive events.... These are areas where restoration of ecosystem function and viability might be possible, but would require significant and intensive management commitment over extended periods of time. Depending on land-use priorities, management direction may encourage a return to a more natural vegetative association over thelong term and/or may include intensive use of traditional management techniques."

TYPE IV - Lowest quality community: “....sites that either will not be or are not capable of being restored under any likely realistic scenario because of dedicated land use. Type IV areas include cleared test ranges, sewage disposal spray fields, urban areas, main roads, designated clay pits, power line rights-of-way, and possibly some wildland interface areas."

In addition to giving a quality ranking to a community based on naturalness, managers may wish to use other parameters to determine what kind of activities should occur in communities, and which communities should be protected from them. For example, presence of rare species, overall diversity, unusual species combinations, and diverse physical features (e.g., soil types, hydrologicregimes, and topographic situations) should be considered. Some systems consider all of these parameters and rank a site based on them. 


\section{Indicators of Community Quality}

\section{Wiregrass/Bunchgrass Dominance}

Clewell (1989) found that wiregrass dominance (or co-dominance with bluestems in flatwoods, G. Tanner, pers. comm., 1996) can be a good indicator of a community that has not suffered from fire suppression or soil disturbance. This idea is expanded to include the bunchgrasses, bluestems, and broomsedges west of the range of wiregrass. The range extends from southeastern N orth Carolina to the edge of the Florida Everglades and westward throughout the Florida panhandle, Georgia, southern Alabama, and coastal Mississippi, with a natural gap in South Carolina. Other bunchgrasses dominatetheherbaceous layer in Louisiana and east Texas, but play a similar ecological role.

Within its range, wiregrass is the predominant cover in longleaf pinelands, in nearly all slash pine flatwoods, and in many herbaceous bogs. Once eliminated from a site, reestablishment is difficult, due to negl igible reproduction by seed, and slow rates of vegetative spread. Studies from 30 flatwoods, sandhills and boggy sites have shown that, throughout the range of wiregrass, uniform density averaging 5 wiregrass clumps (or plants) $/ \mathrm{m}^{2}$ ( 0.46 clumps/sq ft) occurs in Type I communities free from fire suppression and moderate to severe soil disturbance. Wiregrass clumps were more dense in sandhills (averaging $5.3 \mathrm{clumps} / \mathrm{m}^{2}[0.49$ dumps/sq ft]) than in flatwoods (averaging 4.6 clumps $/ \mathrm{m}^{2}$ [0.43 clumps/sq ft]). Sites with low densities or irregular distributions of wiregrass consistently showed evidence of past disturbance or prolonged fire suppression, such as "unusual combinations of associated species, hardwood coppice-sprouts, or slight topographic irregularities caused by disturbance...." (Type II or III communities). Examples show that wiregrass can be eliminated from Type III sites after 20 to 40 years of fire suppression (Clewell 1989).

Managers within therange of wiregrass are cautioned not to confuse wiregrass with similar species when evaluating sites. Hall (1989) notes that other grasses, such as Curtis' dropseed (Sporobol us curtissii ) and pineywoods dropseed (S. junceus), can be confused easily with wiregrass. 


\section{Old Growth Pine}

Presence of many old growth (100+years) or older mature (50+years) native pine trees, forming an open canopy, can indicate a high quality site for many TES. Oldgrowth pine tree indicators are a gnarled, flat top morphology, a slightly widened trunk base, or the presence of RCW cavities. High-quality, Type I sites generally contain multiple age-classes of pines, showing a wide range of diameter at breast height (DBH) classes and regeneration stages (e.g., seedlings, saplings; FNAI 1994b).

\section{Other Indicator Species}

Certain plant species indicate the presence or absence of particular stresses or impacts to a community, and assist in assigning qual ity rankings. Sometimes after degradation, species that are not native to the community invade. Other, native species, may be uncommon in natural situations but adapted to disturbed sites. These species are usually not good competitors under the natural disturbance regime. However, after disturbance removes competing species, they may become common due to prolific seed production and germination, or rapid vegetative reproduction. Conversely, species that are good competitors in natural situations may become poor competitors if the disturbance regime is altered and conditions change. For example, conditions can become unfavorable for dominant native species when an area is fertilized or when fire is suppressed.

This section summarizes availableinformation on potential indicator species, based on reports produced for military installations and communications with knowledgeable personnel. Managers are cautioned that species indicative of disturbance in some parts of their range may not be indicative in other parts. Therefore, managers also should attempt to develop their own set of indicators. Knowledge of such indicators can be used (1) to determine past history of a site, (2) for monitoring purposes to determine if a site is becoming degraded, or (3) to determine whether management practices are having the desired effects.

Clewell (1989) listed wiregrass associates that occurred in undisturbed sites, but were rare or absent in pinelands that developed from agricultural fields. Bracken (Pteridium aquilinum), shiny blueberry, dwarf huckleberry (Gaylussacia dumosa), runner oak, dwarf-live oak, dwarf wax-myrtle (Myrica cerifera var. pusilla), turkey oak, bluejack oak, and saw palmetto are all species native to flatwoods and/or sandhills and listed as being rare or absent on more disturbed sites. 
Provencher et al. (1996) used two approaches to identify species that responded to historical soil disturbances in longleaf pine sandhills at Elgin AFB, in the Florida panhandle: (1) comparison of species densities between six groups of four 200-acre fire suppressed plots that had experienced varying degrees of soil disturbance several decades ago and (2) comparison of understory species densities from four, well-burned plots that were selectively logged 5, 25, 65, and more than 95 years ago. The first approach revealed that Elliot's bluestem (Andropogon gyrans), silver bluestem (A. tenarius), dwarf huckleberry, and Darrow's blueberry (Vaccinium darrowii ) werefound in significantly greater abundance in the least disturbed plots. Arrowfeather (Aristi da purpurascens) and 11 species of low panicums (Dicanthel ium spp.) were the only species showing significantly greater densities in plots with known historical disturbances as a result of land management practices. The second approach, which examined more directly the patterns of species recovery following selective logging, revealed the presence of wiregrass (A. beyrichiana), switchgrass (P. virgatum), narrowleaf silkgrass (Pityopsis grami nifolia), and dwarf huckleberry (i.e., mid- to late-successional species). Species showing a declining trend in abundance following logging were broomsedge, bluestem (Andropogon virginicus), low panicums, slender bluestem (Schizachyrium tenerum), pineywoods dropseed, dog fennel (Eupatorium compositifolium), Florida milk-pea (Galactia floridana), and pineland silkgrass (Pityopsis aspera) (i.e., more early successional species). Surprisingly, Provencher et al. (1996) report that the dominant grass species, little bluestem, exhibited no trend using either approach.

In degraded sandhills at Camp Blanding, FL, dog fennel, blackberry (Rubus spp.), centi pedegrass (E remochol oa ophiuroi des), camphor weed (Heterotheca subaxilaris), and sand pine may be indicators of disturbance. Wild grape (Vitis spp.), greenbriar (Smilax spp.), and grass-leaf golden aster, typical in sandhills at Camp Blanding, exhibited weedy behavior in degraded areas (FNAI and TNC 1995). In North Carolina sandhills, broomsedge, dog fennel (both E upatorium capillifolium and $\mathrm{E}$. compositifolium), several Dichanthelium species and sumac (Rhus spp.) are indicators of severe disturbance (although they can sometimes appear after a hot burn; M. Schafale, pers. comm.).

Species associated with degradation in flatwoods at Eglin AFB were winged sumac (Rhus copallina), blackberry, and rush (J uncus polycephalus). Additional species typical of flatwoods that exhibited weedy behavior in disturbed sites were bushy beardgrass (Andropogon glomeratus), greenbriar, and gallberry. Cogon grass (Imperata cylindrica), an exotic species, has been seen infrequently in degraded flatwoods at Eglin AFB (FNAI 1994b). Sumac and St. J ohn's wort (Hypericum spp.) may beindicators of runoff from fertilization activities at K isatchieN ational F orest, 
LA. The presence of St. J ohn's wort may also indicate erosion from uplands ( $R$. Stewart, pers. comm., 1995).

\section{Structural and Compositional Characteristics}

Accurate accounts of old growth flatwoods and sandhills physiognomy, from sites that have not been degraded by fire suppression or previous land uses, are difficult to find in the literature. Most of the information characterizing these communities is based on historic accounts that often were not quantitative studies. Descriptions of healthy communities can be used by managers for comparison with their communities, to determine current quality, and to obtain parameter values for monitoring and restoration goals. Managers are encouraged to use species lists along with any studies on structure or composition of high-quality communities from their area. More information usually can be obtained through state heritage programs. Structural and compositional attributes of both high-qual ity and degraded communities are provided in the following examples.

\section{Pine Flatwoods}

Penfound and Watkins (1937) studied five virgin pine stands in the Florida Parishes of southeastern Louisiana. All stands werecharacterized by the park-like appearance of longleaf pine trees with a crown cover of around 30 percent, an average height of $33.5 \mathrm{~m}$ ( $110 \mathrm{ft}$ ), and an average DBH of $0.5 \mathrm{~m}$ ( $20 \mathrm{in}$.). All stands were noted for the absence of a shrub layer (although a few occasional species occurred) and the presence of a well-defined herbaceous layer (nearly 100 percent cover). Walker and Peet (1983) reported similar characteristics for pine-wiregrass savannas of the Green Swamp in North Carolina, where the "most extensive and best preserved mesic savannas on the Atlantic coast are located." These savannas have had a long history of regular burning, including prescribed burns on a 1- to 4$\mathrm{yr}$ cycle as a management tool. The 21 sites measured had a sparse pine canopy ( 0 to 150 stems/ha [0 to 61 stems/acre]), a grass-dominated understory, and shrubs to $1.5-\mathrm{m}$ ( $4.9 \mathrm{ft}$ ) tall. Shrub biomass varied from 1 to 15 percent of standing crop size. Bunch grasses grew to $50 \mathrm{~cm}$ (20 in.) in height. Clump size of grasses varied inversely with fire frequency, from 5 - to $15-\mathrm{cm}$ (2- to 5.9-in.) basal diameter in annually burned sites to $35-$ to $40-\mathrm{cm}$ (14- to $16-\mathrm{in}$.) diameter in less frequently burned sites. Grasses contributed up to 70 percent of biomass on all sites. Highquality, Typel flatwoods at Eglin AF B were similar. Tree cover was between 5 and 25 percent, and many trees were old growth or older mature, but the community contained multiple age classes of pines and regeneration stages. 
Groundcover composition of high-quality, Typel, sites varied across the range of the community and with moisture conditions. Threeawn grass (Aristi da virgata), little bluestem, broomsedge, elephant's foot (Elephantopus nudatus), and panic grass (Panicum rhizomatum) were important species in southeastern Louisiana stands (Penfound and Watkins 1937). Wiregrass, Florida dropseed (Sporobolus floridanus), and toothache grass were dominant grasses, and composites (Asteraceae) were the most abundant forbs in flatwoods at Eglin AFB (FNAI 1994b). In mesic flatwoods of the Green Swamp, important hummock-forming graminoids were dropseed (S. teretifolius), cutover muhly (Muhlenbergia expansa), toothache grass, bluestems, and beak rush (Rhynchospora plumosa). Wiregrass occurred, but was not a dominant species. Between the hummocks, characteristic species included a lycopod (Lycopodium carol inianum), beak-rushes (Rhynchospora breviseta and R. chapmannii), theinsectivorous Venus' fly-trap (Dionaea musci pula) and sundew (Drosera capillaris), and many species of composites (Walker and Peet 1983).

Degraded but restorable (Type II) examples of pine flatwoods on Eglin AFB exhibited a canopy that either was characterized by older, widely spaced trees, or younger, densely spaced trees (25 to 50 percent cover). Age structure varied from multi- to even-aged. Percent cover of shrubs ranged from 5 to 75 percent, but was typically between 50 to 75 percent. Shrub height ranged from 0.5- to 5-m (2- to 16-ft) tall, but shrubs usually formed a dense understory less than 2-m (7-ft) tall. The common percent cover class of herbs was between 5 and 25 percent, but cover between 75 and 100 percent was also recorded. These areas may have been fire suppressed or may have experienced changes in vegetation due to alterations in hydrology or physical disturbances to the groundcover and canopy (FNAI 1994b).

\section{Sandhills}

Canopy cover in high-quality, Type I sandhills has been reported between 5 and 25 percent at Camp Blanding (FNAI 1994b; FNAI and TNC 1995) and between 35 to 45 percent at Eglin AFB (Provencher et al. 1996). The canopy was dominated by longleaf pine in xeric sites, and also contained southern red oak (Quercus falcata) in less xeric sites. Tall shrubs and small trees (greater than $2 \mathrm{~m}$ [7 ft]) were sparsely distributed, making up less than 25 percent cover. Trees included turkey oak, sand post oak, sand live oak, and bluejack oak. Shrubs included dwarf huckleberry, licania (Licania michauxii), and legumes (Fabaceae). Wiregrass, little bluestem, silver bluestem, beardgrass, Mohr's threeawn grass (Aristida mohrii), and pineywoods dropseed were the dominant grasses. Several composites and legumes also occurred in the herb layer. 
In high-quality, Typel sandhills of the West Gulf Coastal Plain, largelongleaf pines are dominant, but can co-dominate with shortleaf pine. Understory dominants indude bluejack oak and sand post oak. Woody shrubs may be locally dominant in less frequently burned sites, and include St. Andrew's cross (Hypericum hypericoides), poison oak (R hus toxicodendron), winged sumac, wax myrtle, American beautyberry (Callicarpa americana), sparkleberry (Vaccinium arboreum), and gooseberry (V. stamineum). Dominant perennial grasses include Dicanthelium oligosanthes, little bluestem, slender bluestem, silver bluestem, and pineywoods dropseed. Bracken may be locally abundant in areas of severe burns or past soil disturbance. Herbaceous cover in more xeric areas is usually sparse, with considerable exposed sand and foliose lichen cover, and is characterized by numerous endemic species (Bridges and Orzell 1989).

Degraded but restorable (Type II) sandhills at E glin AFB or Camp Blanding either experienced fire suppression or physical disturbances to groundcover and canopy. The canopy was usually dominated by longleaf pine, but oaks and sand pine may have co-dominated. In some cases, longleaf pine was not a member of the canopy at all. Canopy tree maturity ranged from younger mature to old growth, and the population was made up of mixed aged or even-aged trees. Shrub species (woody species less than $5 \mathrm{~m}$ [16 ft] in height) in xeric sandhills typically ranged between 5 to 25 percent cover, but may have reached 75 percent cover. In less xeric sandhills, shrub cover ranged from 25 to 75 percent. Herbaceous species typically ranged from 5 to 25 percent cover. Degraded sites typically showed evidence of disturbance, such as tree stumps, stump holes, fire breaks, vehicle tracks. Weedy species may have been present, but not to the exclusion of nonweedy natives (FNAI 1994b; FNAI and TNC 1995).

In sandhills of the West Gulf Coastal Plain, sweetgum (Liquidambar styraciflua), flowering dogwood (Cornus florida), and loblolly pine increase in dominance in unburned or previously logged stands (Bridges and Orzell 1989). Stand age structure collected from the Turkey Creek Unit of the Big Thicket National Preserve, TX, showed a canopy dominated by loblolly pine, shortleaf pine, longleaf pine, southern red oak, post oak and hickories (Carya texana and C. tomentosa). Age structure data demonstrated that the oaks and longleaf pine were part of the forest vegetation before large-scale logging began around 1930. Shortleaf and loblolly pine may have become components of the canopy largely after logging (Harcombe et al. 1993). 


\section{Impacts and Management Recommendations}

Thefollowing management information is based on literature review, contacts with experts, and guidelines provided in installation reports. Information on habitats and management for rare plant species was gathered from USF WS Recovery Plans, TNC Element Stewardship Abstracts; J ordan, Wheaton, and Weiher (1995); Godfrey and Wooten (1979, 1981); Kral (1983); Small (1972); and Ward (1979).

\section{Fragmentation and Land-Use Conversion}

\section{General}

Impacts. Natural communities on installations often are fragmented by roads, firebreaks, and drop zones, and are converted for urban uses, military training facilities, pine plantations, wildlife food plots, and borrow pits (Russo et al. 1993, TNC 1995). General effects of fragmentation on TES populations include outright habitat loss, population isolation, changes in community composition duetochanges in competitive interactions between and within species, and changes in predation, parasitism, and herbivory patterns (reviewed in Trame and Tazik 1995).

Fragmentation is likely to impact animal TES that require large, continuous areas of habitat. Fragmentation of pine woodlands leads to increased susceptibility of RCW cavity trees to windthrow (I .J ackson, pers. comm., 1995), and was negatively associated with woodpecker group size in small populations (Conner and Rudolph 1991). Furthermore, RCW need large, old trees for habitat, and they must find a new site if all large trees are occupied or destroyed. Once a site becomes isolated and vacated, it is not recolonized for a long time, because dispersal distances of RCW are normally not greater than about $8 \mathrm{~km}$ (Simberloff 1993). Gopher tortoise populations are not only fragmented by land-use conversion, but individuals inhabiting these fragmented habitats may experience increased nest depredation by species that thrive in fragmented landscapes. For example, Landers, Garner, and McRae (1980) found high predation of gopher tortoise nests in southwestern Georgia by skunks (Mephitis mephitis), raccoons (Procyon lotor), and crows (Corvus 
brachyrhynchos). In Florida and Alabama, tortoises were predated by feral dogs. Landers, Garner, and McRae (1980) al so found several hatchlings destroyed by fire ants (Solenopsis spp.). Highly fragmented pine ecosystems also pose problems for animal species by (1) creating isolated habitat patches too distant from source populations to col onize (e.g., Bachman's sparrows; Dunning 1993) and (2) increased predation and mortality (from automobile traffic) caused by travelling between habitat patches (e.g., fox squirrels, southern hognose snakes, eastern indigo snake [Moler 1992; J ordan, Wheaton, and Weiher 1995]). Manmade barriers also can fragment TES habitats. For example, amphi bians depend on flatwoods for habitat and also on ponds to breed. If fragmentation creates a barrier between the flatwoods and the breeding ponds, the species will be unable to reproduce (A. Weakley, pers. comm., 1995).

Fragmentation in combination with certain land uses al so can cause problems with firemanagement. For example, if natural communities requiring firemanagement are within city limits or are surrounded by housing, prescribed burning may not be feasible because of smoke management problems (A. Weakley, pers. comm., 1995). Similarly, prescribed burning on significant portions of military training lands may be constrained due to the presence of military structures, smoke management issues, or the presence of troops in the field (U.S. Forest Service [USFS] representative, pers. comm., 1995), although this situation varies greatly among locations. Moreover, military training (i.e., occupation sites, assembly areas, tank maneuver areas) can fragment fuel sources (e.g., bunchgrasses) that carry fire over large areas (J ordan, Wheaton, and Weiher 1995) (Figure 4). As a result, many areas are unable to burn as frequently as needed for the maintenance of TES habitat.

Another impact associated with fragmentation is invasion by exotic species. Feral hogs are known to cause extensive damage to longleaf pine forests (see Exotic and Pest Species, p 79). They can travel up to $25 \mathrm{~km}$, so it is likely that small fragments of forest surrounded by land favorable to hogs will be susceptible to major hog damage. Fragmented habitats al so will be more susceptible to invasion by exotic plants (e.g., vines such as kudzu (Pueraria montana) thrive along the edges of forests due to increased sunlight). Other impacts associated with fragmentation include erosion from roadside ditches, alterations in hydrology, and fire suppression.

Management recommendations. Further fragmentation of TES habitat areas should be avoided whenever possible. If such areas (or nearby areas) must be cleared or developed, development should be concentrated in one area, preferably adjacent to areas already developed and not spread throughout natural com- 
munities. This concentration will minimize edge effects caused by fragmentation. Activities that will interrupt TES population processes, or ecosystem processes, should be avoided, or an alternative location for the activity should be sought. For example, avoid fragmentation activities that will interrupt the water flow patterns in high- and intermediate-quality (Type I and II) wetland communities, or create barriers between connected habitats used by a TES species. Simberloff (1993) recommended that forests from which timber is extracted should be managed as part of the matrix supporting the entire ecological community, to avoid effects of fragmentation on species populations.

Managers may wish to restore degraded areas that separate high-quality natural communities, to minimize effects of fragmentation. If restoration efforts are successful, they will result in a less fragmented landscape, which will allow for better management at the landscape level (e.g., Iandscape-level burns), and will allow for the continuation of processes across the landscape. For example, TNC has suggested closing and revegetating 25 percent of the firebreaks on Fort Bragg as an erosion-control measure, which also will increase the average size of each prescribed burn unit (Russo et al. 1993).

Management recommendations also are provided for fragmentation activities that occur or have occurred on installations. These include devel opment of borrow pits, wild life food plots, and plantations. Recommendations regarding natural ecotones, corridors, and military land use also are provided.

\section{Borrow Pits}

Impact. Development of borrow pits involves clearing all vegetation in an area (which can be several ha in size) and removing sand and clay for construction uses. Development of new borrow pits can destroy habitat for TES if they are present, increaseer osion and subsequent runoff, and contributeto fragmentation. However, old borrow pits can become ephemeral ponds and provide habitat for a variety of amphibians, including the rare gopher frog (TNC 1995).

Management recommendations. New borrow pits should not be constructed in Type I or II natural communities that may provide habitat for TES. Existing borrow pits that impact high-quality TES habitats should be restored to prevent erosion, and new pits should be dug in areas where TES are not impacted. Restoration can be accomplished by sloping and contouring the pit walls and seeding them with longleaf pine, or by filling and grassing cuts created by erosion and creating swales to prevent further erosion (Dept. of the Air Force 1993). When borrow pits are being restored, TES protection can beconsidered (LeBlond, F ussell, 
and Braswell 1994a). At Elgin Air Force Base some borrow pits have been rehabilitated toreducesoil erosion runoff intostreams inhabited by theEndangered Okal oosa Darter (E theostoma okal oosae). In addition, it is preferable to revegetate with native species (e.g., wiregrass or other bunchgrasses, as appropriate), because planting non-natives may lead to problems if they become invasive.

\section{Wildlife Food Plots}

Impacts. Wildlifefood plots areessentially community conversions. They are often placed in the forest in areas that were cleared by logging practices (e.g., loading decks).

Management recommendations. Avoid placing wildlife food plots in high- or intermediate-quality communities in which TES management is a priority. Gradual elimination of wildlife food plots that interrupt Type I or II natural communities is recommended as well (TNC 1995). I deally, food plots developed in high-quality natural areas are planted in native species and burned al ong with the adjacent natural community (M. Schafale, pers. comm.). One possibility is to create food plots on old roads scheduled for dosure and revegetation.

\section{Plantations}

Existing Type I natural communities that serve as TES habitat should not be converted to plantations. Plantations that support native groundcover should be considered candidates for restoration if it is important to reduce habitat fragmentation. Groundcover species can be enhanced by thinning the canopy to increase light levels, and burning on a 3-yr rotation. If restoration of longleaf pine is desirable to maintain habitat connectivity for TES, the commercial forestry species can be cut and replaced with longleaf pine, either immediately, gradually, or upon reaching rotation age. The most important factor is minimizing soil disruption and removal of groundcover during removal and replanting. If the plantation is bedded, the decision to level beds must be made on a site-specific basis, according to the current hydrology of the site and the presence of native groundcover species on the raised beds (M. Schafale, pers. comm.).

\section{Natural Ecotones}

Impacts of fragmentation. Natural ecotones are transitory boundaries between ecosystem structures and function (Christman 1995). The preferred habitat of several TES in the longleaf pine-wiregrass ecosystem is in the ecotone between upland communities and adjacent wetlands (see Appendix C). Placement of roads 
and pl owed firebreaks within theecotone degrades habitat for TES and impedes fire from entering the edges of natural wetland communities, allowing shrubs to invade the ecotone (F rost, Walker, and Peet 1986). Plowed firebreaks cause additional damage to hydrology and natural soil processes (Christman 1995).

Management recommendations. Ecotones should not be disturbed in sites for which TES habitat management is the highest goal. Roads and firebreaks that disrupt natural hydrologic and burn patterns in high-quality ecotones that serveas TES habitat should be reduced to the minimum level necessary to accomplish the military mission, with theremaining ecotones being all owed to recover. Roads that transect ecotones can be stabilized or otherwise improved to prevent unnecessary erosion impacts. Fire ditches may be restored to the original grade to restore natural hydrologic patterns (Christman 1995; see Fire and Fire Suppression, $p$ 40).

\section{Use of Corridors To Minimize Impacts of Fragmentation}

Because of habitat fragmentation and the subsequent isolation of area-sensitive wildlife populations, interest has increased in the creation or preservation of corridors that link populations and habitats (Harris 1984; Noss and Harris 1986; Harrison 1992). Corridors often are recommended to facilitate the movement of organisms between habitat patches, increase the amount of habitat available to individuals, increase genetic interchange, allow populations to move or seek refuge in response to environmental changes and natural disasters, and allow individuals to recolonize formerly occupied habitats (Noss 1987; reviewed in Beier and Loe 1992). However, the use of corridors instead of providing large enough habitat patches is not al ways recommended (Simberloff 1993). Several authors have sug-

gested that corridors could increase predation within connected forests because their high concentrations of edge habitat could attract edge-adapted species that would forage within the forests (reviewed in Simberloff 1993). Moreover, corridors may provide avenues for exotic species, parasites, and disease (Simberl off and Cox 1987). The use of narrow corridors by RCW or other TES has not been supported by empirical evidence. Developing corridors wide enough to contain interior-like conditions may be difficult and time consuming, but is clearly preferable over the typical 50- to 100-m wide riparian corridors dominated by edge habitat. Before corridors can be advocated for an ecosystem, additional information needs to be collected on the intended beneficiary species, including movement patterns of dispersing animals and cues used to determine dispersal direction (Harrison 1992). 


\section{Military Land Use}

The use of land for military activities will always be the highest priority on military installations. Areas such as drop zones, multipurpose range complexes, impact areas, and tracked vehicle maneuver areas tend to perpetuate the presence of early successional plant communities whilefragmenting mid- tolater-successional stage communities. Without landscapelevel planning to reduce fragmentation, it is possible that the spatial distribution of habitat disturbance is more detrimental than the nature of any given disturbance. However, planning military activities to be compatible with the spatial habitat requirements of TES is a proactive method for reducing the potential land-use conflict between training and TES. For example, planners may choose to avoid fragmenting a high-quality landscape by situating a new training range in an area that is less valuable ecologically. Training plans and construction projects that minimize habitat degradation, loss, and fragmentation will support more resilient TES populations, and indirectly reduce the population-level significance of local impacts (e.g., alteration of normal behaviors, trampling of individual plants) inherent in military land use.

\section{Fire and Fire Suppression}

Historically, fires resulted from lightning strikes which occurred frequently during the growing season (Abrahamson and Hartnett 1990). In addition, fires have been set by humans for the purpose of hunting since the early aborigines (Abrahamson and Hartnett 1990). Before habitats became fragmented by human activities, fires spread naturally, sometimes burning areas the size of several counties (N oss 1988).

Around 1920, the USFS began promoting active suppression of wildfires (Frost 1993). Meanwhile, winter fire was used for game management in some areas (Abrahamson 1984). These practices continued until recently and had drastic effects on vegetation and community structure. Fire suppression, alteration of the natural fire season, and fragmentation have eliminated the possibility of a natural fire regime in this ecosystem.

Many sandhills and flatwoods on installations show evidence of fire suppression (e.g., FNAI 1994b, FNAI and TNC 1995, TNC 1995, Russo et al. 1993). However, examples of high-quality pine communities on installations today occur in and around impact areas, because these areas have frequent fires resulting from exploding ammunition and flares. Most installations have an active, prescribed burning program as well, so acreages of high-quality areas are expected to increase 
in the future. Table 4 lists activities that can lead to fire suppression in pine flatwoods and sandhills.

Impacts. Fire suppression, logging longleaf pine, planting slash pine outside its natural range or in plantations, and introducing feral hogs (which prefer longleaf pine seedlings over other pine seedlings as a food source) have allowed less firetolerant pines to dominate areas formerly occupied by longleaf pine (Ware, Frost, and Doerr 1993). Slash pine in flatwoods was originally confined to areas that experienced lower fire frequency, but it now dominates other areas in flatwoods. Slash pine, loblolly pine, shortleaf pine, and sand pine (in Florida) have become common in degraded sandhills formerly occupied by longleaf pine, or the pine canopy has been removed altogether and scrub oaks prevail.

Fire suppression contributes to the rapid development of a shrubby understory in flatwoods and sandhills (Figure 5). In sandhills, fire suppression has led to dominance by scrub oaks, although changes are less rapid, especially in xeric sandhills. Fire suppression also leads to the development of a dense canopy (Christensen 1988).

The native groundcover of sandhills and flatwoods disappears in the absence of growing-season fire, as a result of shading by taller individuals and reduced flowering (Clewell 1989; Stout and Marion 1993). Wiregrass, for example, does not normally flower unless the site is burned in spring or summer (Abrahamson and Hartnett 1990). Little bluestem and other bluestem grasses flowered much more conspicuously following growing-season burns than dormant season burns in a North Florida study (Robbins and Myers 1992). Wiregrass, once lost from a community, is not quick to return, as germination is negligible and asexual regeneration occurs only through expansion of existing clumps (Clewell 1989; see Wiregrass restoration). Loss of longleaf pine and wiregrass in flatwoods and sandhills decreases pyrogenicity, because these species havevolatileoils and resins in their needles and blades that hel p carry firethrough the community (N oss 1988).

\section{Management recommendations.}

1. Season and frequency of burn. Little is known concerning the most beneficial frequency and timing of burning for many rare plant species. Ware, Frost, and Doerr (1993) and Stout and Marion (1993) suggested that the natural-fire return interval in longleaf pine-dominated communities is every 1 to 3 years. Research indicated that the optimal burn frequency for endangered rough-leaved loosestrife is every 2 years during the growing season, although burning every 3 years should be sufficient to maintain healthy, sexually and asexually reproducing populations 
(Russo et al. 1993). Populations of endangered American chaffseed are increasing in size in both annually burned areas and in areas burned on a 3-yr rotation at F ort Bragg (Russo et al. 1993). Smooth bog-asphodel (Tofieldia glabra), a Federal species at risk, exhibits greatest seed production 1 to 2 year after a growing season burn (Russo et al. 1993). Current research on Fort Bragg may confirm or refute this assertion (Shipley, pers. comm., 1995). Georgia lead-plant (Amorpha georgiana var. georgiana) may not flower or fruit until 2 years after a burn, suggesting that burning too frequently would prevent sexual reproduction in this species (Russo et al. 1993); this possibility will be evaluated through ongoing monitoring on Fort Bragg (J . Shipley, pers. comm., 1996). Walker and Peet (1983) showed that in Green Swamp annually burned mesic savannas averaged 26 percent more species per $\mathrm{m}^{2}$ (2.4 percent more species per sq ft) than less frequently burned (fire return interval from 2 to 4 years) savanna. Of 46 species that occurred only in annually burned or only in less frequently burned sites, 36 were found in the annually burned type (Walker and Peet 1983). These results suggested that an average fire return interval of every 2 yrs may best suit species in this community, and that burning too frequently is less damaging than not burning frequently enough. The recommendation to burn at an interval of 1 to 3 years appears to be consistent with the recovery plans for Cooley's meadowrue (Thal actricum cooleyi; USFWS 1994), and rough-leaved loosestrife (USFWS 1993a). In contrast, the recovery plan for Chapman's rhododendron recommends prescribed burning with a hot fire every 4 to 5 years (USFWS 1983).

Compared tolonger firereturn intervals, burning frequently has advantages for fire managers in that the fire is cooler (because fuel loads are low), moves faster, and creates less smoke (J . Murian, pers. comm., 1995). Prescribed burns in Louisiana in both November and May led to soil movement rates that were twice that seen on unburned control sites (Haywood, Martin, and Novosad 1995). The recommendation to burn vegetation on highly erodi ble soils or sloped lands must be balanced with evidence that such burns may lead to erosion and sedimentation of lower areas such as gullies. A longer burn interval may be best for sites where erosion is a concern.

A fire return interval of 1 to 3 years appears compatible with native animal species inhabiting this plant community. However, when RCW are present on an installation, specific guidelines prescribe burning in the longl eaf pine communities (Dept. of the Army 1996). The RCW recovery strategy for the southeastern U nited States emphasizes growing-season prescribed fires for midstory hardwood control on a 3- to 5-yr cycle (Krusac and Dabney 1994), although Army-wide management guidelines call for prescribed burns at least every 3 years with intervals not to exceed 5 years (Dept. of the Army 1996). Short burning intervals (i.e., $\leq 3 \mathrm{yr}$ ) also 
arerecommended for Bachman's sparrows, which greatly benefit from management for RCW (Dunning 1993). Based on limited information available for other animal TES inhabiting this community, frequent burning appears compatible with the maintenance or enhancement of their habitat.

Few studies have been conducted to assess whether early or late growing season burns aremost beneficial to the longleaf pinecommunity (Platt et al. 1989, Robbins and Myers 1992). For plant species for which this information is available and for this community as a whole, burning is recommended during the growing season (usually early in the growing season) to maintain community structureand habitat for plant TES, and in many cases to stimulate flowering and fruiting ( $)$ ohnson 1993a, 1993b; LeBlond, Fussell, and Braswell 1994a, 1994b, reviewed in Robbins and Myers 1992; Russo et al. 1993; Smith 1994). In addition, early growing-season burns are recommended over late growing-season burns for the following reasons: (1) in Florida, lightning fires are most common in early summer, and the largest land area is burned naturally during late spring and early summer, (2) studies suggest that early growing-season burns are more favorable to growth and survival of longleaf pine seedlings and saplings than late growing season burns, which may be because they help reduce infection rate of brown spot needle blight (Scirrhia acicola) (a fungus that affects the seedlings during the grass stage), (3) early growing season fires aremore detrimental to hardwoods, which competewith pines for establishment (reviewed in Robbins and Myers 1992), and (4) growing season burns may cause less soil loss than winter burning, since rapid recovery of vegetation is possible, and nutrients released by the fire may be quickly incorporated into growing plant tissues (Haywood, Martin, and Novosad 1995). LeBlond, Fussell, and Braswell (1994a, 1994b) suggested that burns be conducted primarily, but not exclusively, between May and J uly at Marine Corps Base (MCB) Camp Lejeune, NC.

Managers may wish to avoid conducting burns repeatedly during flowering times of rare plant species occurring in their sites (Russo et al. 1993; Smith 1994). However, for many rare plant species, the degreeto which their populations rely on sexual versus vegetative reproduction is not known. In addition, some species, such as Cooley's meadowrue, have been observed to resprout and flower later in the season if burned during the early growing season (USFWS 1994).

Timing of prescribed fire during the growing season may depend on specific management objectives and animal TES present on the installation. Although growing season burns arehighly desirablefor maintenance of sandhill communities, and are recommended for most animal TES in these communities, growing-season fires have been discouraged for some TES. Zappalorti (1994) pointed out that 
growing-season fires may adversely impact pine snakes and suggested that winter fires (occurring whilesnakes are in hibernacula) would avoid any potential impacts. Indigo snakes also are particularly active during spring, moving from sandhills to more mesic areas. If gopher frogs are present, early-growing season burns may interfere with movements to and from breeding ponds. However, many of these problems can be avoided by delaying prescribed fires until later in the growing season (i.e., May/J une), which would allow many species to complete breeding and movements out of the community (A. Braswell, pers. comm., 1996).

Regular fire frequency is unnatural at any given site. Varying fire frequency among burn units, or among patches within large units, may be necessary to maintain a variety of TES. Creating a mosaic of vegetation conditions should contribute to species diversity (LeBlond et al. 1994a). Therefore, burning more irregularly may be necessary (LeBlond et al. 1994a; Robbins and Myers 1992; Glitzenstein et al. 1990). Burning at different times within the growing season, as noted above, may be needed to maintain different species (Platt, Glitzenstein, and Streng 1989).

In areas that have been fire suppressed for long periods of time, reduction of fuel loads may be necessary so that summer fires do not burn hot enough to damage crowns of adult pine trees. In these cases, winter-season burns prior to the initiation of growing-season burns are recommended to reduce fuel loads (Dept. of the Air Force 1993; Robbins and Myers 1992). However, management recommendations for Fort Stewart, GA, discouraged winter burns in areas known to harbor populations of rare amphibians; burns in theseareas should beconducted prior to October, when newts and salamanders actively begin moving into ponds (TNC 1995). When it is necessary to burn fire-suppressed areas with high fuel loads, low intensity burns can be conducted during the growing season, if fuel moistures are high (TNC 1995). In addition, burning these sites on short fire rotations for the first several years is recommended until the vegetation and fuel loads have been reduced (Smith 1994). In some cases, mechanical reduction of fuels may be necessary (see Restoration Activities, Midstory Reduction).

These recommendations are based on current knowledge. However, because there is little information on the frequency and timing of burning that best suits many species, and because conditions vary from site to site, managers should monitor the effects of their burning schedules on elements of concern (e.g., TES, keystone species, structural elements). They should be willing to change their management schedules based on response of these elements to fire frequency and timing, and also on new information as it becomes available. For example, site-specific information regarding presence of specific TES and timing of breeding and 
movements of animal TES may allow managers to delay initiation of prescribed fires until later in the growing season.

2. Determination of conditions prior to prescribing fire Relative humidity and temperature are monitored before a burn to calculate fire-fuel moisture. Higher moistures generally result in a cooler fire. Soil moisture may be recorded as well, and soil moisture thresholds for specific habitats have been determined from previous monitoring. These readings can be used to predict whether the habitat will burn and whether it will burn too intensely (i.e., causing crown fires, girdling trees, or destroying organic layers of soil (J . Segar, pers. comm., 1996).

3. Monitoring/ mapping for prescribed fire. During a prescribed burn a running log should be kept that includes times for each entry. The log should include such information as personnel attending the burn, methods and equipment used, progress of the fire, any problems and how they were solved, general notes on the fire, and wind speed and direction (J . Segar, pers. comm., 1996).

Creating a map showing the extent of a burn is useful for documenting the fire history for any part of an area to be monitored. Overlays of fire maps have been used to delimit areas of various fire histories, and these have corresponded to differences in present vegetation observed in the field as well as with satellite reflectance images (K. Robertson, pers. comm., 1996). I deally, a map should identify areas that have burned with various intensities (e.g., areas where the soil was scorched or the fire became a crown fire). Where there are sufficient landmarks, such as nearby roads, field mapping may be done by running transects from known points to points identifying the extent of the burn. Notes may betaken on previously prepared maps, such as the U.S. Geological Survey (USGS) 7.5 minute topographic quadrangles. Portable global positioning systems (GPS) are useful, especially where landmarks are not available (J . Segar, pers. comm., 1996).

The extent of a burn may also be mapped from the air, usually from a helicopter. This aerial mapping is advantageous for areas not easily accessible on the ground. The disadvantage of this method is a reduction in the ability to assess the immediate effect of the fire on the habitat and intensity of the burn. When prescribed fires are ignited from the air, mapping can be accomplished during the same flight, in most circumstances (J . Segar, pers. comm., 1996).

Accurate measurements of the intensity of a burn may be made by using pellets designed to melt at various temperatures.These pellets available from various forestry supply companies, generally are not used, except when fairly precise 
monitoring is required (e.g., for experiments investigating the survivorship of certain plant species).

4. Fire prevention. Natural fire breaks (e.g., wetlands) should be used whenever possible to contain the fire. Fire should be allowed to spread through the ecotone and into edges of adjacent wetland communities (LeBlond, F ussell, and Braswell 1994a, 1994b; Russo et al. 1993). For example, fires should be allowed to burn downslope through the herbaceous ecotone and into pocosin edges.

If it is necessary to prevent the spread of fires into adjacent communities, existing trails, woods, and roads should becleared and used as control lines if possible(Dept. of theAir F orce 1993). Otherwise, fire can be controlled using spot fires, hand lines, chemical fire retardants, and, as a last alternative, plowlines.

One method of producing spot fires involves dropping plastic containers (often referred to as pingpong balls) from a helicopter. These balls, filled with potassium permanganate combined with antifreeze, will land and set small fires every 15 to $150 \mathrm{~m}$ ( 49 to $492 \mathrm{ft}$ ). These fires will burn together before the fire becomes very hot. This technique, which is important when access or weather conditions constrain burn opportunities (Fort Polk, anonymous reviewer, 13 August 1996), is used often in conjunction with a natural or existing firebreak. Managers at Fort Stewart, GA, have used this method instead of fire plowlines to maintain a cool groundfire ( $T$. Beaty, pers. comm., 1995). However, it has been suggested (J . J ackson, pers. comm., 1995) that the burn produced using this method may not be appropriate for TES management, because the burn can be uniform and even. Natural or groundignited fires move slowly in some areas, and fast in others, providing for a mosaic of hot and cool burn areas. J . Murian (pers. comm., 1995) has made suggestions for planning prescribed fires to create desired effects. To promote a mosaic burn, managers should burn in wet conditions and place fires close together or far apart depending on whether they desire cool or hot burns. Product labels generally recommend that managers use 5 to 7 balls/acre ( 12 to $17 /$ ha), but managers at TNC have doubled the number of balls per acre and burned when fuels were damp to achieve a cool, patchy burn.

Managers can useclass A foams to createfirebreaks without vegetation destruction. Class $A$ foams act as wetting agents and reduce the surface tension of water. Users at Eglin AFB found that some class A foams appeared to be environmentally friendly (L. Ballard, pers. comm., 1994). However, there is concern that the surfactant properties in class A foams may break down the cutins in plants over time (L. Ballard, pers. comm., 1995). Studies have shown that foam use may also affect plant species' diversity (D. Larson, pers. comm., 1995). Other research has 
shown negative effects of foams on aquatic organisms, even at low concentrations (S. Hamilton, pers. comm., 1995). When no danger of input into aquatic systems exists, foams may be the best alternative to using plowlines when natural fire breaks do not occur. However, because so little is known about effects on el ements of concern, managers should monitor effects of foam use (see Appendix $E$ for more information).

When it is necessary to control fire using plowlines, existing lines should be reused whenever possible to minimize additional soil disturbances (Dept. of the Air Force 1993). If new fire plowlines must be developed, they should not be located in ecotonal areas or where TES occur (Dept. of the Air Force 1993; LeBlond, F ussell, and Braswell. 1994a; Russo et al. 1993). It is important not to place fire plowlines in the ecotone, because ecotones provide habitat for several TES. Plowlines should not be placed immediately upland from the ecotone either, becausethis will prevent the ecotonefrom burning (LeBlond, F ussell, and Braswell 1994a, 1994b). Plowlines also should not be placed around cypress/tupelo/blackgum (Nyssa sylvatica var. biflora) ponds because they will alter hydrology and the reproductive success of amphibians that use the ponds (TNC 1995). Therefore, managers should determine optimal placement of plowlines using careful planning, to avoid potential impacts to hydrology and TES populations when possible. Managers should excavate only the minimum number of plowlines necessary to contain the fire, and only to the minimum depth needed to control it (Dept. of theAir F orce 1993). Disked plowlines should be used instead of V-bladelines whenever possible (G. Tanner, pers. comm.). To minimize erosion, plowlines should be oriented along contours, and should not bisect or tie into waterways or riparian zones, or be placed downhill at right angles to steep slopes (Dept. of the Air F orce 1993).

Plowlines that may erode after a fire should be rehabilitated using native vegetation (Dept. of the Air Force 1993) and indigenous soil (LeBlond, Fussell,and Braswell 1994a). Abandoned plowlines may also be rehabilitated in the same way (LeBlond, Fussell, and Braswell. 1994a).

\section{Alteration of Hydrology}

\section{General}

Impacts. Altered hydrology is not likely to bethe primary concern for plants within the well-drained areas in sandhills and drier flatwoods, but can lead to significant impacts in wet flatwoods. Furthermore, many rare plant TES associated with sandhills and flatwoods occur at the ecotone between drier communities and 
adjacent wetlands (e.g., sandhill seeps, pocosins; see Appendix C). Alterations in hydrology cl ose to or within the ecotones are likely to affect these plant TES. Many amphibians use ephemeral depressional wetlands within sandhills and flatwoods, and would also be affected by hydrological alterations. Altered hydrology in upland communities can lead also to erosion and deposition of silt in lower-lying communities, raising the soil surface and directly impacting plants (Brown, Stone, and Carlisle 1990).

Altered hydrology is likely to have community-level effects on wetter flatwoods communities and wetland inclusions within them (e.g., flatwoods ponds). Wet pine flatwoods often have an organic or clay hardpan near the surface, causing water from rainfall to remain on the surface instead of percolating through the soil. The water table is bel ow the hardpan, and, in extreme cases, the hardpan restricts root growth (Abrahamson and Hartnett 1990). As a result, wet pine flatwoods can have saturated soils with standing water in the winter and early spring when transpiration is low, and dry soils during the growing season from increased transpiration and lack of water movement upward through the subsurface hardpan (Martin 1992a-e; Abrahamson and Hartnett 1990). Flatwoods plants are shallow rooted, presumably because a water table close to the surface restricts rooting depths. When the water table drops, these shallow-rooted plants are likely to experience drought stress (Myers 1990).

Altered hydrology in flatwoods and sandhills is also likely to affect hydrology in adjacent communities. Effects of ditches and canals can extend far beyond the communities for which they were intended, lowering the maximum height and duration of the soil water tables on nearby lands. Roadside ditches quickly drain the water in pine flatwoods after heavy rains, inducing greater peak flows into the streams and lowlands where the water is discharged. Table 5 lists activities that lead to alteration of hydrology.

1. Plants. In wetland communities, slight differences in elevation can result in different environmental conditions for establishing plants. Lower-lying areas may range from saturated to moist year-round, while elevated areas dry out in the summer. Plants occurring within these communities can have narrow environmental tolerances and will be affected directly by slight alterations in hydrology. Venus flytrap, a Federally listed species at risk, serves as an example. In the sandhills region, this species is limited to soils having a high water table, an organic hardpan usually not more than $60 \mathrm{~cm}$ (24 in.) below the surface, and a pH range of 3.9 to 4.5 (Roberts and Oosting 1958). On Fort Bragg, the Venus flytrap requires soils that are wet to moist most of the year and cannot survive in areas that become too dry. In addition, it does not typically occur in sites that are semi- 
permanently or permanently flooded. For these reasons and because this species also requires the high light conditions of open areas, the Venus flytrap seldom occurs outside of ecotones adjacent to sandhills, pine flatwoods, and pocosins (Russo et al. 1993). Normally, these ecotones are moist year-round, but changes in hydrology can lead to either drying out or to semi-permanent or permanent saturation, which will eliminate habitat for Venus flytrap and other sensitive species requiring similar conditions (e.g., rough-leaved loosestrife, savanna cowbane (Oxypolis ternata), pale beaksedge (Rhynchospora pallida), Carolina goldenrod (Solidago pulchra), and smooth bog-asphodel; Russo et al. 1993).

Herbaceous species also can be impacted indirectly by changes in hydrology, when these alterations create better conditions for competing species. For example, planted slash pine and understory shrubs growing on wet, phosphorous-deficient soil can have much higher growth rates in the vicinity of roadside ditches, because in addition to draining water from the road, the ditches drain water from within the community (10 to 30 m [33 to 98 ft]; Brown, Stone, and Carlisle 1990). Higher growth rates of slash pine and shrubs reduce survival and growth of herbaceous species through shading (Brown, Stone, and Carlisle 1990).

2. Animals. Altered hydrology in and adjacent to pine flatwoods is likely to significantly impact amphibian TES populations. Both gopher frogs and flatwoods salamanders breed in ephemeral depressional wetlands in or adjacent to pine flatwoods and sandhills. Ditching or berming of small, isolated pond-cypress wetlands, a common practice when establishing slash pine plantations on mesic sites, results in lowered water levels or shortened hydroperiods (Marois and E wel 1983). These hydrologic perturbations could prevent successful flatwoods salamander reproduction by preventing egg inundation or stranding larvae before they are capable of metamorphosis (Palis 1996). Altered hydrology, in association with fire exclusion, results in a shift in dominance from pond-cypress to broad-leaved hardwoods, which reduce herbaceous groundcover vegetation through shading (Marois and Ewel 1983). This reduction may be detrimental to flatwoods salamanders, since larvae take shelter in herbaceous vegetation during the day (Palis 1996). Ephemeral pond-cypress depressions are sometimes converted into permanent water bodies, rendering them unsuitable for flatwoods salamander reproduction (Palis 1996).

Management recommendations. The majority of the vascular plant species listed in Appendix C are listed in the National List of Plant Species that Occur in Wetlands: Southeast (Region 2) as being either obligate wetland (designated by "OBL"; estimated probability $>99$ percent) or facultative wetland (designated by "FACW"; estimated probability 67 to 99 percent) species (Reed 1988). Thus, the 
vascular plant species almost always occur in wetlands and will be affected by activities that alter hydrology. Therefore, minimize activities that will alter hydrology in wetlands supporting TES plants (especially in Type I and II sites). These activities include draining, ditching, filling, damming, and creation of fire plowlines, roads, and new trails (Russo et al. 1993, USFWS 1983).

Activities that create deep ruts (e.g., off-road vehicle use) through "boggy" communities within or adjacent to flatwoods or sandhills can damage the entire bog community, and these activities should be avoided altogether within boggy areas and the adjacent buffer zones. For hillside seeps, the area extending to the top of the hill should be protected as the potential watershed, as should the area extending to the drain below the bog. On broad, shallow slopes, the outer buffer boundary should extend to at least $61 \mathrm{~m}$ (200 ft) beyond the edge of the active seeps. Otherwise, the immediate surroundings of the bog should be protected, and the general ruleis to protect the boundary extending $30.5 \mathrm{~m}$ (100 ft) in all directions from the edge of the active seep (Platt et al. 1990).

Existing roads, trails, and fire plowlines that disrupt surface or subsurface hydrology should be improved or modified to restore water flow patterns (see Fire and Fire Suppression, p 40; Russo et al. 1993). In areas where restricted water flow is directly threatening endangered species' viability, serious consideration should be given to the abandonment of roads, trails, and plowlines, followed by restoration to original topography and revegetation with native species. Plowlines or gullies that channel water should be blocked or regraded (M. Schafale, pers. comm. 1994). When trail, boardwalk, or road construction is necessary, these projects should minimize hydrological or physical damage to the community (Dept. of the Air Force 1993; Russo et al. 1993). When fire plowlines must be constructed, lowest impact methods should be used (see Fire and Fire Suppression, p 40). LeBlond, F ussell, and Braswell (1994a) have provided several recommendations for construction of roadbeds to avoid disrupting hydrology:

Roadbeds that cross streams or are adjacent to wetland basins can result in erosion and siltation within the wetland. It is recommended that erosion be prevented at stream crossings, and that roadbeds not be constructed adjacent to wetland basins. Road fills in wetlands should have adequate culverts to avoid impounding water. Where road runoff is channelized, it is recommended that the runoff not be directed into streams or wetland basins. In areas where sheet flow predominates, roads should [be constructed in such a way that] channelizing the flow [is avoided]. Road ditches should be constructed in a manner to prevent additional drainage of water off of wetland sites. Roads 
should cross streams perpendicularly to minimize damage to thestream and its floodplain.

These recommendations appear reasonable for protecting hydrology of wetlands within the southern pine woodlands ecosystem. However, Brown, Stone, and Carlisle (1990) cautioned that culverts only limit depth of surface water accumulation and seldom prevent impounding of water. In all cases, water movement throughout the local watershed should be examined before initiating projects that may alter hydrology, and impacts of activities on hydrology should be monitored.

\section{Groundcover Disturbances}

\section{Introduction}

Maintaining the integrity of the groundcover in these communities is important because (1) most plant TES are herbaceous species associated with native ground cover (see Appendix C; Hardin and White 1989), (2) animal TES and other sensitive animal species depend on native groundcover for habitat (e.g., flatwoods salamander, tiger salamander [Ambystoma tigrinum], striped newt, and pine barrens treefrog [Hyla andersonii] all depend on wiregrass-dominated environments; [Glitzenstein et al. 1993]), and (3) an intact groundcover is crucial for the spread of fire (Christensen 1981; Clewell 1989; Watson 1986).

Excluding land conversion, most impacts to groundcover species in sandhills and flatwoods are indirect and result from alterations in fire regime or hydrology. Direct impacts discussed here are those that physically destroy plants growing aboveground and may also churn up soil. They include activities that break off parts of plants and those that uproot entire plants. Groundcover-disturbing activities in flatwoods and sandhills include plowline creation (see Fire and Fire Suppression, p 40), wild ifefoodpl ot creation (seeFragmentation and L and-Use Conversion, p 35), borrow pit creation (see Fragmentation and Land-Use Conversion, $p$ 35), pinestraw raking, intensive forestry activities (including mechanical sitepreparation), pine-beetlecontrol activities, off-road vehicleuse, feral hog-rooting (see Exotic and Pest Species, p 79), grazing (see Feral Hogs, p 80), trampling, and mechanized and nonmechanized military training. 


\section{Wiregrass, Other Bunchgrasses, and TES}

Wiregrass is the dominant groundcover species in longleaf pine communities east of eastern Mississippi (Peet 1993) (Figure 7). This species is easily uprooted, and densities are reduced by practices that seem harmless. Several authors have noted that wiregrass does not readily return to sites once it is eliminated. It is often absent for 30 or more years since the last major soil disturbance (reviewed in Clewell 1989; Provencher et al. 1996). F or these reasons and because wiregrass is a keystone species in this community, evaluation of impacts to groundcover is often in reference to reduction in wiregrass dominance.

However, impacts to other species which carry fire in pinelands, including threeawn (Aristida rhizomorpha), muhly, bluestems, panic-grasses, and Paspalums (Paspalum spp.; reviewed in Duever 1989), should also be evaluated (Provencher et al. 1996). Until more information is available, the value of these other species of bunchgrasses as fuel for landscape-level prescribed burns should not be underestimated. These groundcover species should be conserved just as vigorously as wiregrass species in the ecosystems in which they naturally replace wiregrass as the dominant groundcover.

Little research-based information is available on how groundcover disturbances affect plant TES populations. Element stewardship abstracts on individual species (TNC) stated that spring-flowering goldenrod (Solidago verna) and Pickering's morning glory (Stylisma pickeringii var. pickeringii) are commonly observed in disturbed sites, suggesting populations of these species may not be negatively impacted by groundcover disturbances. Pickering's morning glory produces hundreds of flowers and capsules, and it appears that many seeds germinate soon after falling. It occurs in sandhills with little competing vegetation and litter and in a number of disturbed habitats. Seedlings have been observed in areas cleared

a few months earlier. Spring-flowering goldenrod occurs in a variety of habitats throughout its range, and a number of occurrences are located along moist roadsides, ditches, and powerline rights-of-way. Conversely, sandhills milk-vetch (Astragalus michauxii) may be very susceptible to groundcover disturbances, because (1) individuals are not known to colonize disturbed sites, (2) the species appears to havea narrow habitat range (xerictodry-mesic sandhills), and (3) plants typically occur in small numbers. Few seedlings of sandhills milk-vetch have been seen in the field. The bulk of the populations occur on Fort Bragg and Camp Mackall, NC (reviews in Russo et al. 1993).

A few generalizations can be made regarding impacts of groundcover-disturbing activities to rare plant populations in flatwoods and sandhills. As a general rule, 
activities that affect only aboveground growing parts of some individuals (and do not turn up the soil) should not be detrimental toTES populations. This conclusion is because most plants in the longleaf pine community are perennials adapted to frequent fire (e.g., meristems protected near ground by insulating tissues, fireinduced flowering and seed production, and basal sprouting capabilities). Activities that uproot several plants or disturb the soil will cause declines in population sizes of somespecies. More robust forms may exhibit greater tol erancefor soil-disturbing activities. Species that have a geographically narrow range are at the most risk from soil disturbances because a single action could negatively impact a large portion of the population (Walker 1993).

\section{Pinestraw Harvest}

Impacts. Foresters increasingly are promoting pine-straw harvest as a way to increase profit from managed pine lands now that longer rotations are needed for RCW management (Roise, Chung, and Lancia 1991). Long-term experimental studies on effects of mechanized pinestraw raking have not been conducted, but comparisons of species diversity in plots that previously had been raked with plots that had never been raked suggested that long-term raking is correlated with a notable decline in species richness (13 to 40 species of plants in previously raked plots, 65 to 130 species in unraked plots; Schafale and Weakley 1990). Experimental studies of short-term effects ( 1.5 years of mechanized raking for one to four times during that period) showed that raking caused greater losses of pine seedlings, compared with controls. Losses were greater in plots that were raked more frequently. However, since losses also occur in controls, longer studies are needed to determine whether fewer seedlings survive to the sapling stage in raked plots as compared to controls (Kelly, pers. comm., 1996). Kelly also found that communities responded differently toraking, especially in terms of species richness. When final values were compared to initial values, richness dedined in the controls (plots not raked) in all community types (mesic savanna, wet savanna, xeric pinescrub oak woodland). Frequent raking in xeric pine-scrub oak woodland resulted in a greater decline in richness on the $1 \mathrm{~m}^{2}$ scale, compared to controls. Richness in mesic savanna declined less in frequently raked plots than in the controls. In the dry savanna, species richness actually increased in the frequently raked plots. Kelly (1996) found that, in some instances, raking caused greater turnover in species composition. Changes were brought about by the replacement of some species with species that were al ready present el sewhere in the community. These changes suggest that raking affects community composition in the short term. In addition to longer term experimental studies, studies that address effects of raking on rare species are needed. 
Researchers have cautioned that mechanized pinestraw raking may have severe impacts on the wiregrass groundcover and on diversity in the community. Tires and rakes can dig into the soil during harvesting. Intensive (annually or biennially) mechanized pinestraw harvesting can destroy ground-layer herbs and longleaf pine seedlings, concentrate pine seeds into unnaturally high densities, cause or accelerate erosion, and influence fire dynamics (Russo et al. 1993; Schafale and Weakley 1990). At F ort Bragg pine seedlings have been observed germinating in dense rows that were created by raking, suggesting that raking can change regeneration patterns (E. H offman, pers. comm., 1996). A researcher at Fort Bragg has found that sandhills pyxie moss (Pyxidanthera barbulata var. brevifolia), a Federal candidate species, became uprooted during raking. Other species observed in the raking bales at Fort Bragg were baptisias (Baptisia spp.) and tephrosias (Tephrosia spp.; E. Hoffman, pers. comm., 1996). Kelly (pers. comm., 1995) observed that some wiregrass was uprooted by raking. During wet soil conditions, plants seemed more susceptible to being uprooted than when soil conditions were drier (Kelly, pers. comm., 1996).

Management recommendations. No pinestraw raking is recommended in Type I pine communities that harbor plant TES. Frequent raking reduces longleaf pine regeneration, alters species composition, and removes fuel that may be necessary to carry a fire throughout the community.

Until more information becomes available on the long-term effects of intensive raking, raking should not occur at all, or occur only occasionally to semi-frequently in Type II sites (a frequency of 4 to 6 years is recommended by Russo et al. [1993]). Frequency should be determined by the amount of time needed for fuel levels to build up between raking, and for recovery of rare species populations (and native dominants such as wiregrass) to predisturbance size and structure. If possible, raked sites should be burned following a year's rest (M. Schafale, pers. comm., 1994). If raking is allowed to occur in Type I sites, it should be manual rather than mechanized. Only the current year's straw should be removed, without disturbing the decomposing duff layer (G. Tanner, pers. comm., 1996). Pinestraw harvesters should be educated on thelocations of sensitivespecies or features, to avoid adverse impacts to TES or their habitats (Russo et al. 1993). Kelly (pers. comm., 1995) also recommended the following:

- Avoid raking during the growing season. Harvest straw during late autumn, winter, and early spring when the understory vegetation is dormant. This timing will remove less live vegetation than raking during other times of the year, 
- $\quad$ Avoid raking when heavy dew is present or when the vegetation is wet from rainfall. More vegetation is removed under these conditions, and rutting may occur when heavy equipment is used on wet soil,

- $\quad$ Avoid raking in heavily vegetated areas; they may support more rare plant species. Alternatively, more live vegetation can be removed from these areas.

Sufficient measures should betaken at all sites where pinestraw harvesting occurs to assure that it does not lead to destructive soil erosion problems or interfere with the ability to execute prescribed burns (Russo et al. 1993). Finally, managers should monitor the long-term effects of raking on wiregrass and rare species populations. Intensive, mechanized pinestraw raking may be appropriate on degraded sites that support longleaf pine, but lack nativegroundcover (Type III and IV sites). These degraded areas may include old field sites, abandoned training areas, bivouac areas, and cantonment areas. Fort Polk, for example, only allows pinestraw raking in cantonment areas (Fort Polk anonymous reviewer, 13 August 1997). Managers may wish to consider replanting severely degraded areas with longleaf pine so that these areas can serve as pinestraw harvesting sites in the future (Russo et al. 1993).

\section{Mechanized Harvest Operations}

Impacts. Mechanized timber harvesting operations may disturb thesoil (Figure 8). Mechanical methods include use of rubber-tired skidders for removal of fallen trees toloading decks, or use of rubber-tired feller bunchers. Rubber-tired machinery can cause considerable site disturbance, including churning of the soil due to skidding and tire action, followed by mortality of shallow-rooted grasses and forbs. Rubbertired machinery also can damage roots and tree seedlings, increasing their mortality (reviewed in Provencher et al. 1996). However, careful use of some maneuverable, lightweight, rubber-tired vehicles (e.g., feller-bunchers) on dry soils may have negligible effects on groundcover (M. Harper and A. Trame, pers. obs., 1996).

Reisinger, Simmons, and Pope (1988) reviewed the impacts of timber harvesting on soil properties in the South. This review compares percent soil disturbance from different harvesting methods:

Dickerson (1968) reported 21 percent of soil on a clearcut stand was disturbed (bared, rutted and compacted) compared to 14 percent for an area selectively cut. He also found twice as much severely disturbed soil on the clearcut operation. In a 1977 study on effects of [harvest] techniques on soil properties 
in northern hardwoods, soil disturbance averaged 17 percent in selection cut [areas], and 28 percent in strip and patch clearcut areas (Nyland et al. 1977). Soil compaction in the disturbed areas did not vary significantly between treatments. On level terrain, Burger (1983) reported that a greater percentage of the total area is driven over at least once during clearcutting operations. In Alabama, King and Haines (1979) found little soil disturbance and no tire rutting after a mechanical thinning of a slash pine plantation. Low soil moisture content (13 percent) and a surface layer of tops and branches lessened soil compaction during thinning.

More soil disturbance was associated with clearcuts than with selective cutting or thinning (Reisinger et al. 1988). Clearcuts also can have negative effects on adjacent wetlands, especially when clearcutting leads to increased runoff and erosion. Clearcuts are often in large blocks, usually ranging from 30 to 100 ha (74 to 247 acres). The fragmentation caused by clearcutting is unnatural and may pose problems for RCWs and other animals (Glitzenstein et al. 1993). Clearcutting in mature longleaf pine stands eliminates most advance reproduction, and a narrow range of seed dispersal distances reduces the seeding of the clearcut from adjacent stands. Thus, clearcutting a longleaf pine stand, except in a stand well-stocked with advance reproduction, will result in the need for artificial regeneration (Boyer 1993). Finally, even if TES can tolerate timber harvest from clearcutting, future management should ensure that a dense stand does not develop after planting, as this may create too much shade for rare and TES species (Walker 1993).

Sel ective logging causes severe soil disturbance in loading-deck clearings and some disturbance along skid trails (M. Harper and A. Trame, pers. obs., 1996). Observation of selective logging operations in subxeric sandhills in North Carolina revealed that areas used as loading decks, about 1 ha (2.47 acres) in size, are subjected to groundcover disturbances (Figure 9). Following logging operations, wildlife forage species often are planted in these areas to lessen potential erosion problems, which leads to conversion of the original, natural community. Alongskid trails, although groundcover species were disturbed immediately after the logging operations, some wiregrass remained intact and the vegetation along the trails appeared to be regenerating over time (groundcover regenerated after approximately 5 years) (Figure 10). However, recovery may take much longer in xeric sandhills. In such communities at Eglin AF B studies showed that over 50 years of recovery time were needed for groundcover to return to predisturbance composition after logging operations (Provencher et al. 1996).

\footnotetext{
* But note that the added vegetation would be harmful to native groundcover if not burned soon after the harvest operation was completed (M. Schafale, pers. comm., 1994).
} 
Aerial logging and some cable systems cause less soil disturbance than groundlogging systems, because fewer roads are required and machine/log contact to the soil is minimized (reviewed in Reisinger et al. 1988). However, these systems are generally used on steep terrain, and using them may not be economically practical in flatwoods and sandhills (Reilly, pers. comm., 1996).

Soil disturbance during harvest can be minimized if harvesting is done when soils are dry. Moehring and Rawls (1970) studied impacts of harvesting on wet and dry soils and found that wet-weather logging caused morecompaction than dry-weather logging, and reduced growth of pines. Wet-weather logging also caused puddling and created deep ruts.

A practice related to mechanical harvest operations is the removal of resin-soaked stumps (principally longleaf pine) for "lighter-wood" or "fatwood" operations. This practice may reduce habitat for the multitude of organisms using old stumps (Palis, pers. comm.), thus contributing to a dedine in biodiversity. Because pines typically are cut on shorter rotations now, fewer stumps tend to reach the latter stages of senescence, providing less habitat. Thus, conservation of "old-growth stumps" should be considered in future forest management decisions.

Management recommendations. High-quality (Type I) flatwoods and sandhills sites that are important TES habitat should not be clearcut or subjected to soil disturbances associated with the use of heavy equipment. Removing canopy trees with hand-held chainsaws can bea low-disturbance method to restore high-quality sites that have developed a dense canopy after years of fire suppression. If this is not feasible, careful use of lightweight, maneuverable, rubber-tired vehicles (e.g., feller-bunchers) on dry soils is recommended.

I ntermediate-quality (Type II) flatwoods and subxeric sandhills are candidates for selective logging of the canopy, if timing is such that damage to groundcover is minimal. Examination of wetland inclusions should occur beforehand so that loggers avoid these areas, to minimize disturbances to groundcover and hydrology. I ntermediate-quality xeric sandhills should not be subjected to logging with heavy equipment because the groundcover may be slow to recover in these nutrient and water-stressed sites. In Type III and IV sites, use of heavy logging equipment to thin the midstory is acceptable using least disturbance methods. Erosion problems caused by logging should be mitigated.

Moderately low-quality flatwoods and sandhills sites are candidates for overstory cutting using group selection or shelterwood management, if (1) no adjacent wetlands will be impacted (see Alteration of Hydrology, p 47, for discussion of 
buffer zones), and (2) cutting will not lead to significant erosion. Seed tree regeneration systems (leaving a few reproductive trees on site) are not recommended for longleaf pine sites because the site can become overgrown with hardwoods and brush while waiting for a heavy seed crop, subsequently increasing costs of regeneration (Boyer 1993).

In sites that are cut, managers must ensure adequate spacing of trees, proper thinning, and use of frequent fire in the future, so that later stages of development do not shade out native groundcover species (Glitzenstein 1993). Fort Polk only allows selective removal of poor quality trees (Fort Polk anonymous reviewer, 13 August 1996). Reisinger et al. (1988) provided several recommendations for minimizing soil disturbance during logging operations. Only those recommendations that appear to be compatible with rare species management are provided:

- Soil survey maps, which include descriptions of drainage, and other soil properties, can be used to design and locate roads, landings, and skid trails in the most resilient sites. Maps can also provide TES locations or significant natural features to avoid. Use of designated skid trails will reduce disturbance, by restricting machine travel to fewer trails, rather than traveling from stump to stump.

- $\quad$ Schedule the season of logging to avoid operating when the water table is high, and select the proper type of logging equipment to minimize soil disturbance.

- $\quad$ Site preparation through prescribed burning before logging can improve operator visibility and help the operator avoid obvious wet spots.

Personnel from Fort Polk (S. Reilly and an anonymous reviewer) provided these additional recommendations to minimize soil disturbance caused by selective logging operations:

- Equipment operators should minimize the number of turns that are made, in addition to the number of skid roads that are used.

- Loggers should carry cut trees to a main skid trail, using lightweight, maneuverable equipment such as a rubber-tired feller-buncher, rather than skidding them out. 
- $\quad$ Loggers should skid the whole tree, rather than removing the top of the tree and only skidding the trunk. The tree top will cushion the trunk, so that less damage to soil will occur.

- $\quad$ Placement of delimbing gates should be planned carefully to avoid impact on sensitive areas (e.g., wetland inclusions such as hillside seeps) by falling debris. (Although Fort Polk requires forestry operations without use of delimbing gates, so they may not be necessary at all.)

- $\quad$ Loggers should not cut trees in a straight line for a selective cut. Cutting in a straight line will encourage future use of the logged area as a road, which will discourage natural regeneration. On F ort Polk, straight line harvesting is prohibited.

- If logging operations must occur in areas harboring sensitive plant species, population boundaries should be marked with flags, and operators should be required to avoid the flags. This practice has been successful at F ort Bragg.

\section{Mechanical Site Preparation}

Impacts. Site preparation is an important component when planting longleaf pine stands for timber purposes (Fort Polk, anonymous reviewer, 13 August 1996). Mechanical site preparation methods vary, as do effects on groundcover vegetation. Someauthors haveused results of studies on impacts showing increases in diversity (e.g., Conde, Swindel, and Smith 1983), to argue that mechanical site preparation does not harm the groundcover. However, botanists have pointed out that species' composition changes following mechanical site preparation, and that nativespecies such as wiregrass are replaced by weeds following groundcover disturbance (reviewed in Abrahamson and Hartnett 1990; Glitzenstein et al. 1993). In addition, harvesting followed by intensive site preparation practices may result in serious depletion of soil organic matter and associated nutrient reserves (F isher 1981).

Stump removal, windrowing, and disking expose mineral soil and are considered to be highly destructive to many groundcover species (Glitzenstein et al. 1993; Swindel, Conde, and Smith 1982). In a study in northern Florida, these practices caused many herbaceous species populations to decrease drastically, while others increased (Swindel, Conde, and Smith 1982). In sandhill sites in Florida, Outcalt (1993, in Glitzenstein et al. 1993) noted a large decline in wiregrass cover from rootraking and other systems where windrows and piles are made. A study by Schultz (1976) showed that disking caused significant decreases in wiregrass and Curtis' dropseed, and an increase in panic-grasses. For bluestems, there was relatively little difference between controls and intensively site-prepared plots, but 
different species of bluestems were not examined (Schultz 1976; reviewed in Glitzenstein et al. 1993). Stumps themselves support a variety of animals that utilizethe cavities, holes, and decaying root channels associated with them, so their removal not only disturbs soil, but also destroys habitat for animals. Circumstantial evidence suggests that small mammals, snakes (including the eastern indigo snake and diamondback rattlesnake) and other herpetofauna (including gopher frogs) usestumps as refuges (reviewed in TNC 1995 and reviewed in McMinn and Crossley 1993). Bedding is disruptive to groundcover species because it introduces environmental heterogeneity (by creating beds and furrows) in an otherwise flat or sloping area. Swindel, Conde, and Smith (1982) noted that bedding significantly affected the coverage of different grasses, but not of shrubs, forbs, or sedges.

Effects of roller-drum chopping on groundcover vegetation are less than those of mechanical site preparation practices described above. However, a single pass with a double-drum chopper can cause 50 percent mortality of wiregrass (discussed in Glitzenstein et al. 1993). Swindel, Conde, and Smith (1982) showed that, after dearcutting and chopping, wiregrass cover decreased significantly in cover and frequency, and thegroundcover becamedominated by panic-grasses and bluestems. However, in the sandhills, use of a smaller single-drum chopper (weighing 1.5 tons) can keep wiregrass mortality as low as 0 to 5 percent, because the oak stems provide a cushion for the roller which limits penetration into the soil. Roller chopping may be less destructive on dry than wet sites (discussed in Glitzenstein et al. 1993). U se of a bush-hog hydroaxe for shrub control does not usually affect groundcover (S. Bebb, pers. comm., 1996).

Based on professional experience and judgement, Robinson (1978) discussed the effects of mechanical site preparation practices on rare plant species. Hairy wild indigo, Florida leaf-flower (Phyllanthus leibmannianus spp. platyl epis), Bartram's ixia (Calydoria coelestina), and Georgia ironweed (Vernonia pulchella) have been observed to seed into sites prepared for pines. It was suggested that bedding would be acceptable for some species, as long as the beds were sufficiently wide to admit light into undisturbed strips. Disking was demonstrated to increase Rugel's pawpaw (Deeringothamnus rugelii), which produced new shoots from the cut roots, but windrowing eliminated the species (Robinson 1978).

Management recommendations. N o ecological benefits are gained using intensive site preparation activities that cause severe soil disturbance in Type I or II quality sites. Therefore, mechanical site preparation activities in these areas should be minimal and restricted to nonmechanical approaches, if possible. Intensive site preparation activities are known to lead to replacement of wiregrass groundcover 
by weedy species, and to exacerbate erosion problems. Instead, regular, frequent prescribed burning should beused to control hardwoods and regeneratenativepines whenever feasible. In areas that have been fire-suppressed, additional methods are needed, such as midstory thinning (Glitzenstein et al. 1993). For more discussion of using prescribed fire in fire-suppressed areas, see Fire and Fire Suppression, p 40.

In Type II and IV sites, mechanical site preparation activities using the least destructive methods may not harm TES species, so long as wetlands and an adjacent buffer area are not subjected to these activities. E rosion problems caused by these methods should be mitigated. Generally, if activities are timed to occur when soils are dry, damage will be less extensive.

\section{Livestock Grazing}

Impacts. Livestock grazing is generally not a common land use of pine flatwoods and sandhills on military installations. When intensive livestock grazing does occur, it can result in alteration of soil properties and vegetation structure. In areas that have been grazed for long periods of time, soil becomes compacted, reducing water infiltration and percolation (Myers and Ewel 1990). Increased grass production, decreased herb production, and altered composition were documented in dry flatwood sites under grazing pressure (Duvall and Linnartz 1967). However, Lewis Tanner, and Terry (1988) found that grazing had little effect on occurrence of herbaceous species in pine-wiregrass communities. Intermediate grazing may prevent highly competitive species from excluding others, thus enhancing species richness (reviewed in Walker and Peet 1983).

Grazing has varied effects on rare plants (Robinson 1978). Livestock trampling has negative effects on Vahl's fimbry (Fimbristylis perpusilla), E dison's St. J ohn's-wort (Hypericumedisonianum), Godfrey's butterwort (Pinquicula ionantha), and Florida mountain mint (Pycnanthemum floridanum). Other species, such as fall-flowering pleatleaf (Nemastylis floridana) and Florida skullcap (Scutellaria floridana) are crowded out by the closed mass of grasses in pastures. Florida hartwrightia (Hartwrightia floridana) cannot be found where cattle are grazing, though it might be abundant on either side of the pasture fence. Unpalatable species not affected by grazing are purple balduina (Balduina atropurpurea), slim petal pawpaw (Deringothamnus pulchellus), and Rugel's pawpaw. Georgia ironweed can survive moderategrazing, and rain lily (Zephyranthes si mpsonii) and easter lily (Z. treatiae) benefit from controlled grazing (Robinson 1978). 
Management recommendations. Livestock grazing contributes to soil disturbances, but is probably compatible with most pine woodland TES. While intensive grazing systems should be discouraged, especially in Type I sites, moderate grazing has not been shown to significantly damage natural woodland communities in the southeast (G. Tanner, professional discussion). Grazing should be monitored so any impacts can be identified and mitigated early.

\section{Military Training}

Impacts of mechanized military training. Most research on mechanized training impacts has been conducted in the western United States (reviewed in Trame 1997; Guertin 1995). Available research has shown that most damage occurs from offroad movement (Michigan DMA 1994) and under wet soil conditions (Thurow et al. 1993). Direct impacts to soil characteristics, including altered oxygen, water, and nutrient content, and changes to $\mathrm{pH}$ and infiltration rate, lead to reductions in germination, growth, and reproduction in native plants (Cole and Landres 1995) and changes in species composition and community structure (Beije 1987; Coleand Landres 1995). These findings are consistent with those from one study in the Southeast. On Fort Benning, GA, sandy ridges in the longleaf pine-turkey oak community subjected to tracked vehicle use now resemble old field successional areas; frequently used areas are completely barren (Goran, Radke, and Severinghaus 1983). On F ort Polk the following observations were made: (1) areas of bare ground, without seedl ings, were criss-crossed by vehicle tracks and scarred by vehicle-dug pits (Figure 12), (2) a reduction in vegetation at the ground, shrub, and tree levels, (3) trees bent, twisted, and scarred by direct vehicle impact, (4) trees fallen or standing dead or partially dead, apparently because of root damage caused by repeated vehicle passing near them. Researchers also measured fewer trees in mechanized training areas compared to control areas (100.5 trees/ha vs 193 trees/ha [40.7 trees/acrevs 78.1 trees/acre]), although treegrowth in training areas was higher ( $7.4 \mathrm{~mm} / \mathrm{yr}$ vs. $6.0 \mathrm{~mm} / \mathrm{yr}$ [0.29 in./yr vs $0.24 \mathrm{in} . / \mathrm{yr}$ ]) (Goran, Radke, and Severinghaus 1983).

In the absence of extensive studies on military activities, inferences can be made with known impacts of mechanical logging and site preparation activities. Impacts discussed elsewhere (see Mechanized Harvest Operations, p 55, and Mechanical Site Preparation, p 59) are probably similar to damage from mechanized military training. In particular, soil disruption and direct destruction of shallow-rooted groundcover species leads to domination by winter annuals and agricultural grasses (DA 1994), and a general decrease in diversity of theherb layer (Hart and Lester 1993). However, land-use patterns differ between forestry activities and military training. When skidding trees, forestry equipment operators 
create roads on areas that appear able to sustain vehicle traffic (Aust et al. 1993), and they traverse roads more or less consistently during a relatively brief harvesting timeframe. In addition, the forestry industry has improved machinery design to minimize soil damage (e.g., as discussed in Greene and Stuart 1985). Although these factors differ with the quality of any given forestry operation, the strategies that dictate military training movements are much different, and are probably more likely to affect larger areas of land, and at different intensities that are difficult to predict. However, some differences are dramatic. In maneuver staging areas (Figure 13) and land occupation sites (Figure 14), large patches of bare ground can develop and persist. High soil compaction can prevent regrowth of native groundcover, and these bare patches can effectively hinder the spread of fire.

Impacts of nonmechanized military training and recreation activities. The damage to ground cover and other plant species by military foot traffic and occupational exercises may be comparable to that caused by recreational activities such as hiking and camping. Most available data come from recreational studies outside the southeastern region. In these studies, trampling injury to plants by recreationists has effects similar to nutritional or disease stressors (i.e., abnormal cellular activity, and impaired processes such as root formation, photosynthesis, respiration, and energy metabolism) (reviewed in Kuss and Graefe 1985). Reduced growth, vigor, and reproduction are common impacts (Kuss and Graefe 1985, Cole 1987).

Sustained high levels of trampling can ultimately eliminate vegetation. Trumbull et al. (1994) documented a 57 percent decrease in woody stem density, a 72 percent decrease in understory cover, and an increase in bare ground (17 percent cover vs 2 percent) in bivouac sites at Fort Leonard Wood, MO. Canopy cover was reduced for height classes of 0.6 to $1.0 \mathrm{~m}$ (2.0 to $3.3 \mathrm{ft}$; Trumbull et al. 1994). J ames et al. (1979) documented the loss of all vegetation except mature trees in northwestern Ontario. Garton, Hall, and Foin (1977) found a decrease in plant abundance for plants less than 7.6-m (25-ft) tall, loss of foliage under 6.2-m (20-ft) high, and a 49 percent increase in bare soil as a result of recreational camping in California. Blakesley and Reese (1988) found lower shrub, sapling, and tree densities in campground sites vs noncampground sites in northern Utah. Based on these findings, it is likely that intensive nonmechanized military training (and recreational activities) in the Southeast would also lead to reductions in ground cover and, possibly, reduced pine regeneration. In general, reductions in plant heights, species richness. and cover are greatest in the core area of a campsite, and thus are localized impacts (Cole 1987). 
Trampling from recreation or military training can alter soil characteristics (see Soil Compaction, p 74, and Erosion/Sedimentation, p 69), which lead to population declines of native plants, simplification of vegetation, and loss of habitat diversity for the animals that rely on those plants (reviewed in Boyle and Sampson 1985). Harsh soil conditions favor species tolerant of moisture and oxygen stress. Early successional species, very sturdy species, and/or disturbance-adapted species arefavored, leading tochanges in community composition and structure(McDonnell 1981; Cole 1987; Tazik et al. 1992) such that native species richness and species diversity decline (Coleand Landres 1995). In general, grasses and sedges are more resistant to damage, while low shrubs, tree seedlings, and lichens are very susceptible (Cole 1987).

Trampling also can affect the plant community near frequently used footpaths. Within 1 to $2 \mathrm{~m}$ ( 3 to $7 \mathrm{ft}$ ) of the edge of the trail, the plant community is altered. Some species, especially those adapted to the forest floor, are eliminated, while disturbance-tolerant and trampling-tolerant species increase. Some species invade the areas near, but not immediately adjacent to, trails. Beyond this 1- to 2-m (3to 7-ft) trail border, minimal effects on native vegetation were observed (Dale and Weaver 1974).

Most data have been collected in recreational areas that sustain moderate or heavy use. However, Cole(1995) monitored changes to vegetation* after only 1 or 4 nights of camping. Vegetation typeand number of nights of camping each affected vegetation cover and vegetation height. After 1 year of recovery, differences in damage were reduced; vegetation that was most seriously damaged al so demonstrated a stronger ability to recover. Increases in trampling intensity lead to greater increases in vegetation damage compared to more nights of camping (Cole 1995). Unfortunately, these experiments were not performed in the southeastern region, so it is unclear how applicable the results may be for groundcover of pine sandhills. Since pineland groundcover species are adapted to the loss of above-ground parts, it is likely that they can sustain moderate trampling levels ( $A$. Weakley, pers. comm. 1995; R. Stewart, pers. comm., 1995). Most concern has been focused on wiregrass, since it has limited regeneration potential once individual clumps have been killed (Noss 1989; Duever 1989; Clewell 1989).

Management recommendations. I ntensivefoot traffic, occupational exercises, and mechanized training should be minimized in high-quality flatwoods and sandhills. Use of drier flatwoods for these activities is preferable to use of wetter areas of the

\footnotetext{
* Study sites were: (1) Cascade Mountains of Washington, (2) Rocky Mountains of Colorado, (3) the northern hardwood Presidential Range in New Hampshire, and (4) Smoky Mountains of North Carolina (Cole 1995).
} 
same quality, because drier flatwoods appear more resilient than do wetter areas. Similarly, damage resulting from foot traffic or low-intensity mechanized training may be reduced if activities are scheduled to occur during seasons when soils are dry. However, frequent, extensive mechanized maneuvers likely will result in such extensive and permanent fragmentation of the ground cover/fuel load (and consequent alteration in community composition) that seasonal differences in soil moisture may play a minor role, when compared to traffic intensity (A. Weakley, pers. comm., 1995; M. MacRoberts, pers. comm., 1995).

I ntensive military activities such as occupation and assembly should occur on fewer, permanently improved ("hardened") sites, or on those that are not improved but repeatedly used, rather than on many sites that are used in a rest-recovery rotation. This recommendation is made because it is likely that the resting periods would betoo short to allow regeneration and recovery of the natural community (A. Weakley, pers. comm., 1995). When additional occupation, assembly, or maneuver training sites must be used, care should be taken to minimize fragmentation of the larger community so that landscape-level hydrologic processes and fire regimes are less impacted (Hart and Lester 1993).

\section{Restoration Activities}

\section{Longleaf pine regeneration.}

I mpacts. Using growing-season prescribed firefor natural regeneration of I ongl eaf pine will benefit the native ground cover. However, seedlings can be planted by hand or with machinery when natural regeneration is not possible.

Hand planting of seedlings causes minimal soil disturbance. Seedlings planted mechanically (e.g., using a V-blade planter) causes significant soil disturbance. However, compared to other kinds of mechanical disturbance, the disturbance caused by the $\mathrm{V}$-blade planter is minimal. Planting longleaf pine is better for the ground cover when compared to planting other pines, becauselongl eaf pinesaplings have a more open canopy. Thus, more light is able to reach the ground cover. Longleaf pine also can be burned at a younger age, which helps to control hardwoods and thin pine trees (Glitzenstein et al. 1993).

Management recommendations. Prescribed growing season fires are recommended to maintain the native groundcover and to prepare the seedbed for natural longleaf pine regeneration (see Fire and Fire Suppression, p 40). Usually, a burn within 1 year before seedfall will provide an adequate seedbed (Boyer 1993). 
If natural regeneration of pine is not possible, hand planting containerized longleaf pine is preferable to machine planting (Dept. of the Air Force 1993), and should be the method used in high- and intermediate-quality sites. Machine planting is acceptable in moderately low and lowest quality sites. Future management must ensure that a dense stand which will shade understory species does not develop in stands that support native ground cover or TES.

In sites formerly occupied by longleaf pine that have been converted to other, less fire tolerant pine species through long-term fire suppression, managers should consider replanting longleaf pine (F igure 11). Replanting will increase the size of woodland remnants over time, connect fragmented areas, increase flexibility regarding TES management, and help to restore fire in areas that have been fire suppressed.

\section{Midstory reduction.}

Impacts. Herbicides are often applied to eliminate competing hardwoods and to remove unwanted exotics. When herbicides are applied to target vegetation with broadcast application methods, other plant species are likely to be impacted negatively. A study conducted by Swindel et al. (1989) in pine flatwoods showed that chemical weed control markedly reduced plant species diversity. When herbicides are applied directly to target vegetation, effects on nontarget plant species should beminimal. Nontarget species may even show an increase in growth after application of herbicide to nearby target vegetation, due to decreased competition.

Hexazinone (VELPAR-L ${ }^{T M}$ ) is commonly applied in sandhill sites to control oaks and other woody species. Hexazinone is nonselective (e.g., it is toxic to almost all vegetation), so care must be taken to avoid damage to nontarget, desirable vegetation (Langeland 1990). Broadcast application of hexazinone in sandhills in Ocala National Forest, FL, killed wiregrass, but the same concentration applied around the bases of turkey oaks in a north Florida longleaf pine forest affected less than 5 percent of the wiregrass. In addition, the remaining wiregrass in this site showed vigorous growth and some even flowered, even though the site had not burned for 20 years. Although the shallow-rooted wiregrass was killed from only a direct application of hexazinone, deep-rooted turkey oaks died $3 \mathrm{~m}$ (10 ft) away, suggesting that deep-rooted herbaceous perennials may respond differently than wiregrass to herbicide treatments (Duever 1989).

\footnotetext{
* Researchers in this study applied herbicide using broadcast application of sulfometuron methyl $(0.56 \mathrm{~kg} / \mathrm{ha}$ active ingredient (a.i.) in $80 \mathrm{~L} / \mathrm{ha}$ of water carrier) in April, with maintenance application $0.28 \mathrm{~kg} / \mathrm{ha}$ a.i. in June 1983.
} 
Species that are resistant when hexazinone is applied directly to oak species are Florida arrowroot (Zamia pumila), Carolina jessamine (Gelsemium spp.), greenbriar, and all of the blueberries. Native legumes that increase in growth following application are partridge-peas (Cassia spp.), lespedezas (Lespedeza spp.), milk peas (Galactia spp.), butterfly peas (Centrosema spp.), and wild indigos (Baptisia spp.). Spurges, noseburns (Tragia spp.), Queen's delight (Stillingias spp.), and a few composites also respond well, but most rosette forming composites are inhibited by hexazinone application (Glitzenstein et al. 1993).

On wet sites, the nonselective herbicide imazapyr (Arsenal ${ }^{\mathrm{TM}}$ ) is commonly used to control woody vegetation. The chemical is still relatively new, and not much information is available on how it affects other species in the community (Glitzenstein et al. 1993). Triclopyr and 2,4-D are examples of selective herbicides that are most effective at killing broad-leaf plants (dicotyledons) while grasses and related plants (monocotyledons) are relatively tolerant to it (L angeland 1990).

Management recommendations. Manual methods, such as hand falling or girdling using chainsaws also can be used to reduce hardwoods. Hand falling or girdling results in the least disturbance to the ground layer, but this method may not be feasible across large areas (Provencher et al. 1995).

Herbicides should not be broadcast in Type I or II sites without careful consideration. Direct application of hexazinone (e.g., Velpar) on oaks, for restoration purposes, appears to work well in sandhills restoration efforts. Direct application of approved herbicides to target species should have minimal effects on understory vegetation or TES. However, hexazinone should be used with caution because of its high soil solubility, potential mobility in deep sands, and high toxicity to aquatic organisms (reviewed in Provencher et al. 1995). Direct application of hexazinone is appropriate for restoration purposes in Type II or III quality sites, so long as appropriate buffer zones around wetlands and significant watersheds are designated.

Littleinformation is available for imazapyr, suggesting that more testing is needed for this chemical. Effects of imazapyr on nontarget species should be studied in TypeII and IV quality sites only (provided it is not used in wetlands or the adjacent buffer zone). Effects of all herbicides on nontarget vegetation should be monitored. For additional general information regarding management using herbicides, refer to Exotic and Pest Species, p 79. 


\section{Restoration of Native Ground Cover}

Restoration of nativeground cover is a time-consuming and expensive undertaking. Therefore, if large-scale disturbance to ground cover is necessary, it is prudent to plan contributing activities for areas that no longer support TES or the native, pyrogenic ground cover needed to support TES in the future. Following disturbances, areas that did not originally support native ground cover should more quickly recover to predisturbance vegetation becausethat vegetation generally consists of weedy species that are good colonizers of disturbed areas and function well to stabilizethe soil. These species should easily reestablish on thesite. Conversely, areas that support native ground cover (e.g., wiregrass) have been shown not to return to native vegetation following removal of ground cover.

This section applies to areas that support longleaf pine, but no longer have native ground cover, or areas that do not have enough native ground cover to spread fire. Managers may wish toconduct groundcover restoration tolessen fragmentation and restore natural fire regimes within the community, to expand or improve the existing habitat to support TES, or to reduce erosion and sedimentation.

Restoration of wiregrass. Wiregrass can be restored by seed by transplanting container-grown seedlings, or by translocating individuals from other sites. As always, when using transplants or direct seeding, managers need to be aware of genetic implications and the origin of the transplanting stock before making decisions on transplanting (Duever 1989).

Restoration of wiregrass (A. beyrichiana) by seed was shown to be successful in a recent Florida study (Seamon et al. 1989). The authors recommended conducting a germination bioassay first to identify a viable seed source,which they identified by collecting seeds 5 to 8 months following summer burns, placing seeds on moist filter paper in petri dishes, and sowing them into flats containing commercial potting soil and soil from a native site. Germination occurred within a few days ( 25 percent germinated in the petri dishes, and 20 percent germinated in the flats). Timing of seed collection is apparently important, as seeds collected earlier or later had low germination rates. The lower rate was probably because, when collected earlier, the seeds were not mature or, when collected later, they had already dispersed. In addition, commercial cultivation of A. stricta may have been successful in Southern Pines, NC (M. Schafale, pers. comm.).

After identifying a viable seed source, the following recommendations were made to restore wiregrass by direct seeding (Seamon et al. 1989): 
- $\quad$ Prepare plots by burning a few months before seeding will occur.

- Collect viable seed using a weedeater adapted for seed collection, a mower, or another type of harvester.

- Broadcast seeds on plots during the wet season. The soil should be lightly tilled or mulched to provide cover.

To establish wiregrass using container-grown seedlings, the authors recommended the following:

- Use a weedeater mechanism to collect sufficient viable seed by hand.

- $\quad$ Sow seeds in small plastic bedding plant containers, using a 3:1 native/potting soil medium.

- Keep seedlings moist and grow them in partial shade.

- Transplant wiregrass plugs into the field after they have grown for 1 to 2 years.

- Transplant during the beginning of the summer wet season to best assure successful establishment.

Translocation of wiregrass into new sites has also been used with success. Transplanting entire clumps may be a way to rescue plants from sites scheduled to be cleared. On sites not in immediate danger of destruction, entire plants should not be removed, but individual culms could be removed instead (Duever 1989). Heuberger and H uffman (1992) wereabletotransplant wiregrass and other grasses (splitbeard bluestem, Indian grass (Sorghastrum secundum), and little bluestem) into Myakka River State Park in Florida. Six-month survival rates were high (greater than 94 percent), and plants flowered during the fall census. Plants were translocated in May and J une of the wet season to ensure that they would receive sufficient moisture. Plants were removed from the soil with a shovel (avoiding damage to the root ball), transported, and planted in the new site to the same original depth. In another experiment, wiregrass clumps were broken into small pieces and potted, then grown in a nursery for 4 to 7 months, and planted out in late summer in central Florida. These transplants grew and flowered. Matching the transplant's original soil and community type with that of the new habitat may ensure greater transplant success (reviewed in Duever 1989). 
Restoration of other native grasses. Use of prescribed growing-season fireappears to be the best method to restore ground cover in communities outside the range of wiregrass. Managers should also learn what species other than wiregrass should be included in the restoration. Many available species lists are based on surveys from degraded sites that have been invaded by weedy flora and have lost sensitive species (reviewed in Duever 1989). Managers have had success transplanting nativegrasses intosites (e.g., splitbeard bluestem, I ndian grass, creeping bluestem; Heuberger and Huffman 1992; see Restoration of wiregrass, $p$ 68).

\section{Erosion and Sedimentation}

Impacts. Human activities that compress or expose soil, alter its porosity and hydraulic conductivity, or reduce plant cover (see Groundcover Disturbances, p 51, and Soil Compaction, p 74), will increase erosive forces and accelerate erosion. For example, soil compaction, which can result from forestry practices or military activities conducted with heavy machinery, leads to decreased water infiltration and increases in water yield, streamflow rates, and storm flow volume (stream flow attributable to a storm). The resultant increase in water flow (overland and streambed) has higher erosiveforcethan normal (Vachta and Riggins 1990).

Natural factors such as slope, precipitation, and soil texture influence erosion rates as well. For example, erosion and sedimentation do not appear to be a significant problem in pine flatwoods because of their flat topography (Swindel et al. 1983, A. Weakley, pers. comm., 1995). Sediment in streams and forest road ditches does not move appreciable distances and is thought to result from localized erosion. However, although harvesting results in increased water yield and flow rates (a result, in part, of decreased transpiration rates), theseincreases arerelatively short lived compared to the changes seen in more northern communities (Swindel et al. 1983).

In hilly east Texas uplands, forestry practices lead to significant increases in storm flows. Watersheds (up to 25 percent gradient) that were clearcut, sheared, windrowed, and burned had higher stormflows than thosethat were clearcut, roller chopped, and burned. Both treatments had higher storm flow values than undisturbed watersheds. These differences declined through time, but were still present after 4 years (Blackburn et al. 1987). Clearcut harvesting alone leads to higher storm flow, probably from reduced evapotranspiration and reduced soil infiltration rates (Blackburn et al. 1987). Additional, significant effects from site preparation (shearing + windrowing or roller chopping) were documented also. 
Since shearing and windrowing created more soil disturbances, they lead to larger stormflow increases than did roller chopping (Blackburn et al. 1987). Clearcutting and site preparation resulted in significant increases in erosion (Blackburn et al. 1987).

In a different study in Louisiana, the combination of a seedtree cut, chopping or harrowing, and then burning created more erosion than did thinning plus prescribed burns on a 3-yr rotation (Wood et al. 1987). However, losses from all experiments were well within the range of natural sediment loss measured from undisturbed watersheds in the southeast (trace amounts to $640 \mathrm{lb} / \mathrm{acre}(718 \mathrm{~kg} / \mathrm{ha}$; Yoho 1980). Vegetation cover is critical to erosion control; as time passes after site preparation and vegetation becomes re-established, increases in storm flow or runoff do not necessarily lead to high sediment losses (Blackburn et al. 1987).

The importance of vegetative cover was al so demonstrated after fire in sandy loam sites in Louisiana. For a brief period in which bare soil was exposed, burning increased sedimentation rates. In addition to the percentage of bare soil, grass cover, bulk density at 5-cm (2-in.) depth, and surface silt also influenced sedimentation rates. On the other hand, sedimentation did not increase at all after burning on silt-loam soils in the same study. Although the potential for soil loss exists after burning an erosive silt-loam site, the rapid recovery of plants on these soils and flat terrain prevent perpetual losses (Dobrowolski, Blackburn, and Grelen 1987).

Most erosion resulting from forestry is from poorly constructed and maintained roads, especially if traffic moves perpendicular to drainage ditches or natural contours of the land (Askew and Williams 1984; Y oho 1980). Sandy uplands soils are susceptible to gully erosion (Figure 15), which channels water movement and carries the sandy soils into lower-lying areas (J . Murian, pers. comm., 9 Nov 1995) (Figure 16). Long-term losses of water and nutrients through this process may threaten the integrity of some upland communities (Russo et al. 1993). On some military installations, erosion and siltation from mechanized training activities present the greatest impacts to natural communities and rare species. Erosion is most damaging when the sediment is deposited in wetland basins, streams, or lakes. However, even some uplands have been degraded by ongoing, large-scale siltation (Russo et al. 1993).

Management recommendations. Erosion control is an essential component of sound land management on DoD lands in the Southeast. The loss of vegetative cover in areas that receive intensive, repeated use for vehicle maneuvers or occupation is unavoidable. Subsequent soil loss from these areas will contribute to 
sedimentation within entire drainages. It is necessary to arrest the erosion process early in its development and restrict erosion to the smallest areas possible. Although erosion cannot be prevented entirely, it can be harnessed before it damages valuable wetlands, lowlands, stream courses, endanger ed species habitat, or other high-quality sites. Two management rules may improve planning and implementation of an erosion management strategy:

1. Manage for quality wetlands, stream courses, ponds, and lakes. If wetlands and waterways are high quality, the ecological status of uplands and terrestrial systems probably will beacceptable as well. This assumption is not meant to suggest that managers should not monitor terrestrial sites, but that wetlands and streams can serve as critical indicators for overall ecosystem status.

2. Correct erosion and sedimentation problems immediately. Repair damage before it becomes an obstacle to training or a threat to the integrity of TES habitat. This will be more cost-effective and sustainable in the long term. In the sandy soils of the Southeast, small gullies quickly degrade over short distances into deep ravines that can continueto cut back and erode, even after aggressivemitigation measures have been taken. Most of the following recommendations to reduce erosion were offered by J ordan, Wheaton, and Weiher (1995) and Dept. of the Air Force (1993):

- Avoid construction of plowed fire lines near stream corridors, and stabilize and revegetate emergency lines immediately after fire suppression.

- Avoid designation of logging roads and skid trails on slopes with erodible soils or within $31 \mathrm{~m}$ (102 ft) of streams. When logging is completed, block off access roads and revegetate them with native species.

- Evaluate all stream crossings for their contribution to erosion. Close unnecessary crossings or those which are damaging to sensitive species and habitats. A flat concrete pad that does not alter natural water flow and prevents soil disruption (known as an "Irish Bridge") is one inexpensive alternative to using culverts. This method has proven successful at Fort Pickett, VA (J . Proffitt, pers. comm., 1996).

- In areas used primarily for dismounted infantry training, flag wetland ecotones and ephemeral ponds to protect them from occasional but unnecessary off-road vehicle impacts.

- Evaluate thenecessity of the existing road network and any proposed road construction; stabilize, close, and revegetate any unnecessary secondary 
roads. Devel op new roads to be compatible with the natural contours, hydrologic flows, and erosive potential of the soils, along with slope and wetland locations. Raise road maintenance standards to reduce erosion from road shoulders.

- Avoid conducting any nonmission activities that might increase erosion of uplands and consequent sedimentation into lower-lying flatwoods, ecotones, or adjacent wetlands. These activities may include pinestraw raking, timber harvest, and clay and sand removal on adjacent uplands (Russo et al. 1993).

Some erosion is unavoidable because of the nature of the military training mission, especially on Army lands. However, much erosion occurs dueto nonmission-related off-road driving (J. Proffitt, pers. comm., 1996). Improved planning and communication by the training community can reduce the impacts from these maneuvers. Fencing may help protect areas experiencing chronic, nonmissionrelated off-road trafficmovement. Land-based training sometimes requires realistic practice in bridge construction and fording of waterways. This practice can be devastating to natural streams and rivers, especially when training schedules are heavy. Fort Pickett devised an alternative site for engineering training by constructing an artificial pond, which was blocked by large berms and serviced by hardened parking areas. Military units can access the water from several different angles and are not constrained by weather or moisture concerns, nor will they impact the natural system. No known off-site impacts are affecting the nearby landscape (J . Proffitt, pers. comm., 1996; A. Trame, pers. obs.).

DoD land managers are encouraged to work proactively with the Natural Resource Conservation Service (NRCS), state Departments of Transportation, and land management researchers to receive site-specific erosion management and mitigation assistance (J . Williamson, pers. comm., 1995). In areas where intensive maneuver training will continue, traditional intervention using mesh nets, straw, rocks, and fast-growing grasses may be most appropriate, since it is critical to stabilize the soil quickly (J. Williamson, pers. comm., 1995). However, the introduction of nonnative species (directly or indirectly through the spreading of straw) for soil stabilization is a serious and fast-growing threat to natural communities in the region. Cogon grass (I mperata brasiliensis and I. cylindrica) and Bahai grass (Paspalum notatum) are already identified as species that are invading and disrupting native plant communities in Florida (Florida Exotic Pest Plant Council [EPPC] 1995), Alabama, Mississippi, and Louisiana. J apanese honeysuckle (Lonicera japonica), kudzu, and Australian pine (Casuarina cunninghamiana) were introduced as erosion control species with devastating 
consequences for the southeastern region (Gordon and Thomas in prep). When alternativetechniques exist, erosion control efforts on DoD lands should avoid using invasive exotics, because they may establish in natural communities. In the long term, this invasion can lead to more ecological damage than the original erosion problem. All new species must be viewed with suspicion and subjected to rigorous ecol ogical study before their use can be considered appropriate. In particular, the use of love grass (Eragrostis spp.) for erosion control in the longleaf pine ecosystem concerns some biologists (M. Schafale, pers. comm., 1995). Over the course of 1 year, evidence of rapid expansion of this species was noted on Fort Bragg (J. Shipley, pers. comm., 1996). Similarly, there is concern over the use of Vetiver spp. for erosion control (Dr. Nancy Coile, pers. comm., 1996; GregJ ubinsky, pers. comm., 1996).

Some land managers view the use of exotics as a last resort effort to control erosion in sites that will receive continued heavy use (J . Proffitt, pers. comm., 1996). Therefore, it may be acceptable to use annual grasses that will not out-compete native species over the long term (J . Williamson, pers. comm., 1995) rather than to revegetate with natives that are either slow to establish or do not have large enough seed sources to be practical.

Some military installations have discovered that the use of fertilizer and exotics in the longleaf pine woodlands (e.g., Fort Polk) may not be a problem. Once fertilizer use is discontinued, native species often out-compete the exotics and regain their place in the community (S. Parris, pers. comm., 1995). This approach was supported by D. Lane (pers., comm. 1995) and J . J ohnson (pers. comm., 1995). However, other experts have expressed concern that these practices may lead to invasion by exotic plants, or that applied fertilizers will make their way into wetlands and streams, altering nutrient regimes and seriously degrading these sensitive communities. During revegetation of areas that have been impacted by grazing or timber harvests, plantings of exotic species and application of fertilization has caused more damage than the original soil disturbance and vegetation losses (USFS representative, pers. comm., 1995). Further applied research is required to assess the risks involved for different TES species, plant communities, and soil types.

It is hoped that native grasses (i.e., switchgrass and broomsedge) in conjunction with forbs such as goat's rue or Virginia tephrosia (Tephrosia virginiana) and partridge pea (Chamaecrista fasciculata) can be used soon for erosion control in the longleaf pine woodlands, although additional research would help determine the best uses and methods of use for these species (D. Lane, pers. comm., 1995). Table 6 is a complete list of potential erosion control species. To date, revegetation with 
natives has been hampered by the species' slow germination and establishment rates (D. Lane, pers. comm., 1995; J . J ohnson, pers. comm., 1995), limited seed sources (R. Stewart, pers. comm., 1995), and a scarceness of research on southern ecotypes for this purpose (R. Hansard, pers. comm., 1995). Research is being conducted to identify appropriate native species and propagation/application methods for erosion control on tank maneuver sites at Leesburg Training Site, SC (Research Proposal, "Development of Vegetative Management Strategy for Disturbed and Eroded Areas on Military Training Areas," submitted to the South Carolina Army National Guard, September 1994).

\section{Soil Compaction}

Impacts. Effects of timber harvesting on soil compaction in the South were reviewed by Reisinger et al. (1988); soil compaction in general was reviewed by Greacen and Sands (1980). All harvesting activities cause some compaction, but the degree of compaction varies with equipment, technique, intensity, soil properties (such as texture and moisture), and vegetation cover (Reisinger et al. 1988, Aust et al. 1995). Most compaction occurs during the first few passes of a vehicle, and subsequent trips have little effect (reviews in Reisinger et al. 1988; Lockaby and Vidrine 1984). Moehring and Rawls (1970) and Greacen and Sands (1980) emphasized that more severe damage can occur from traffic on saturated soils compared with dry soils. For example, a tractor pulling three logs across dry soil removed soil litter, broke shallow roots, and scarified the soil surface. On wet soils, the same treatment removed most of the litter, sealed and ponded the soil surface, broke large roots, and increased the shallow bulk density measurements by 13 percent. In areas with few trees, deep gouges were created to a depth of 15 to $46 \mathrm{~cm}$ ( 6 to $18 \mathrm{in}$.) and deep roots were broken. These disturbances to wet soils also seemed to increase pines' susceptibility to black turpentine beetle attack (Moehring and Rawls 1970). Qualitatively different impacts and deeper disturbance profiles were also found by Aust et al. (1995) when they compared traffic on dry soils vs wet soils. Susceptibility of soil to compaction is correlated with organic matter; soils with high organic matter content are more difficult to compact (reviewed in Greacen and Sands 1980). Similarly, soil type has a strong influence on susceptibility to compaction and subsequent recovery. On Mississippi steeplands, loamy surface soils over clay subsoils were most compacted by logging activities (Miller and Sirois 1986). In general, silt and clay soils compact more severely than sandy soils (Dickerson 1975).

Most field studies indicate that soil compaction lessens over time as a result of the combined effects of root activity, freeze/thaw cycles, and wet/dry cycles. Clay soils, 
which swell and shrink, may partially recover with wetting and drying cycles, but recovery of sandy soils, if any, is usually slower (Greacen and Sands 1980). Deeper layers of compacted soil take much longer to recover. Although the upper $8 \mathrm{~cm}$ ( 3 in.) of sandy loam and loamy sand soils recovered in 5 to 9 years, layers bel ow 8 $\mathrm{cm}$ (3 in.) took much longer and depths of 15 to $25 \mathrm{~cm}$ (5.9 to $9.8 \mathrm{in}$.) showed no signs of recovery (Thorud and F rissell 1976, in Reisinger et al. 1988). A study in an Atlantic Coastal Plain loblolly pine plantation showed that soils compacted on logging decks gradually recovered to prelogged densities over an 18-yr period (Hatchell, Ralston, and F oil 1970), while Dickerson (1975) estimated a period of 12 years for Mississippi soils to recover normal bulk density and macropore values. (After 5 years, bulk density readings on logging roads were still high enough to interferewith pinespecies' survival and growth [Dickerson 1975]). Tracks on sandy soils under pine forests in Australia, which had not been used for at least 50 years, were still compacted compared to surrounding soil (Greacen and Sands 1980).

Generally, more soil disturbance (including compaction) is associated with clearcutting than with selective cutting or thinning (Reisinger et al. 1988). Dickerson (1968) reported 21 percent of soil on a dearcut stand was disturbed compared to 14 percent on a selectively cut stand. Also, twice as much soil was severely disturbed (bared, rutted, compacted) on the clearcut operation (reviewed in Reisinger et al. 1988). In addition, intensive silviculture treatments (seedtree cuts with roller chopping) produced lower combined infiltration rates over a 3-yr period than did extensive silviculture treatments such as thinning (Wood et al. 1987). Reviews of harvesting equipment effects on soil disturbance suggested that ground-based harvesting systems using rubber-tired skidders and crawler tractors generally caused more soil disturbance and greater soil compaction than other harvesting systems (e.g., skyline yarders, torsion suspension vehides). Most deeply disturbed and compacted soils are found in the primary skid trails and landing areas (Reisinger et al. 1988), although research has documented various degrees of damage. Aust et al. (1995) found a decrease in macropore space of 60 percent on rutted trails and 80 percent on compacted trails, with a 10-fold decrease in hydraulic conductivity. Penetrometer readings were 12 percent lower on loading decks compared to untrafficked areas, but this compaction was only found in the upper $2 \mathrm{~cm}$ (0.8 in.) of soil (Lockaby and Vidrine 1984). Earlier work had demonstrated compaction to $30 \mathrm{~cm}$ ( $12 \mathrm{in}$.) depths, with the highest levels between 10 and $15 \mathrm{~cm}$ (3.9 and 5.9 in.) deep (Taylor and Burnett 1964). Aust et al. (1995) found that dragged logs caused greater compaction than skidder tire tracks; however even tire track compaction was severe enough to limit root growth.

Compacted sites drain more slowly, as shown by higher water tables and lower soil oxygen (Aust et al. 1995, 1993; see Alteration of Hydrology, p 47). Soil com- 
paction reduces infiltration rates, which can increase surface runoff (Greacen and Sands 1980). However, runoff is affected by other factors, such as removal of vegetation (Greacen and Sands 1980). Soil compaction can lead to increased soil erosion when it increases runoff, but because compaction also increases soil strength, compacted soils may have lower erodability.

The effects of soil compaction on plant survival and growth are complex. Compaction alters soil strength, drainage, and aeration. Soil strength is a measure of its resistance to physical forces, including compaction and penetration by plant roots (Greacen and Sands 1980). Dry soils increase in soil strength as they become more dense, which reduces further compaction until, eventually, no further compaction can occur (Greene and Stuart 1985). Wetness in soils decreases their strength. Tree growth in a dry year can be more limited as a result of compression and water stress, while wet soils may not register any increase in strength, so roots may continue to grow (Greacen and Sands 1980). This occurrence has been seen in natural hardpans, which roots can penetrate during wet seasons but cannot during dry periods (Taylor and Burnett 1964). On the other hand, wet compacted soils usually have less available oxygen, decreased macropore space, and decreased hydraulic conductivity (Aust et al. 1993, 1995). These changes may then become the most important factors limiting root penetration and plant stress, especially on sites that naturally have good drainage and aeration (Aust et al. 1995). Other research showed that low oxygen may not be as critical as physical impedance. Taylor and Burnett (1964) and Day, Bassuk, and van Es (1995) agree that soil strength is more important than decreased oxygen, while Gill and Miller (1956) caution that relatively moderate declines in oxygen become important only when combined with mechanical impedance.

Compaction usually reduces nutrient uptake, especially that of phosphorous. It also can reduce mineralization and nitrification of soil nitrogen (reviewed in Greacen and Sands 1980). One rough estimate calculated that bulk densities of $1.21 \mathrm{~g} / \mathrm{cm}^{3}$ and higher restrict root growth, although this threshold varies with soil textureand plant species (Day, Bassuk, and van Es 1995). For example, Lull (1959; as cited in Kuss and Graefe 1985) stated that root growth becomes restricted when bulk densities reach $1.4 \mathrm{~g} / \mathrm{cm}^{3}$ (0.80 oz/cu in.) in fine textured soils and $1.6 \mathrm{~g} / \mathrm{cm}^{3}(0.92$ oz/cu in.) in coarse textured soils.

Little information is available on the effects of compaction on TES plant populations. Because many TES in flatwoods are wetland plants, effects of compaction on hydrology are likely to affect TES populations significantly. Flatwoods sites often have a subsurface clay hardpan, which is inherently low in hydraulic conductivity, so lateral subsurface flow is important. In a study within 
flatwoods of the Francis Marion National Forest, SC, compaction from skid trails reduced lateral groundwater flow and dried one side of the study site (Aust et al. 1995). This condition would be expected to affect TES, which often occur in wet situations in flatwoods and sandhills. In a restoration study conducted at Eglin AF B, sandhills sites that showed signs of compaction and extensive soil disturbance were the most species depleted, and also supported greater densities of weedy species (Provencher et al. 1995). These compacted sites had been sel ectively logged during thelate 1960 's with D-4 bull dozers and tractors (L. Provencher, pers. comm., 1995).

Cattle grazing, recreational land uses, and nonmechanized military training contribute to soil compaction to varying degrees. A summary of grazing literature concluded that light-to-moderate grazing by cattle has no significant impact on soil infiltration rates, but there appears to be a threshold with heavy grazing at which compaction occurs (Temple and Mendel 1995). In Louisiana, grazed areas had lower combined infiltration rates than ungrazed areas (Wood et al. 1987). Athough camping compacts soils and tramples vegetation (Col e1987; K uss and Graefe 1985), recreational camping sites are few enough on DoD lands in the Southeast to be of negligible consequence. On the other hand, military occupation, which involves a combination of vehicle and nonmechanized trampling, is a serious source of soil compaction and related impacts, if such activities occur in TES habitat. Casual inspection of bivouac sites often reveals a barren understory, with few herbs or shrubs, stressed overstory trees, and highly compacted soils (A. Trame, pers. obs.). Trumbull et al. (1994) found a significant increase in bulk densities in a long-term bivouac site in the Missouri Ozarks compared to nearby control sites, but infiltration rates were not different, and the radial growth rates of overstory trees were comparable. Any negative effects from the compacted soils could have been balanced by release of competition because stem densities were much lower in the bivouac site (Trumbull et al. 1994). The most serious environmental consequence from recurrent bivouacking and recreational trampling of vegetation and soil compaction is the reduction of woody reproduction because of direct destruction and limited germination and survival of seedlings (Kuss and Graefe 1985). Over time, the overstory matures and dies, and the area becomes denuded (A. Trame, pers. obs.). In the absence of land rehabilitation efforts, continued bivouac devel opment and abandonment can result in an ever-increasing portion of the landscape becoming less valuable for TES conservation, forestry, or military training.

Although no research documents compaction of soils from mechanized military training in the Southeast, impacts documented from forestry operations are probably representative of the potential impacts from tank or truck off-road maneuvers. However, there are important differences (see Mechanized Military 
Training, $\mathrm{p}$ 78). Although there may be site-specific variation, it appears that compaction from mechanical vehicles, whether during logging operations or military training, should be monitored and managed. Coastal plains soils may be wet, have little organic matter, and are sandy, with varying degrees of clay content. When compared to dryer sandhills, flatwoods soils may have a greater chance of recovery from compaction because they experience wet/dry cycles and possible swelling and shrinking.

Management recommendations. Availableinformation suggests that heavy equipment should be confined to improved roads in Type I or II areas, because soils in these areas are slow to recover from disturbance. Activities to repair the effects of compaction would also destroy the native ground cover, so they should not be promoted in TES habitat (see Groundcover Disturbance, $\mathrm{p}$ 51). It may be best to continue heavy equipment operations in degraded areas that have al ready been disturbed and compacted, because this practice will minimize the total area that eventual ly becomes damaged. In these damaged areas, restoration activities such as ripping and disking would be appropriate, as long as erosion control measures were taken to prevent off-site impacts.

When it is necessary to use heavy vehicles on sites (regardless of quality), wet sites should be avoided (Greacen and Sands 1980) because these soils are more prone to compaction. Wet sites should be viewed as having a narrower window of time in which activities, such as training or timber harvests, can occur (Aust et al. 1995).

Managers may want to consider using machines that cause less compaction, or use machines or management practices that affect a smaller proportion of thesite. For example, selective cutting or thinning is preferred over intensive silvicultural practices (Wood et al. 1987).

Management of bivouac sites is needed to reduce damage and off-site impacts. The recreational camping literature has demonstrated that campsites in use for 5 years have 86 percent the damage of sites used for longer than 13 years. In comparison, recovery takes decades (Cole 1987). When degradation occurs at a much faster rate than recovery, rest-rotation systems are ill-advised. Thus Cole $(1987,1995)$ and others have consistently recommended "confining camping to a small number of campsites instead of dispersing use across a large number of campsites." However, military bivouacking is substantially different than wilderness camping. Disturbances caused by bivouacs are largely due to vehicle movement within woodland areas, so the rate of damage and the length of time that damage continues to accumulate to soils are likely to be greater. Although a rest-rotation may not truly allow restoration of military bivouacs, short periods of time for soil 
stabilization to prevent erosion off-site might be worth a short-term shifting of land use to other sites. Otherwise, limiting the number of areas impacted by bivouac activity is a worthwhile strategy. Fort Pickett has reduced impacts to soils and partially protected islands of natural vegetation, including young trees and ground cover, by adding rock to the most frequently used pathways within bivouac sites ( $A$. Trame, pers. obs.). The hardened paths convince vehicle operators to voluntarily avoid bare soils, especially during wet periods (J . Proffitt, pers. comm., 1996).

\section{Exotic and Pest Species}

\section{General}

Impacts. Activities that disturb soil or alter hydrology-especially bulldozing of roads, fire lanes, and military vehicle maneuvers-increase susceptibility of pine communities to invasion by species not natural to the community. Old-field weed species may invade following disturbances, which may reduce fire frequency and facilitate hardwood invasion (Abrahamson and Hartnett 1990). Table 7 lists activities that may increase susceptibility of pine flatwoods and sandhills to invasion by exotic or pest species. Information on specific exotics and pests of flatwoods and sandhills is provided in the remainder of this section.

Management recommendations. In general, the presence of exotics and pests in natural areas should be viewed as indicators of unnatural disturbances affecting the community. Thus, control should be primarily through preventing the conditions that allow for their establishment. In general, activities listed in Table 7 should be avoided in TES habitat, as these activities increase community susceptibility to invasion by exotics or pest outbreaks. However, for communities currently having problems with exotics and pests, management recommendations for their control are outlined in the following subsections.

\section{Feral Hogs}

Impacts. Feral hogs appear to pose the most serious exotic species threat to TES populations in Iongleaf pine communities. Experimental studies have shown that moderate to heavy populations of feral hogs can cause the failure of Iongleaf pine regeneration, because the hogs feed on the seedlings (Lipscomb 1989). At Eglin AF $B$, hog activity has been reported tokill plants directly, increasesoil erosion, and facilitate weedy species invasion. Hog activity can degrade habitats so severely that they are nolonger able to support native ground cover and TES (F NAI 1994b). Hogs are especially detrimental to wetlands at Eglin AFB. 
Management recommendations. Hog populations should be aggressively controlled; eradicated, if possible. Hogs should be trapped in areas where hunting is not allowed. Daily bag limits on hunting hogs should be liberalized or discontinued, and hog hunting should be allowed whenever other game seasons occur. Hog populations should be monitored to assess the effectiveness of control efforts (F NAI 1994b).

\section{Fire Ants}

Impacts. Fire ants occur most commonly in open areas with soil disturbance that are wet or near water. The pests were introduced from South America around 1930, at the port of Mobile, AL (Vinson and Sorensen 1986). By the early 1980s, they occupied most of Mississippi, Louisiana, Florida, Georgia, and South Carolina, and parts of North Carolina, Tennessee, Arkansas, Oklahoma and Texas (Canter 1981). Fire ants prey on a number of vertebrate and invertebrate species. At E glin $A F B$, they prey upon turtles and other reptiles that lay their eggs along roads and powerlines. Fire ants also commonly prey upon other reptiles, arthropods, and some birds and mammals (reviewed by FNAI 1994b).

Management recommendations. Fireants can becontrolled with several over-thecounter insecticides (e.g., AMDRO [American Cyanamid Company, Wayne, NJ ]), but the effects these chemicals have on other vertebrates and invertebrates is unknown. Fire-ant control apparently was successful in increasing Northern bobwhite quail (Colinus virginianus) populations in Texas (Allen, Lutz, and Demarais 1995; see this source for references).

\section{Southern Pine Beetle}

Impacts. Forest management practices, such as dense stocking of pine, have increased susceptibility of forests to outbreaks of southern pine beetle (Dendroctonus frontalis), which naturally occur in pine forests at low population levels. However, the populations have the potential to reach infestation levels. Mature trees with large boles and bark surface area provide ideal habitat for the southern pine beetle. Longleaf and slash pine are more resistant to infestations than is loblolly. Common characteristics of high hazard stands are dense stocking and slow radial growth rates. Disturbances such as lightning strikes, recent logging activity, wind damage, and flooding can compound beetle problems (Belanger, H edden, and Lorio 1993).

Management recommendations. Management strategies toreducelosses from the southern pine beetle were given in Belanger, Hedden, and Lorio (1993). 
Recommended measures that will also improve habitat for native species are: (1) to increase the spacing between trees (because it el iminates extensive competition among trees for resources, and because wide spacing limits beetle spread), and (2) to convert sites to more resistant pine species (e.g., longleaf pine [within its range]). Other suggestions of Belanger, Hedden, and Lorio (1993) to reduce losses from southern pine beetles are not recommended for TES habitat management (e.g., allowing for mixed pine-hardwood stands and using shorter rotations), as these methods will not improve or maintain habitat for native TES species.

Rather than using pesticide, J . J ackson (pers. comm., 1995) believes that southern pine beetle infestations can often be controlled naturally (e.g.,with relatively low tree densities in Iongleaf pine forests). Under certain conditions, the beetles affect one or two trees, and do not become problematic. J ackson recommended that managers leave the infested trees alone, unless they are near RCW cavity trees. On the other hand, experience in some forests has demonstrated that pine beetle outbreaks do not die out naturally while pine trees are accessible (Fort Polk anonymous reviewer, 13 August 1996). The Eglin AFB Natural Resource Management Plan recommended cutting trees but not spraying them with pesticide; the cut trees can be left or removed, but methods to minimize soil

disturbance are preferred. Immediate measures to prevent soil erosion after pine beetle control should then be taken, if needed (Dept. of the Air Force 1993).

A promising area of bark beetle research being conducted by the USDA Forest Service and several universities in the Southeast involves the use of biopesticides (reviewed in Strom, Goyer, and Hayes 1995). The naturally occurring chemical known as 4-AA (4-allylanisole or estragole) is found in certain pines and other plants. Laboratory studies indicated a high percentage of pinebeetles were repelled by the presence of 4-AA. More importantly, in limited field studies, 4-AA proved effective in preventing infestation of lightning-struck trees, which are highly susceptibleto pine beetle infestation. Similar results were obtained when 4-AA was applied to 300 RCW cavity trees in national forests in Mississippi, Louisiana, and Florida (reviewed in Strom, Goyer, and Hayes 1995).

\section{Brown-spot Needle Blight}

Impacts. Fire suppression increases susceptibility of Iongleaf pine seedlings to brown-spot needle blight, a fungus that affects the seedlings during the grass stage. It is the worst disease affecting grass-stage longl eaf pine seedlings, and it becomes more intense following canopy removal. The blight is unlikely to reach serious levels in stands retained under a pine overstory (Boyer 1993). The disease can be 
recognized by the distinct brown spots it produces on pine needles; the spots are typically bordered by yellow bands (Dixon et al. 1991).

Management recommendation. Prescribed fire is recommended to control brownspot needle blight (Dept. of the Air F orce 1993).

\section{Exotic or Pest Plants}

Impacts of cogon grass. Cogon grass (Imperica cylindrica) has been designated the worst perennial grass weed of southern and eastern Asia and one of the 10 worst weeds worldwide. It has been documented in Louisiana, Mississippi, Alabama, South Carolina, and Florida (reviewed in Coile and Shilling 1993), and now occurs on Eglin AFB. It is capable of dominating the understory of pinelands, to the exclusion of other species (FNAI 1994b). It also becomes established in scrubs (USFWS 1995). This species can survive in dry, barren areas where other plants have difficulties, because it has a root system efficient at extracting water and minerals (Coile and Shilling 1993). The spread of cogon grass cannot be controlled using fire (Duever 1989).

Cogon grass is spread by wind-dispersed seed and by rhizomes, which can betransported on equipment (e.g., bulldozers; FNAI 1994b; USFWS 1995). Rhizomatous spread and allelopathy (production of chemicals that inhibit the growth of other plants) aid the species in attaining 100 percent cover in many areas (Coile and Shilling 1993).

In Florida, cogon grass can be observed growing al ong roadsides, usually in full sun, forming densestands of yellow-green grass. A quick identification feature is an offcenter midrib, which is whitish. This feature is more apparent toward the tips of the leaves. Other features are translucent, dry, rough leaf margins (similar to cutgrass [Lersia spp.]) and the presence of many scale-like nongreen leaves on the rhizomes (similar to] ohnsongrass [Sorghum hal epense]). Plants are usually about 1-m (3-ft) tall, but can rarely grow to 3-m (10-ft) tall, and are similar in appearance tof ohnsongrass.

Impacts of love grass. Love grass, a weed found in waste places (Radford, Ahles, and Bell 1968), is invading sandhills at F ort Bragg. This species is carried into sites or washed in with rains. It seeds readily after a burn (J . Shipley, pers. comm., 1996).

Other plant invaders. Other plant invaders in sandhills are lantana (Lantana camara) and camphor tree (Cinnamomum camphora) (USF WS 1995). Undisturbed 
and disturbed moist pineflatwoods in South Florida have been extensively invaded by melaleuca (Melaleuca quinquenervia), Brazilian pepper (Schinus terebinthifolius), and downy myrtle (Rhodomyrtus tomentosus; Abrahamson and Hartnett 1990). Both melaleuca and Brazilian pepper are considered serious threats to the ecosystems of South F lorida (G. J ubinsky, pers. comm., 1995).

Management recommendations. Managers should obtain a copy of Exotic Woody Plant Control (Langeland 1990) for information regarding control of exotics. ${ }^{*}$

It is imperative to quickly eradicate fierce competitors, such as cogon grass, upon first appearance. After such species begin to spread, efforts to remove them become costly. In general, manual removal of exotics should cause the least disturbance to the environment, if done carefully. However, manual removal can be labor intensive and may not work for some species (e.g., cogon grass). When using manual methods, every effort must be made to remove the entire root system, because a 6.3-mm (1/4-in.) section of root can resprout (Langeland 1990). Only manual removal is desirable in Type I sites, unless it is determined that more intensive methods (e.g., chemical removal) are absolutely necessary to eliminate exotic or pest plants, and that the pest plants pose a greater risk to the TES habitat than do the control methods. Manual removal is also the preferred method in Type II sites.

Mechanical removal (e.g., using bulldozers, specialized logging equipment) should not be used in natural areas, because it causes severe disturbance to soils and nontarget vegetation. Mechanical removal should be used when an area is being cleared for new land use. Mechanical removal also requires follow-up treatment, as exotics will be quick to reinvade (Langeland 1990). Mechanical removal should be considered appropriatein TypelII and IV sites. In these cases, least disturbance methods should be used, and wetland protection and erosion measures should be taken.

Herbicides have been used successfully to remove woody exotics, but should be avoided within or immediately adjacent to TES habitat or any permanent or seasonal wetlands. Herbicides can affect water quality and present a direct threat to rare species (Russo et al. 1993; USFWS 1983). They should not be used to control exotics in Type I sites, and should not be used in Type II sites unless removal over large areas is needed and not feasible through manual methods.

\footnotetext{
This publication can be obtained by contacting C.M. Hinton, Publications Distribution Center, IFAS Building 664, University of Florida, Gainesville, FL 32611.
} 
Since certain exotics pose a very serious threat to TES populations, herbicides may need to be used if manual methods are insufficient.

If herbicides must be applied, methods and timing should minimize effects on nontarget vegetation and the environment. The herbicide applicator must be well informed of thechemical properties of the herbicide, and under what circumstances it should be applied. Environmental precautions are stated on the herbicide label.

In general, these guidelines should be followed:

- Only the minimum recommended amount should be used (Dept. of the Air Force 1993).

- Herbicides should not be applied aerially in TES habitat. Use only directapplication techniques, such as spot treatments, to ensure the herbicide contacts only target plants.

The applicator also should be aware of potential weather conditions and schedule applications accordingly (Langel and 1990):

- Heavy rainfall following application may result in damage to nontarget vegetation. On the other hand, drought conditions preceding application can affect herbicide efficacy, because drought-stressed plants are less likely to absorb herbicides.

- $\quad$ Excessive wind may result in poor coverage to target vegetation and cause drift that results in damage to nontarget vegetation. Excessive wind also can indirectly reduce the ability of the plant leaves to absorb herbicides.

- At less than optimum temperatures, plant growth slows down, which may decrease herbicide absorption or activity.

Specific recommendations for management of cogon grass were provided by Coile and Shilling (1993):

Managers are advised to refer to the control measures in the IFAS publication “Cogon grass (I mperata cylindrica (L.) Beauv.) Biology, E cology and Control in Florida" by Colvin et al. 1994. Glyphosate (Accord or Roundup)* or imazapyr

\footnotetext{
* Using glyphosate to control Cogon grass will eliminate wiregrass and associated species in the process (in Duever 1989). Since glyphosate and imazapyr are both broad spectrum herbicides, they will kill all or most plants that they come into contact with. Thus, care must be taken to avoid damage to nontarget, desirable vegetation (Langeland
} 
(Arsenal) are probably the best herbicides to control Cogon grass where they can be applied. Several treatments are necessary for effective control. The dead leaves of Cogon grass remain upright and do not decay easily, and these prevent herbicides from being effectively absorbed. For effective control, herbicide should be applied to living, green leaves, which will allow transport to rhizomes. Late fall is the best time to apply herbicides because plants are sending carbohydrates to roots and rhizomes for storage, and at this time the herbicide will also be translocated to rhizomes. Killing of rhizomes is necessary to control Cogon grass. It is essential to apply a herbicide after cultivation or burning.

\section{Fertilization}

Impacts. Fertilization in pine flatwoods, sandhills, and scrub may have drastic effects on these communities because they are naturally low in nutrients, and weedy species are likely to invade following nutrient enrichment. Sand pine scrub communities appear to be structured by nutrient stress (Myers 1990). Several studies compared combined effects of fertilization and sitepreparation, and showed that these practices lead to drastic changes in vegetation structure and composition (Swindel , Conde, and Smith 1982; Moore and Swindel 1981), but these studies havenot examined fertilization al one. Swindel, Conde, and Smith (1989) conducted studies on plant community responses to various treatments in pine flatwoods and found that species richness tended to be reduced by fertilization. They attributed this response to increased shading of the understory by larger pine trees on fertilized plots. In another study at a savanna site, applications of phosphates at the time of planting young slash pine also lead to the development of a dense canopy. Needle fall from the dense canopy suppressed the ground cover (including wiregrass). Woody species such as gall berry, hollies, and wax myrtle became more vigorous; St.J ohn's-wort diminished (reviewed in Brown, Stone, and Carlisle 1990). Walker and Peet (1983) reported that fertilization in annually burned mesic savannas doubled peak standing crop the following summer, but nofurther increase was observed after four seasons of fertilization. Fertilization in a low fire-frequency mesic site resulted in a much smaller increase in productivity (Walker and Peet 1983). Thill and Bellemore (1986) found that the combination of fire suppression and a one-timeapplication of custom-designed fertilizer for pines led to a short-term increase in pinehill bluestem (Schizachyrium scoparium var. divergens) standing crop, which formed a thick mat of litter and smothered subsequent herbaceous growth. Over the first 2 years post-treatment, rayless goldenrod (Bigelowia nuttall lii) 
and the beakrushes (Rhynchospora spp.) declined in coverage, although trends were not analyzed statistically (Thill and Bellemore 1986). Over a subsequent 12-yr study (Haywood and Thill 1995), the composition of dominant woody species did not change, the planted pinespecies increased in canopy cover and leaf size, and several herbaceous species showed a declining trend in frequency-the threeawn grasses (Aristida spp.), low panicums, cutover muhly, fringerazorsedge(Scleria ciliata), and the stargrasses (Aletris spp.). The following species either increased in frequency or remained common: slender bluestem, pineywoods dropseed, pinehill bluestem, beakrushes, rayless goldenrod, Cladonia dimorphoclada (a lichen), spikemosses (Sel aginella spp.), narrowleaf silkgrass, and shiny gol denrod (Solidago nitida). Fire suppression probably had more influence on observed changes over the 12-yr study period than did the initial fertilization treatment.

Fertilization may be intended, or may result inadvertently from activities in the surrounding landscape. Fertilizer that runs off into aquatic habitats can contribute to eutrophication (e.g., algal blooms). Larval flatwoods salamanders are noticeably absent from fertilizer-impacted wetlands (Palis 1996). Table 8 lists several activities that can lead to increased fertility in this community.

Management recommendations. Avoid fertilizer use within or adjacent to Type I or II TES habitat sites that support a native ground cover. In all cases, fertilizers should be used with care, to assure that they will not enter wetlands. Effects of foam fire retardants on vegetation and fauna should be monitored (see Fire Prevention, $p$ 40). 


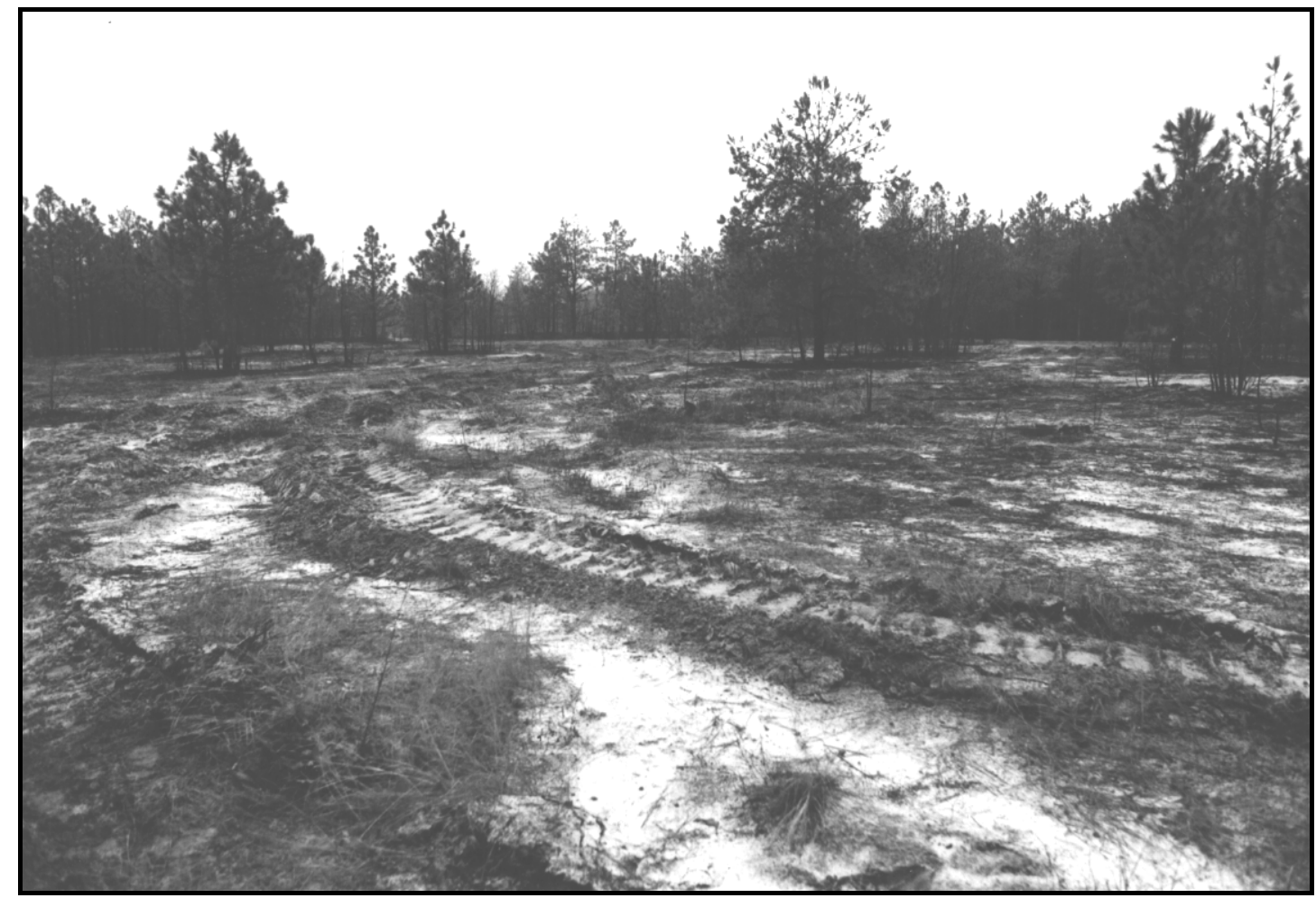

Figure 4. Occupational (bivouac) sites, assembly areas, and tank maneuver areas become barren, which fragments fuel sources and prevents fire spread over large areas.

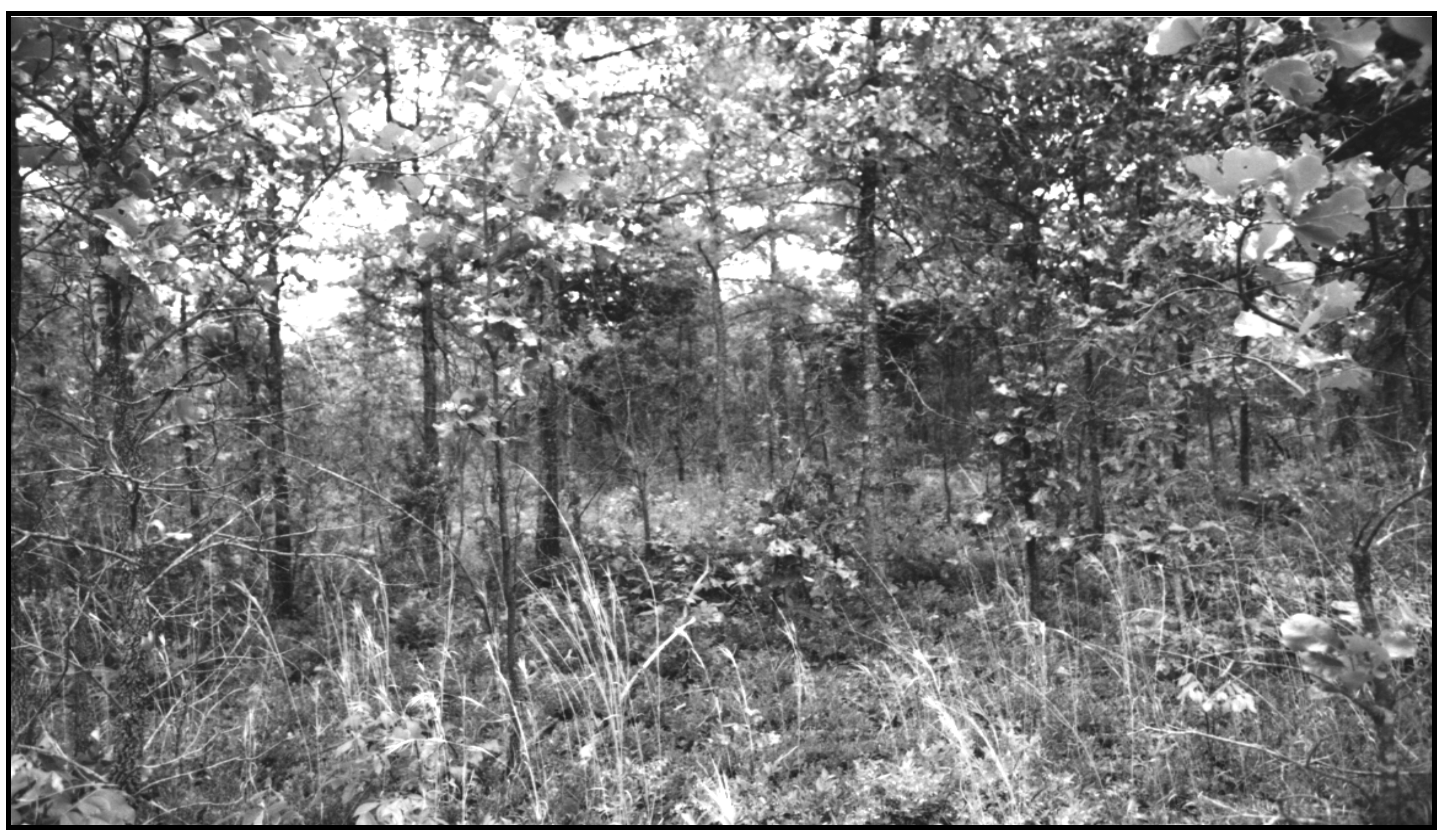

Figure 5. Early stages of woody species invasion due to infrequent burning in a sandhills community. 


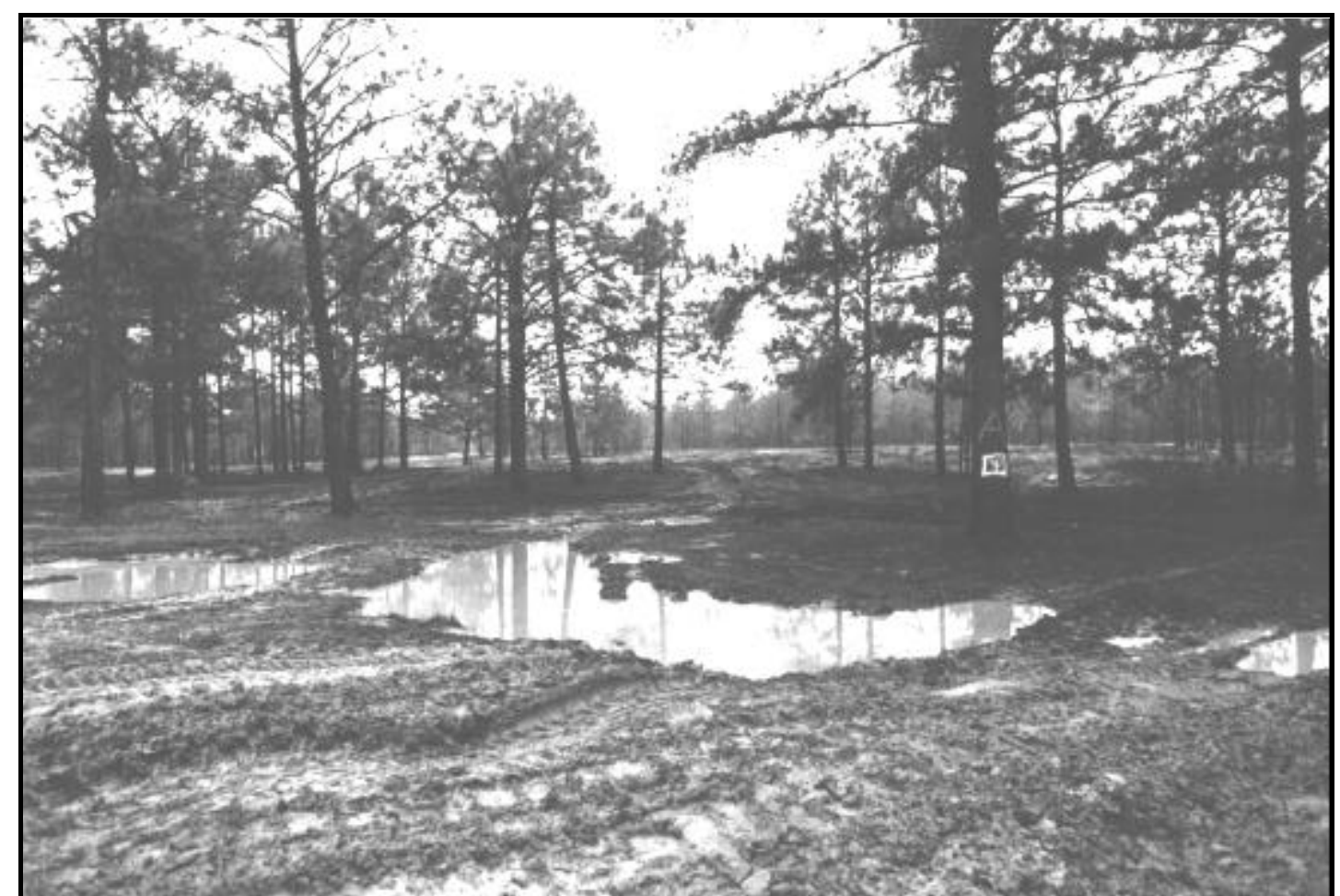

Figure 6. Heavy vehicle use leads to altered hydrology. Normal sheet flow becomes disrupted as ponding occurs as a result of changes in soil structure.

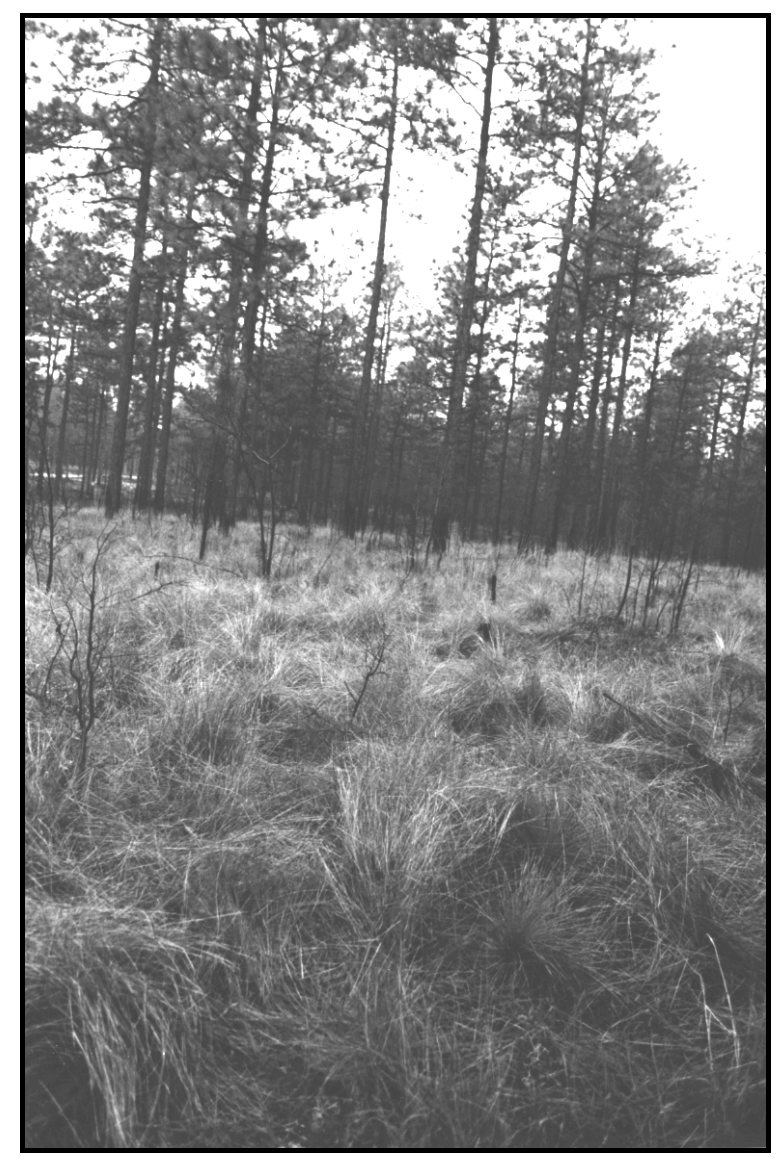

Figure 7. Dense stand of wiregrass in sandhills community. 


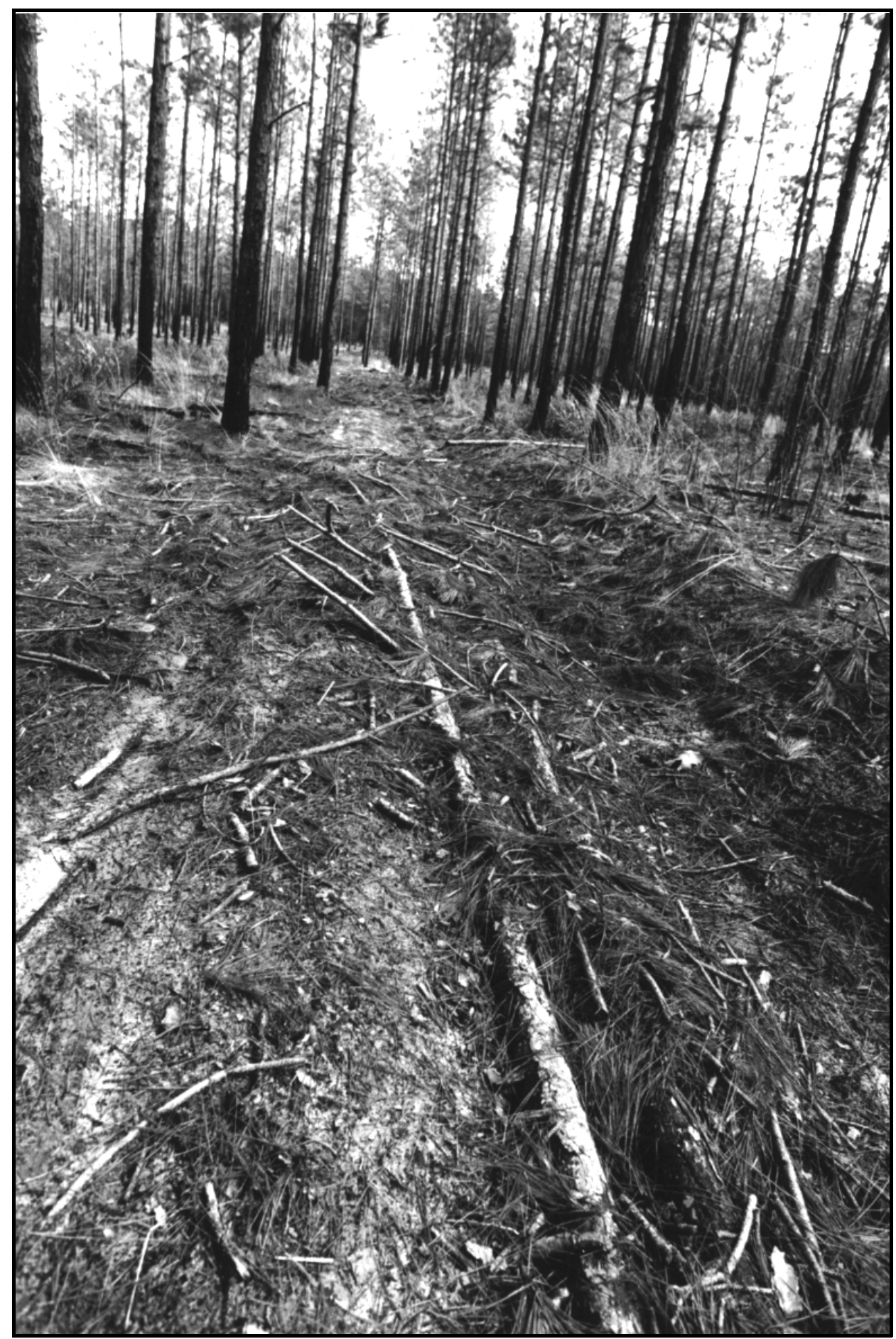

Figure 8. Soil disturbance from mechanical timber operations. 


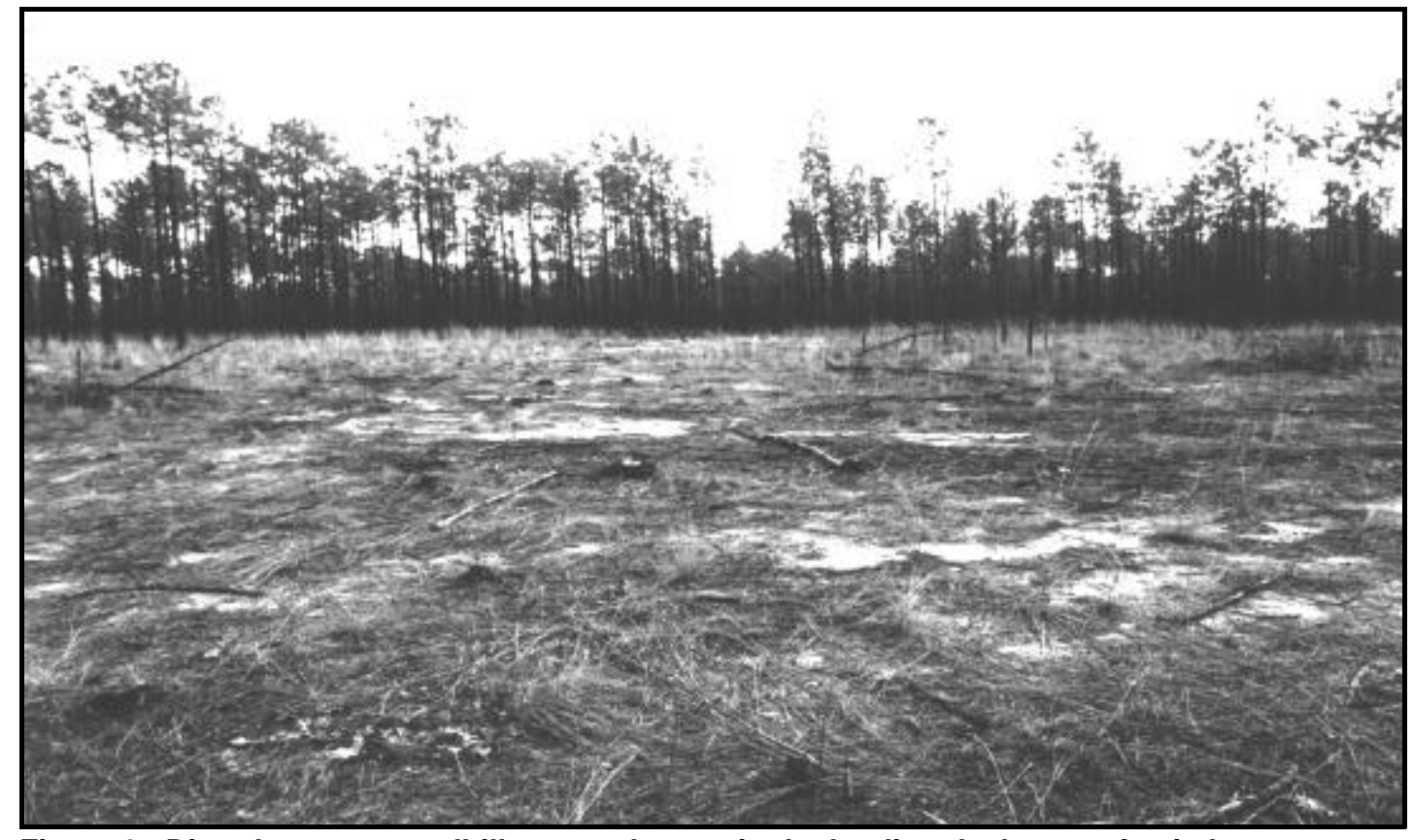

Figure 9. Disturbance to sandhills ground cover in the loading deck area of a timber operation.

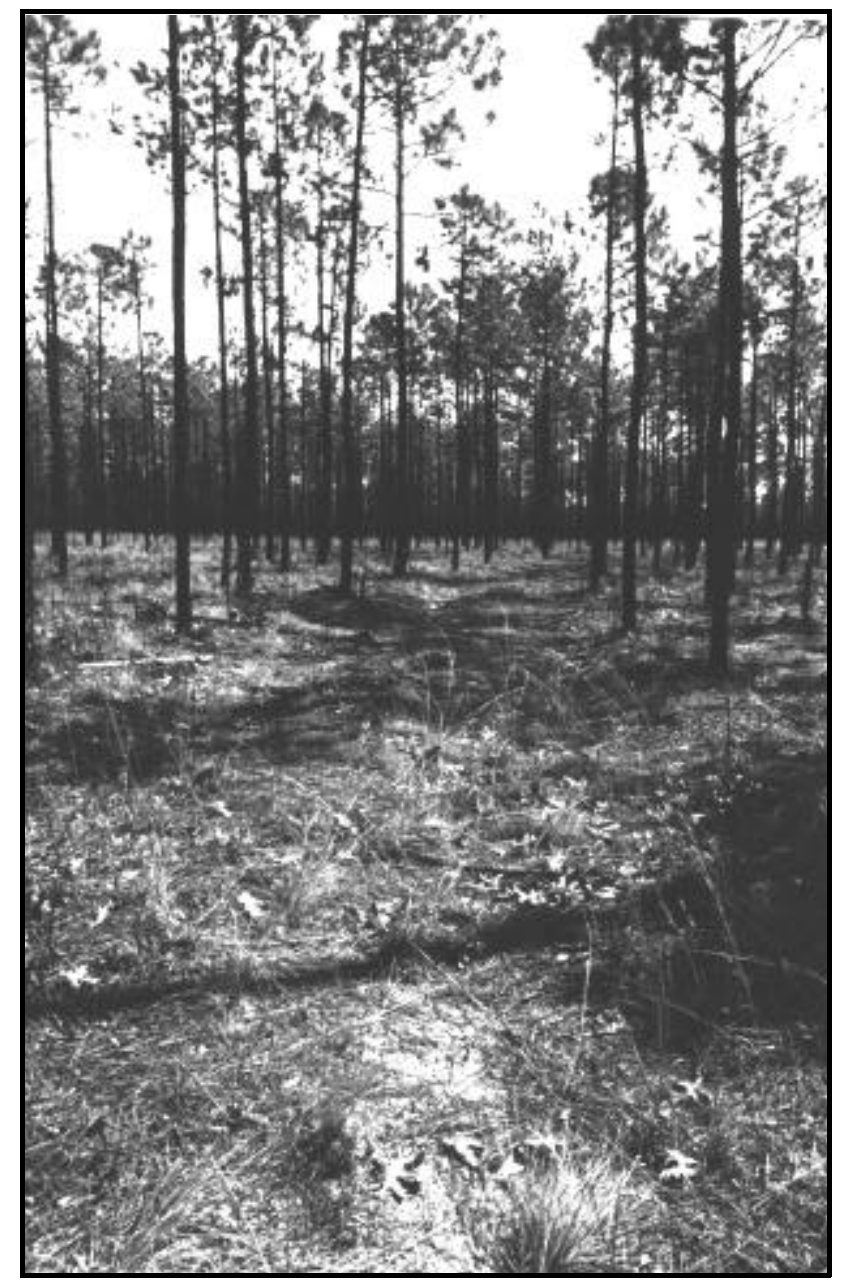

Figure 10. Some ground cover (e.g., wiregrass)

remains intact after logging operations. 


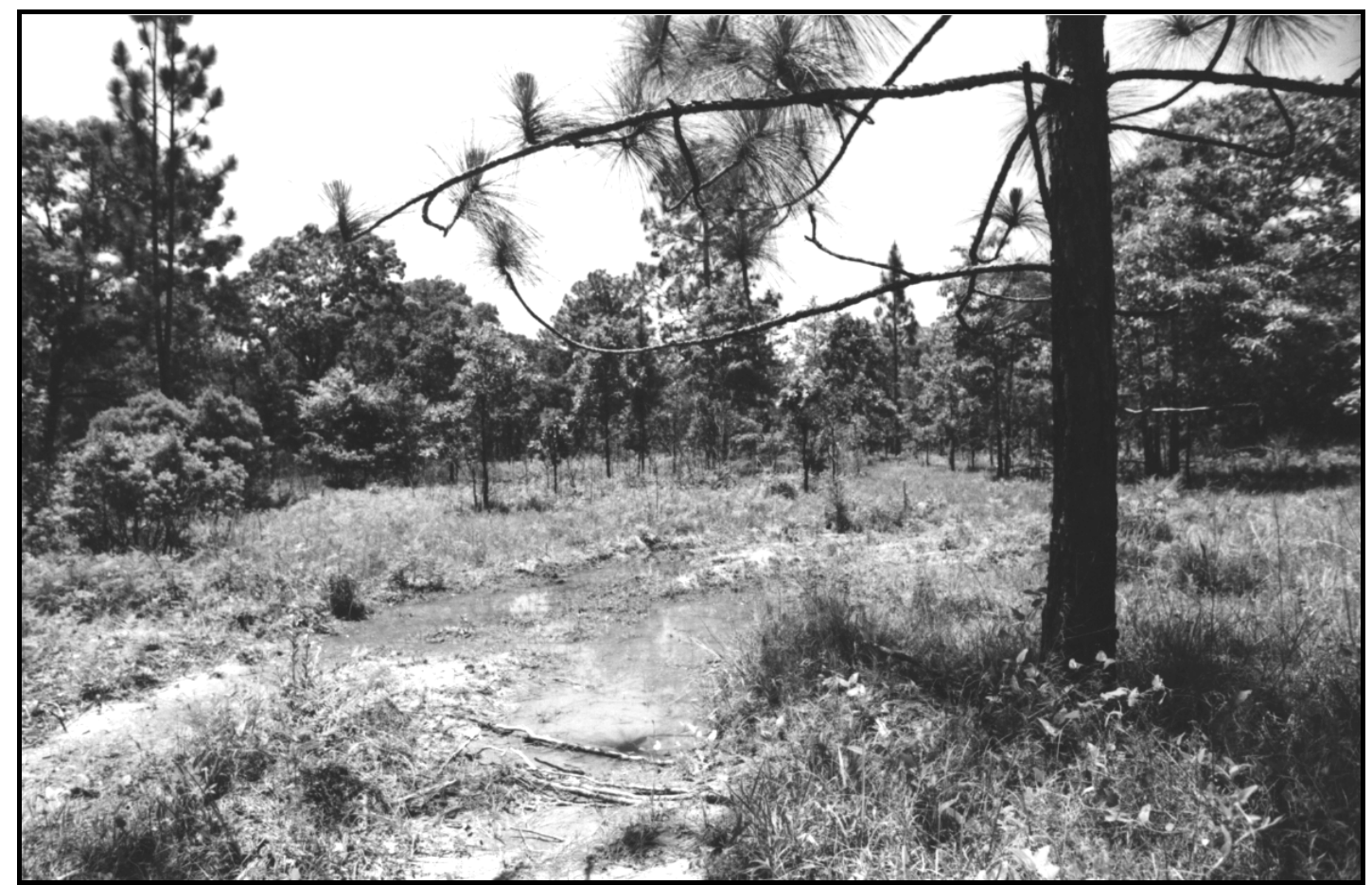

Figure 11. Off-road tank traffic in this flatwood community led to rutting, ponding, fire suppression, and consequential changes in the composition and structure of the community.

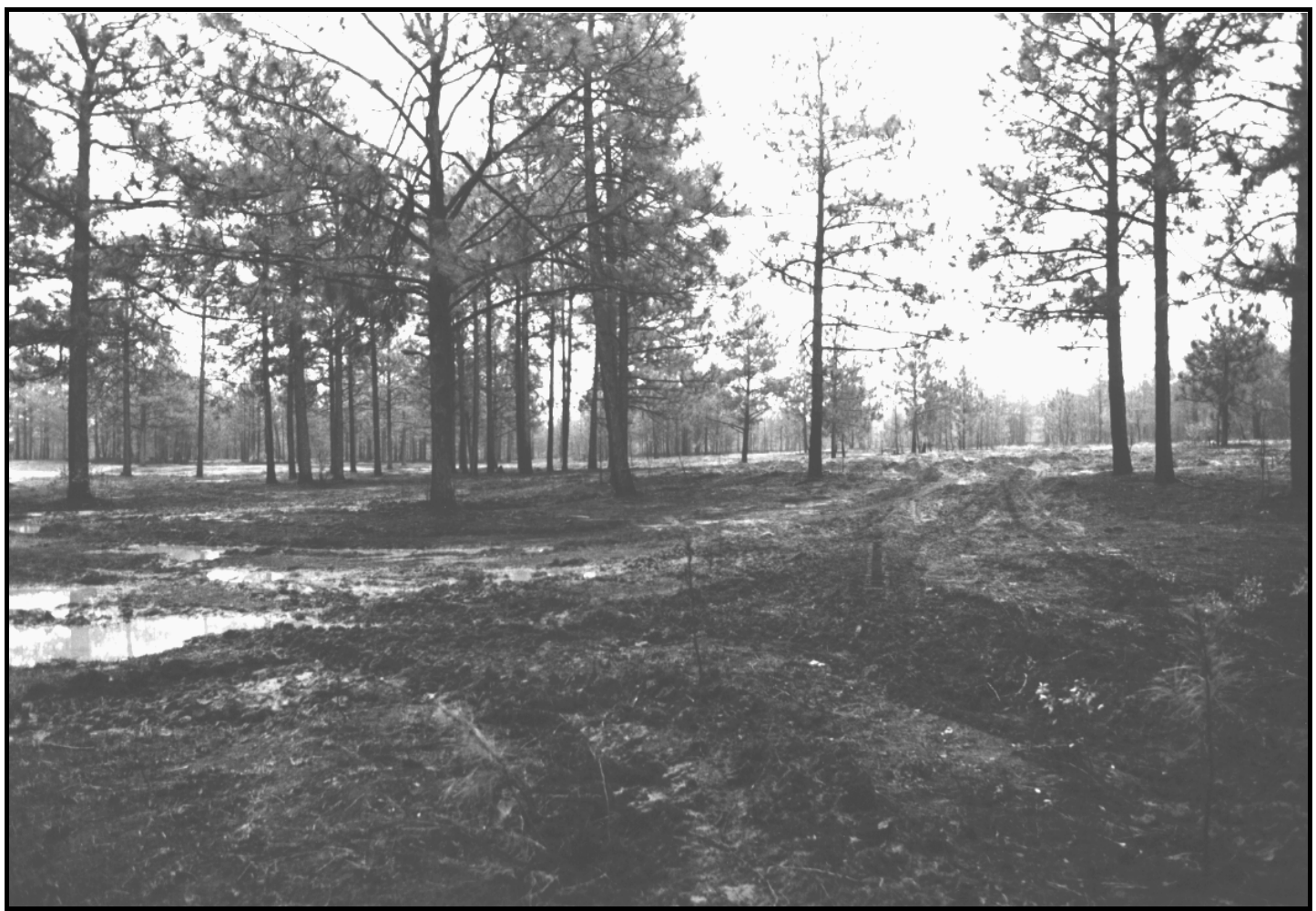

Figure 12. Damage to soils, ground cover, and woody regeneration typical of intensively used staging or assembly areas. 


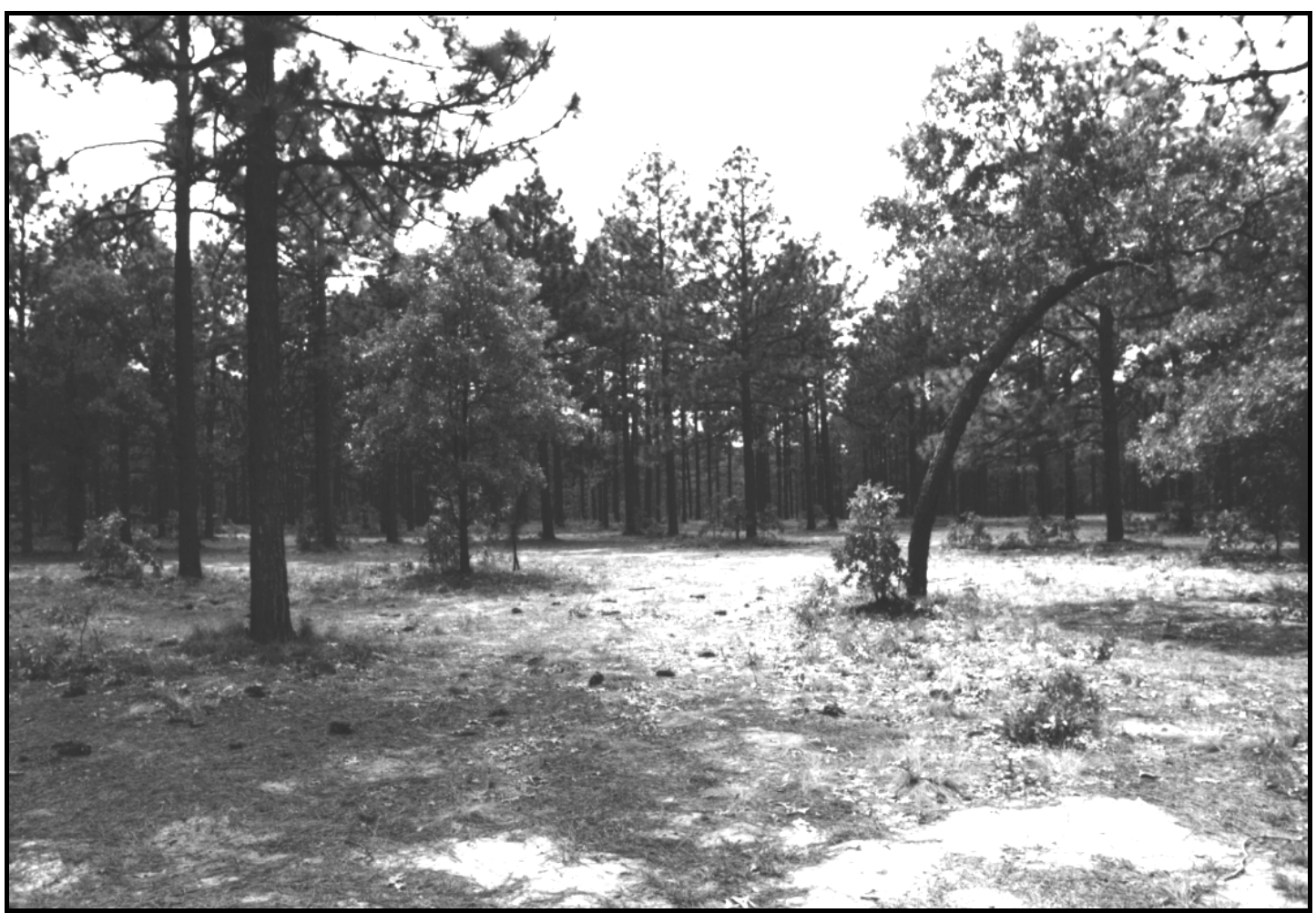

Figure 13. Damage to soils (compaction), ground cover, and overstory trees typical of intensively used occupation (bivouac) sites.

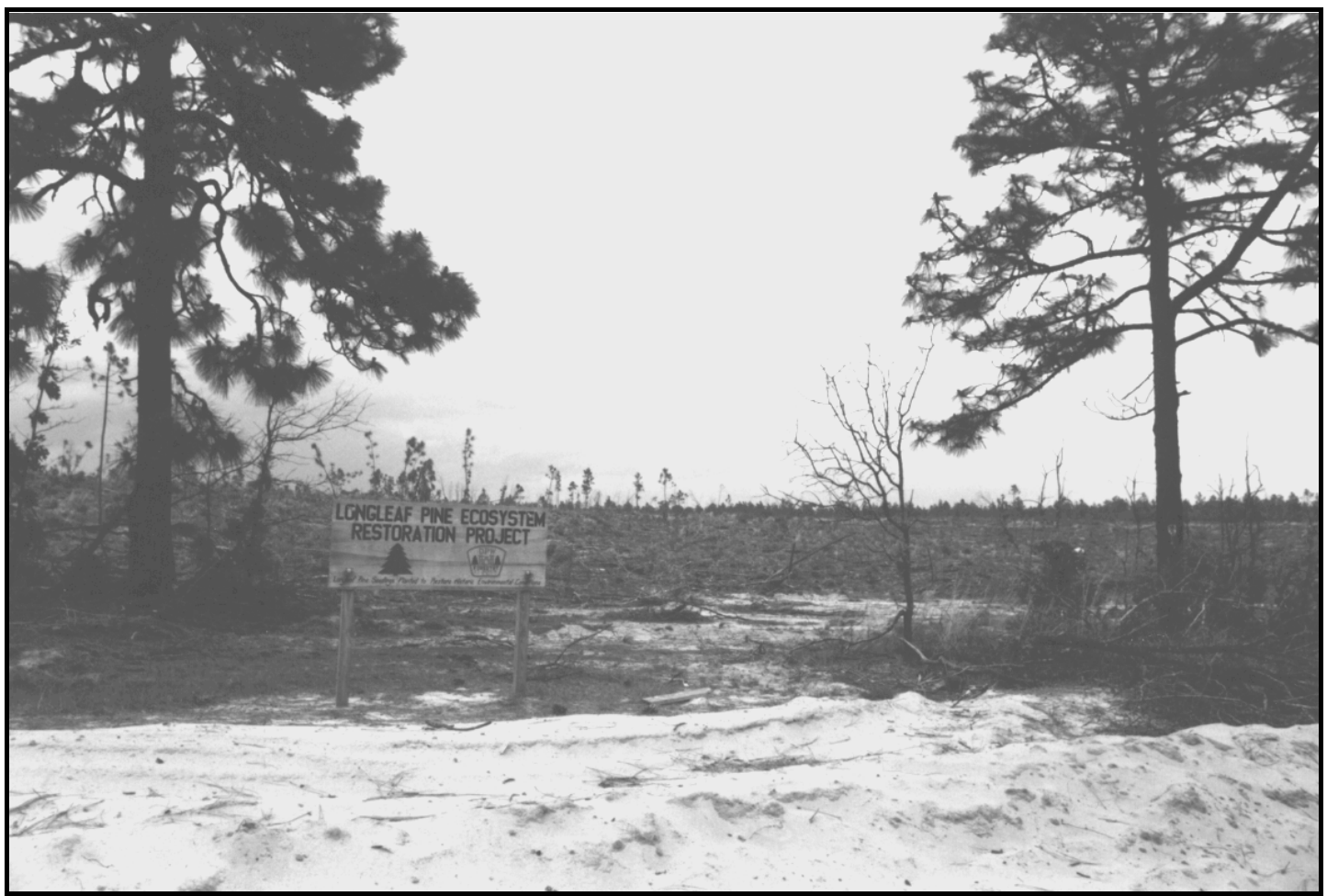

Figure 14. Longleaf pine restoration project on Fort Jackson, SC. 


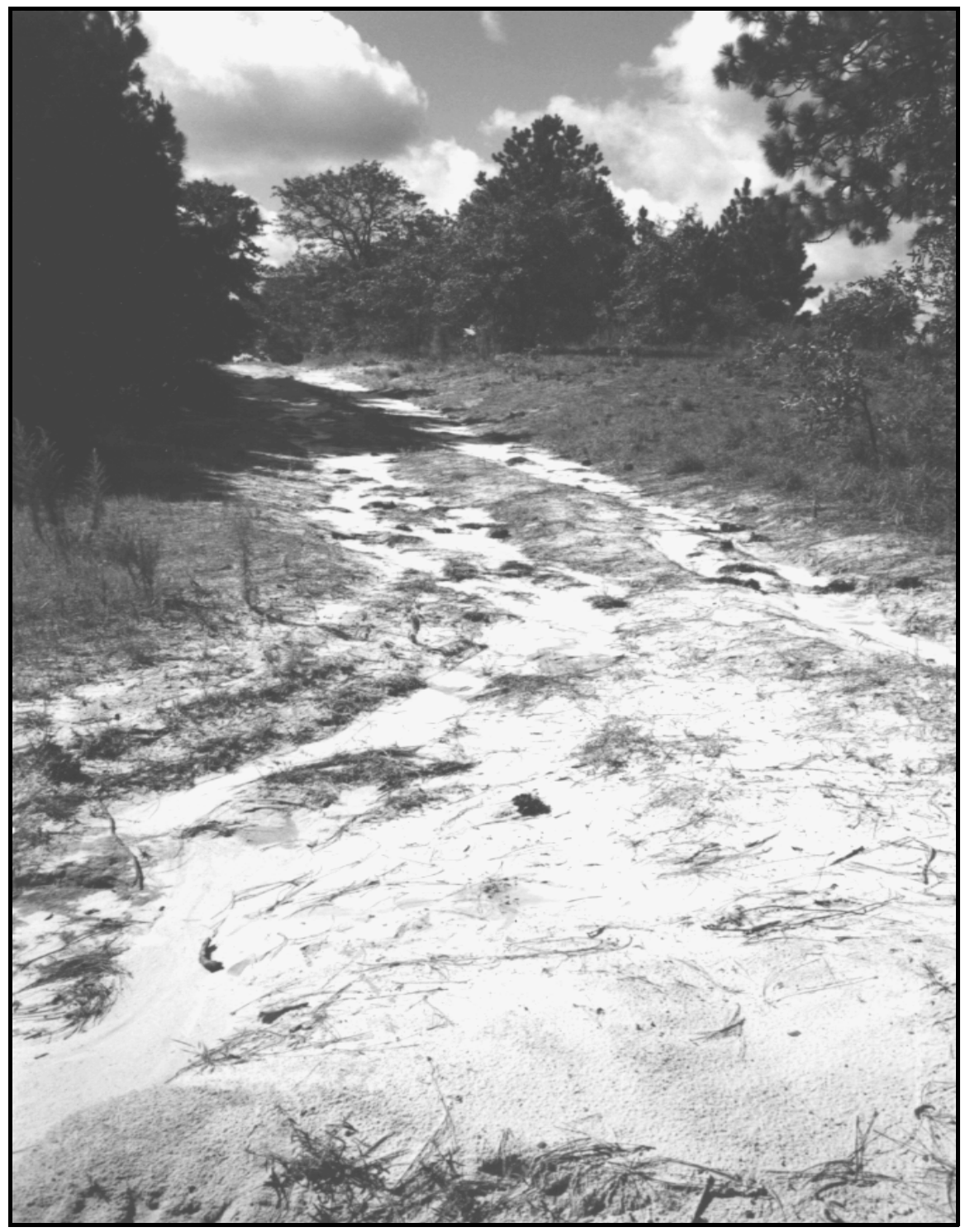

Figure 15. Erosion on sandy, sloped soils usually leads to gully erosion. 


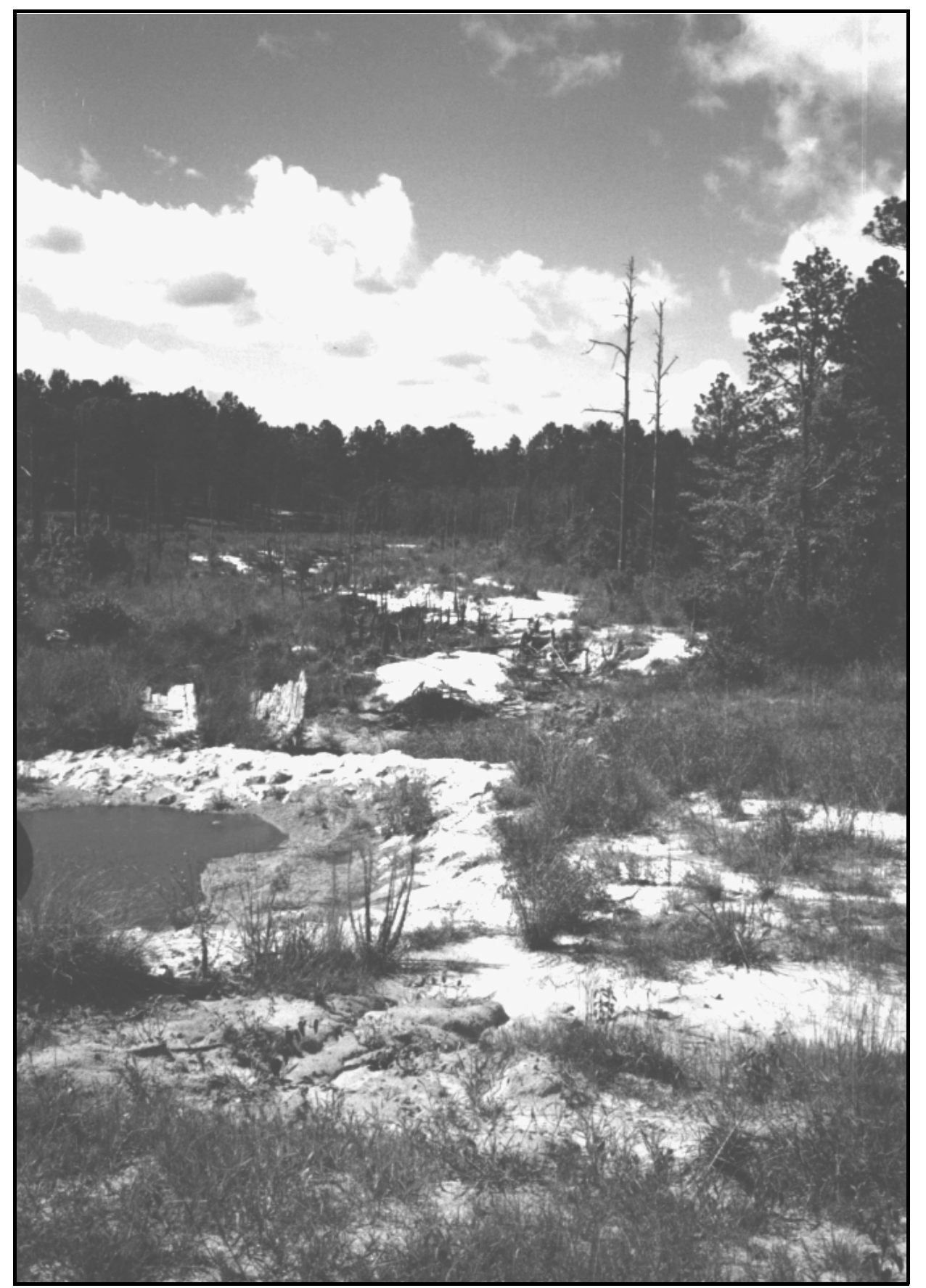

Figure 16. Severe sedimentation into a natural stream caused by intensive tank maneuvers in nearby upland areas. 
Table 4. Activities that lead to fire suppression in longleaf pine communities.

\begin{tabular}{|ll|}
\hline \multicolumn{1}{|c|}{ Activity(ies) } & \multicolumn{1}{c|}{ Effect(s) } \\
\hline Land conversion & Fragments landscape so wildfires cannot spread over large areas. \\
Creation of ditches, plowlines & Fire exclusion. \\
$\begin{array}{l}\text { Fire suppression, or alteration in } \\
\text { frequency, season }\end{array}$ & $\begin{array}{l}\text { In the long term, this leads to natural fire suppression by favoring plant } \\
\text { species which neither tolerate nor facilitate the spread of fire. }\end{array}$ \\
$\begin{array}{l}\text { Pine straw harvest in flatwoods and } \\
\text { sandhills }\end{array}$ & $\begin{array}{l}\text { Actively removes fuel, can prevent low intensity fire (Russo et al. 1993), } \\
\text { or can reduce the effectiveness and coverage in areas that do burn (M. }\end{array}$ \\
Schafale, pers. comm.). \\
Presence of troops in field & $\begin{array}{l}\text { Precludes access and opportunity for prescribed burns due to safety } \\
\text { concerns (although troops often start fires as well and thus benefit TES } \\
\text { habitat). }\end{array}$ \\
$\begin{array}{l}\text { Use of heavy equipment for site } \\
\text { preparation or military vehicles in } \\
\text { flatwoods and sandhills }\end{array}$ & $\begin{array}{l}\text { Disturbs the upper soil horizon and reduces bunchgrass cover, removing } \\
\text { fuel. }\end{array}$ \\
\hline
\end{tabular}

Table 5. Activities that alter the hydrology in wetland inclusions within pine flatwoods and sandhills.

\begin{tabular}{|c|c|}
\hline Activity & Potential Effect \\
\hline $\begin{array}{l}\text { Creation of fire plowlines, } \\
\text { scrapes, roadside ditches, } \\
\text { excavations }\end{array}$ & May channel water away from the community. \\
\hline Bedding for plantations & Permanently raises the soil surface so that it no longer becomes saturated. \\
\hline $\begin{array}{l}\text { Use of heavy equipment } \\
\text { and military vehicle maneuver } \\
\text { training (Figure 6) }\end{array}$ & $\begin{array}{l}\text { Wheel ruts can provide microsites for more hydrophytic species, while ridges } \\
\text { may be invaded by more xerophytic species than would normally occur. } \\
\text { Rutting in wet areas (possibly in or adjacent to bog inclusions or ecotones) may } \\
\text { channelize natural groundwater sheet flow, so the surrounding wetland area } \\
\text { dries out and no longer supports rare wetland species (R. Stewart, pers. } \\
\text { comm., 1995; and M. Harper and A. Trame, pers obs.). In addition, there are } \\
\text { indirect effects from soil compaction (see Soil Compaction) such as reduced } \\
\text { hydraulic conductivity or inhibited subsurface groundwater flow (Aust et al. } \\
\text { 1993). }\end{array}$ \\
\hline $\begin{array}{l}\text { Intensive foot training/ } \\
\text { occupational exercises, livestock } \\
\text { grazing }\end{array}$ & $\begin{array}{l}\text { Compacts soil, causing decrease in water infiltration and percolation through } \\
\text { soil, which can cause increased surface runoff and altered water regimes (see } \\
\text { Soil Compaction). }\end{array}$ \\
\hline Clearcutting, harvesting activities & $\begin{array}{l}\text { Reduced evapotranspiration, caused by clearcutting and harvesting, increases } \\
\text { soil moisture. }\end{array}$ \\
\hline Pinestraw harvest & $\begin{array}{l}\text { Reduction in gravimetric soil moisture following a single episode of litter removal } \\
\text { may cause decreased growth in longleaf pine seedlings during the first year } \\
\text { following pinestraw raking (Kelly and Wentworth 1993). }\end{array}$ \\
\hline Fire suppression & $\begin{array}{l}\text { Leads to increased moisture by allowing litter, which holds moisture, to } \\
\text { accumulate; leads to changes in plant biomass and organics. Changes } \\
\text { community composition, which can lead to breakdown in hardpan. }\end{array}$ \\
\hline
\end{tabular}


Table 6. Native plant species that have potential for erosion control plantings in longleaf pine woodlands.

\begin{tabular}{|c|c|}
\hline Common Name ${ }^{a}$ & Scientific Name \\
\hline \multicolumn{2}{|l|}{ Grasses } \\
\hline Bluestem, Big & Andropogon gerardii \\
\hline Bluestem, Broom Sedge ${ }^{b}$ & Andropogon virginicus \\
\hline Bluestem, Chalky & Andropogon capillipes \\
\hline Bluestem, Pinehill & Schizachyrium scoparium var. divergens \\
\hline Bluestem, Slender & Schizachyrium tenerum \\
\hline Carpetgrass, Common & Axonopus affinis \\
\hline Indiangrass & Sorghastrum nutans \\
\hline Maidencane ${ }^{c}$ & Panicum hemitomon \\
\hline Panicum, Beaked & Panicum anceps var. rhizomatum \\
\hline Purpletop & Tridens flavus \\
\hline Switchgrass & Panicum virgatum \\
\hline Wild Rye, Virginia & Elymus virginicus \\
\hline Woodoats, Slender & Chasmanthium laxum var. sessiliflorum \\
\hline \multicolumn{2}{|l|}{ Legumes } \\
\hline Sleepingplant & Chamaecrista fasciculata \\
\hline Tephrosia, Virginia & Tephrosia virginiana \\
\hline Ticktrefoil & Desmodium spp. \\
\hline \multicolumn{2}{|c|}{$\begin{array}{l}\text { Note: Nomenclature follows the NRCS PLANTS National Database as of } 30 \text { May } 1997 \\
\text { (http://plants.usda.gov/plants). } \\
\text { aD. Lane, pers. comm., except where noted otherwise. } \\
\text { bR. Hansard, pers. comm., } 1995 . \\
\text { 'G. Tanner, pers. comm., } 1996 .\end{array}$} \\
\hline
\end{tabular}


Table 7. Activities that may lead to invasion of pine flatwoods and sandhills by species not native to the community.

\begin{tabular}{|ll|}
\hline \multicolumn{1}{|c|}{ Activity(ies) } & \multicolumn{1}{c|}{ Effect(s) } \\
\hline Hog rooting & $\begin{array}{l}\text { Destroys vegetation and churns up soil, freeing resources for the } \\
\text { establishment of exotics. Feral hogs may also be responsible for } \\
\text { transporting nonnative propagules into the community. }\end{array}$ \\
Adding fill dirt & May add nutrient-rich soil into a nutrient-poor community, altering \\
competitive regimes. Propagules of invasive plants can be transported in \\
the fill.
\end{tabular}

Table 8. Activities that could lead to artificially increased fertility in pine flatwoods and sandhills.

Fertilization during site preparation (Frost, Walker, and Peet 1986), nutrient runoff from fertilization in adjacent upland communities (Dept. of the Army 1994), or fertilization accompanying revegetation activities.

Breakdown of some foam fire retardants to phosphorous (R. Stanton, pers. comm., 1995). Because flatwoods soils are generally phosphorous-deficient (Clewell 1989), this breakdown may pose a nutrient enrichment problem.

Input of fine nutrient dust from fertilized agricultural fields (Frost, Walker, and Peet 1986).

Smokestack output from burning fossil fuels (Frost, Walker, and Peet 1986).

Nutrient fixation by automobile engines (Frost, Walker, and Peet 1986). 


\section{Summary}

Natural longleaf pinewoodland communities in the southeastern United States are biologically diverse, providing habitat for at least four Federally endangered plant species, four F ederally listed animal species, and dozens of candidates for protection under the ESA. These same ecosystems also support the DoD military mission, forest commodity programs, and other land uses, (e.g., recreation) on DoD installations. In some circumstances, it is desirable to maintain high-quality natural communities to provide habitat for multiple native species over largeareas. In particular, this strategy works well as part of the Integrated Natural Resources Management Planning (INRMP) process, within an ecosystem management framework. Therecommendations made in this report are intended to beapplied in areas where TES conservation is the main focus of land management, but where other activities, especially military training, are desired to the maximum extent possible. This report is intended to hel p managers balance potentially conflicting land uses. Other management choices areappropriate in areas whereTES management is less desirable than military training or forest products production.

It is beneficial to manage TES habitat using an ecosystem-based approach; land-use objectives combined with knowledge of ecosystem processes can help identify the appropriate management techniques for each landscape and each site. Common goals for ecosystem management of TES habitat include the maintenance of natural community composition, structure, and function. Longleaf pine dominates the canopy in both sandhills and flatwoods, except in some parts of Florida, where slash pine becomes important, and in eastern Texas, where shortleaf and loblolly pine are common. Turkey oak dominates the understory in xeric sandhills sites east of the Mississippi River, but in the Big Thicket region of eastern Texas, bluejack and post oaks replace turkey oak (Christensen 1988; Stout and Marion 1993). Flatwoods have fewer oaks. Wiregrass dominates the understory in community occurrences east of eastern Mississippi. Other important grasses (and dominant grasses outside the range of wiregrass) are bluestems, muhlys (Muhlenbergia spp.), dropseeds (Sporobolus spp.), and toothache grass (Ctenium aromati cum) (Harcombe et al. 1993; Peet and Allard 1993).

The structure of natural sandhills communities is characterized by an open, sparse canopy of pine, an open understory dominated by scrubby oaks, and a herbaceous 
ground layer consisting of various grasses and forbs (Myers 1990). Pine flatwoods occur on extensiveflats or terraces and havelow, usually flat topography (Stout and Marion 1993). The soils are generally poorly drained sands with varying amounts of clay (Abrahamson and Hartnett 1990). Pine flatwoods typically have an emergent tree layer of pines with limbless lower trunks and a ground layer of low vegetation, but physiognomy varies markedly with fire regime and moisture (Stout and Marion 1993). The ecological quality of sites can be assessed using a combination of these compositional and structural attributes and, in turn, the quality of thecommunity can guide decisions regarding protection and management of the site.

\section{Fire and Hydrology}

High-quality longleaf pine woodland communities exist within a range of fire and hydrologic regimes. It is imperative to understand the fire and hydrol ogic processes that led to community devel opment and perpetuation in the past, and how land-use activities may or may not affect community quality due to alteration of these processes. Research suggests that frequent growing-season burning is the most influential management activity required to promote high-quality TES habitat in longleaf pine woodland areas. Accidental fires can be allowed to burn whenever feasible but, more often, managers will conduct prescribed burns. A fire-return interval of 1-3 years is recommended, but the fire return-interval on any given site should not be too regular. Similarly, growing season burns are recommended over winter burns, but each site should experience fire during different parts of the growing season to encourage a diverse ground cover and to minimize impacts to insects and amphibians. Since the ecosystem is compatible with a range of fire prescriptions, application of a prescribed burning program can beflexible, allowing for coordination with military training needs.

Planning efforts should consider several variables in addition to fire return interval and burn season. In areas with high fuel loads, different burning schedules and ignition techniques may be needed for several years. Variation in conditions through time and space will affect fire intensity and should be considered on a caseby-case basis. Fire intensity influences community composition and structure and also affects fire control considerations. Although widespread, frequent burning is beneficial to longleaf pine communities, managers must also account for the hazards of intense burns, smoke production and the adverse affects of fire control structures such as plowed fire lines. 
Plowed fire lines can contribute to altered water flow and soil erosion; alternatives may be moreappropriate in high-quality TES habitat. One of the best solutions can be to allow fire to burn through ecotones and into wetlands which also are fireadapted. Many rare plant species will benefit from such a policy (Harper et al. in prep). If it is necessary to prevent fire spread, existing trails and roads may be cleared or widened for use as control lines. Otherwise, fire can be controlled using spot fires, hand lines, chemical fire retardants, or (as a last resort), plowlines.

Altered hydrology from fire plowlines or other soil disruptions is most likely to impact (1) the quality of wet flatwoods, (2) the plants adapted to the ecotones between drier sandhills and wet communities, and (3) the fauna dependent upon flatwoods ponds. Wet pine flatwoods often have an organic or clay hardpan layer, which keeps rainwater from percolating into the deeper layers of soil. In the winter and early spring these areas are saturated, but they are dry during the growing season. Plant species adapted to these communities, or to the ecotones between these areas and adjacent woodlands, often have narrow tolerances to altered soilmoisture patterns. Hydrologic impacts may reduce or eliminate breeding habitat for gopher frogs and flatwoods salamanders by changing conditions in ephemeral flatwoods ponds or cypress wetlands. Altered hydrology may changethe vegetative characteristics of the environment, create permanent aquatic communities, or lead to early drying of the wetlands in the spring. In any case, breeding habitat for these TES species is reduced or eliminated. The following activities are most likely to cause significant hydrologic change in pine woodland communities: creation of fire plowlines or roadside ditches, off-road use by heavy vehicles, and fire suppression. Identification of necessary buffer zone distances for various topographic characteristics and various activities is still needed to promote management of wet communities as TES habitat, while minimizing restrictions on nearby incompatible activities.

\section{Soil and Groundcover}

In addition to fire and hydrologic processes, the quality of TES habitat depends on the integrity of the soil and groundcover. The sandy soils of many longleaf pine communities are susceptible to gully erosion, which changes hydrologic patterns and carries away nutrients. In soils containing a significant clay component, compaction may increase runoff velocities, and impede growth and survival of vegetative cover. Soil and vegetation are closely related. Most TES plants are associated with ground cover dominated by native species. TES, such as the flatwoods salamander and pine barrens treefrog, depend on certain vegetative characteristics for habitat. An intact, pyrogenic ground cover is essential for the 
spread of fire over large areas. While the ground cover is affected by fire and hydrologic regimes, and can be reduced through soil erosion or compaction, it also can be damaged from direct, physical disturbances, usually associated with mechanized-vehicle use in military training or forestry operations.

Early intervention is important for managing natural area soil resources. Although erosion cannot be prevented entirely, it can be harnessed before it damages valuable wetlands, lowlands, stream courses, TES habitat, or other high-quality sites. Two management rules may improve planning and implementation of an erosion management strategy:

1. Manage for quality wetlands, stream courses, ponds, and lakes. If wetlands and waterways are high-quality, the ecological status of uplands and terrestrial systems probably will be acceptable as well. This assumption is not meant to suggest that managers should not monitor terrestrial sites, but that wetlands and streams can serve as critical indicators for overall ecosystem status.

2. Correct erosion and sedimentation problems immediately. Repair damage before it becomes an obstacle to training or a threat to the integrity of TES habitat.

In high-quality TES habitat, it is best to prevent soil compaction, since mitigation measures will destroy native ground cover. It is advised that use of heavy equipment be limited to previously degraded areas and to soils with low potential for compaction because of high sand content. It is recommended to harden the core areas of frequently used bivouac and assembly sites with crushed rock. When portions of these areas require revegetation (i.e., if the edges begin to wash away), they can be ripped, disked, and replanted. Such intensive management should be used to prevent runoff or sedimentation into nearby high-quality areas or waterways.

To minimize impacts to native ground cover in high-quality TES habitat, activities such as pinestraw raking, forestry site preparation and harvest operations, and military training may be modified. For example, pinestraw raking schedules can minimize removal of live vegetation and allow for fuel build-up and prescribed burning between raking events. Intensive site preparation can be very damaging to native ground cover and TES plants. The least harmful technique is to use frequent prescribed burning to el iminatewoody shrubs and regeneratenative pines. Certain mechanical methods may be less harmful than others. For example, a single pass with a small drum chopper may kill oaks without removing the ground cover. Harvest strategies can account for sites' potential as TES habitat when 
determining how often to harvest and type of operation. For any given harvest operation, many methods are available to minimize soil and ground cover damage. Intensive military training is expected to cause the least damage when soils aredry and when conducted in drier flatwoods. However, frequent mechanized maneuver training most likely will result in such extensive and permanent alteration of the ground cover and fuel load that seasonal differences in soil moisture are probably insignificant compared to training intensity. Intensive training, including occupational exercises and assembly activities, generally destroy the ground cover much more quickly than it can recover. When this occurs, the repeated use of fewer "designated" sites, rather than rotation among many sites, will reduce the total area from which ground cover has been removed.

Most impacts research has documented potential effects on individual sites. In addition, the arrangement of TES habitat types on the entire installation may be important to survival and reproduction of listed species. Significant responses to habitat fragmentation have been documented for RCWs, gopher tortoises, Bachman's sparrows, and two snake species. The spatial arrangement of high-quality habitat will influence the ability of managers to maintain natural processes such as frequent fire events. One of the most powerful TES management strategies availableto DoD personnel is the creation of zones of land use priorities, taking into account the requirements of the military training and testing mission, the sitespecific impacts to TES populations, and the spatial relationship between different areas. A continuum of land uses can be permitted within zones of different priorities (after consultation with USFWS concerning TES habitat). One recommendation is to restore small zones of land that currently separate larger tracts of high-quality habitat, so species can move among the larger areas, and landscape processes such as fire can be maintained.

Managers may wish to restore longleaf pine woodland areas to increase available TES habitat or to support desired training objectives. Specific approaches have been developed to apply prescribed burning, sometimes in combination with mechanical or chemical midstory thinning techniques, to achieve the proper composition and physiognomic structure for these communities. Longleaf pine planting, midstory hardwood reduction, and restoration of native ground cover species are the major components of restoration efforts. 


\section{References}

Abrahamson, W.G., "Post-fire recovery of Florida LakeWales RidgeVegetation," American J ournal of Botany, Vol 71 (1984), pp 9-21.

Abrahamson, W.G., and D.C. Hartnett, "Pine flatwoods and dry prairies," in R.L. Myers and J J . Ewel (eds), Ecosystems of Florida (University of Central Florida Press, Orlando 1990).

Alabama Natural Heritage Program, Natural Heritagel nventory of F ort McClelan, Main Post: Federal Endangered, Threatened, CandidateSpecies and State-Listed Species, Alabama Natural Heritage Program (Alabama Department of Cons. and Nat. Res., State Lands Division, Montgomery, AL, 1994).

Allard, D.J ., Southeastern United States E cological Community Classification, Interim Report, Version 1.2 (TheN ature Conservancy, Southeast Regional Office, Chapel Hill, NC, 1990).

Allen, C.R., R.S. Lutz, and S. Demarais, "Red Imported Fire Ant I mpacts on Northern Bobwhite," Ecological Applications, Vol 5 (1995), pp 632-638.

Army Field Manual (AFM) 7-7, The Mechanized Infantry Platoon and Squad (APC) (Headquarters, Department of the Army [HQDA], March 1985).

AFM 5-100, Engineer Combat Operations (HQDA, November 1988).

AFM 71-100, Division Operations (HQDA, J une 1990).

Askew, G.R., and T.M. Williams, "Sediment Concentrations from Intensively Prepared Wetland Sites," Southern J ournal of Applied Forestry, Vol 8 (1984), pp 152-157.

Aust, W.M., T.W. Reisinger, J .A. Burger, and B.J . Stokes, "Soil Physical and Hydrological Changes Associated with Logging a Wet Pine Flat With Wide-tired Skidders," Southern J ournal of Applied Forestry, Vol 17 (1993), pp 22-25.

Aust, W.M., M.D. Tippett, J .A. Burger, and W.H. McKee, “Compaction and Rutting During Harvesting Affect Better Drained Soils More Than Poorly Drained Soils on Wet Pine Flats," Southern J ournal of Applied Forestry, Vol 19 (1995), pp 72-77. 
Beije, H.M., "Effects of Off-road Locomotion on Soil and Vegetation in Heathland," in Proceedings: NATO CCMS Seminar BlueB ook 159, Preservation of Flora and Fauna in Military Training Areas, ConferenceProceedings N-87/09/ADA179754(USACERL, 1987).

Beier, P., and S. Loe, "A Checklist for Evaluating I mpacts to Wildlife Movement Corridors," Wildlife Society Bulletin, Vol 20 (1992), pp 434-440.

Belanger, R.P., R.L. Hedden, and P.L. Lorio, "Management Strategies to Reduce Losses from the Southern PineB eetle," Southern J ournal of Appl i ed Forestry, Vol 17 (1993), pp 150-154.

Blackburn, W.H., J .C. Wood, H.A. Pearson, and R.W. Knight, "Storm Flow and Sediment Loss from Intensively Managed Forest Watersheds in East Texas," in Ecological, Physical, and Socioeconomic Relationships Within Southern National Forests, proceedings of the Southern Evaluation Project Workshop, 26-27 May 1987, General Tech Report SO-68, USDA FS, Southern F orest Experiment Station, New Orleans, LA, 1987.

Blakesley, J .A., and K.P. Reese, "Avian Use of Campground and Noncampground Sites in Riparian Zones," J ournal of Wildlife Management, Vol 52 (1988), pp 399-402.

Bohall, P.G., "Habitat Selection, Seasonal Abundance, and Foraging Ecology of American Kestrel Subspecies in North Florida," M.S. Thesis (Univ. Florida, Gainesville, FL, 1984).

Boyer, W.D., "Regenerating Longleaf Pine with Natural Seeding," S.M. Hermann (ed), Proceedings of the Tall Timbers Fire E cology Conference, No. 18, The Longleaf Pine Ecosystem: Ecology, Restoration and Management (Tall Timbers Research Station, Tallahassee, FL, 1993), pp 299-310.

Boyle, S.A., and F.B. Sampson, "Effects of Nonconsumptive Recreation on Wildlife: A Review," WildlifeSociety Bulletin, Vol 13 (1985), pp 110-116.

Bridges, E., Element Stewardship Abstract for Lauchnocaulon digynum (Bog buttons) (The Nature Conservancy, Southeastern Region, Chapel Hill, NC, 1986).

Bridges, E.L., and S.L. Orzell, "Longleaf PineCommunities of the West Gulf Coastal Plain," Natural Areas J ournal, Vol 9 (1989), pp 246-263.

Brown, R.B., E.L. Stone, and V.W. Carlisle, "Soils," in R.L. Myers and J .J . Ewel (eds), Ecosystems of Florida (University of Central Florida Press, Orlando, 1990). 
Burger, J .A., Physical impacts of harvesting and site preparation on soils, Proceedings of the Society of American Foresters, Appalachian section annual meeting (1983).

Canter, L.W., Final programmatic environmental impact statement, APHIS-ADM-81-01-F (USDA, Hyattsville, MD, 1981).

Christensen, N.L., "Fire Regimes in Southeastern Ecosystems," in H.A. Mooney, T.M. Bonnicker, N.L. Christensen, J .E. Loton, and W.A. Reinsers (eds), Fire Regimes and E cosystem Properties, General Tech. Rept. WO-26 (USDA F orest Service, 1981), pp 112-136.

Christensen, N.L., "Vegetation of the Southeastern Coastal Plain," in M.G. Barbour and W.D. Billings (eds), North American Terrestrial Vegetation (Cambridge University Press, New York, 1988).

Christman, S.P., Management of Florida Scrub at Camp Blanding, Clay County, Florida, draft report prepared for Camp Blanding Training Site, Camp Blanding, FL, 1995.

Clewell, A.F., "Natural History of Wiregrass (Aristida stricta Michx., Gramineae)," Natural Areas J ournal, Vol 9 (1989), pp 223-233.

Coile, N.C., and D.G. Shilling, "Cogon grass, I mperata cylindrica (L.) Beauv.: A Good Grass Gone Bad!" Botany Circular No. 28 (Florida Department Agric. \& Consumer Services, Division of Plant Industry, Gainesville, FL, 1993).

Cole, D.N., "Disturbance of Natural Vegetation by Camping: Experimental Applications of Low-level Stress," Environmental Management, Vol 19 (1995), pp 405-416.

Cole, D.N., "Research on Soil and Vegetation in Wilderness: A State-of-the-Knowledge Review," in R.C. Lucas, compiler, Proceedings of the National Wilderness Research Conference: I ssues, State-of-Knowl edge, Future Directions, Report INT-4901, USF S Intermountain Research Station, Ogden, UT, 1987.

Cole, D.N., and P.B. Landres, "I ndirect Effects of Recreation on Wildlife," in R.L. Knight and K.J. Gutzwiller (eds), Wildlife and Recreationists: Coexistence through Management and Research (I sland Press, Washington, DC., 1995).

Colvin, D.L., J . Gaffney, and D.G. Shilling, "Cogon Grass (I mperata cylindrica (L.) Beauv.) Biology, Ecology and Control in Florida," Circular SS-AGR-52, Weeds in the Sunshine Series (U niversity of Florida, Institute of Food and Agricultural Services, Gainesville, 1994). 
Conde, L.F., B.F. Swindel, and J .E. Smith, "Plant Species Cover, Frequency, and Biomass: Early Responses to Clearcutting, Chopping, and Bedding in Pinus el liottii Flatwoods," Forest Ecology and Management, Vol 6 (1983), pp 307-317.

Conner, R.N., and D.G. Rudol ph, "F orest Habitat Loss, Fragmentation, and Red-cockaded Woodpecker Populations," Wilson Bulletin, Vol 103 (1991), pp 446-457.

Currie, H., Natural Community Classification for Alabama (Alabama Department of Conservation and Natural Resources, Natural Heritage Program, Montgomery, AL, 1989).

Dale, D., and T. Weaver, "Trampling Effects on Vegetation of the Trail Corridors of North Rocky Mountain Forests," J ournal of Applied Ecology, Vol 11 (1974), pp 767-772.

Day, S.D., N.L. Bassuk, and H. vanEs, "Effects of Four Compaction Remediation Methods for Landscape Trees on Soil Aeration, Mechanical Impedance and Tree Establishment,"J ournal of Environmental Horticulture, Vol 13 (1995), pp 64-71.

Department of the Air Force, Natural Resources Management Plan, Eglin Air F orce Base, 1993-1997 (Eglin Air Force Base, FL, 1993).

Department of the Army (DA), Biological Assessment of Land-UseActivities on theK arner Blue Butterfly at Fort McCoy, WI, 1993.

DA, Final Environmental Impact Statement, Volume I, Military Training U se of National Forest Lands at Camp Shelby, Mississippi (Camp Shelby, MS, 1994).

DA, 1996 Management Guidel ines for theR ed-cockaded Woodpecker on Army I nstallations (Dept. of the Army, 30 October 1996).

Dickerson, B.P., Logging disturbance on erosive sites in northern Mississippi, Res. Note SO-72 (USDA Forest Service, 1968).

Dickerson, B.P., "Stormflows and Erosion After Tree-length Skidding on Coastal Plain Soils," Transactions of the ASAE, Vol 18 (1975), pp 867-869.

Diemer, J .E., "Gopherus polyphemus," in I.R. Swingland and M.W. Klemens (eds), The Conservation Biology of Tortoises, occasional papers (IUCN Species Survival Commission 5, 1989).

Dixon, W.N., E.L. Barnard, C.W. Fatzinger, and T. Miller, "Insect and Disease Management," in M.L. Duryea and P.M. Dougherty (eds), Forest Regeneration Manual (Kluwer Academic Publishers, Dordrecht, The Netherlands, 1991), pp 359-388. 
Dobrowolski, J .P., W.H. Blackburn, and H.E. Grelen, "Sediment Production for Long-term Burning of a Longleaf Pine- Bluestem Association," in Ecological, Physical, and Socioeconomic Relationships Within Southern National Forests, proceedings of the Southern Evaluation Project Workshop, 26-27 May 1987, General Tech Report SO-68 (USDA Southern Forest Experiment Station, New Orleans, LA, 1987).

Duever, L.C., "Research Priorities for the Preservation, Management, and Restoration of Wiregrass Ecosystems," Natural Areas J ournal, Vol 9 (1989), pp 214-218.

Dunning, J .B., "Bachman's sparrow," in A. Poole, P. Stettenheim, and F. Gill (eds), The Birds of N orth America, No. 38 (The Academy of Natural Sciences, Washington, DC, 1993).

Duvall, V.L., and N.E. Linnartz, "I nfluence of Grazing and Fire on Vegetation and Soils of the Longleaf Pine-Blue Stem Range," J ournal of Range Management, Vol 20 (1967), pp 241-246.

Echternacht, A.C., and L.D. Harris, "The F auna and Wildlife of the Southeastern U nited States," in W.H. Martin, S.G. Boiyce, and A.C. Echternacht (eds), Biodiversity of the Southeastern United States: Lowland Terrestrial Comunities (J ohn Wiley \& Sons, Inc, 1993), pp 81-116.

Eisenberg, J .F., "The Gopher Tortoise as a Keystone Species," in R.J . Bryant and R. Franz (eds), The Gopher Tortoise: a Keystone Species, Proceedings of the 4th Annual Meeting, Gopher Tortoise Council, Valdosta, GA, 1983.

Environmental Services \& Permitting, Inc., "Summary Endangered Species Survey at the J acksonville, Florida, Naval Complex," 1990.

Farrar, R.M., "Growth and Yield in Naturally Regenerated Longleaf Pine Stands," in S.M. Hermann (ed), Proceedings of theTall Timbers FireE cology Conference, No. 18, The Longleaf Pine Ecosystem: Ecology, Restoration and Management (Tall Timbers Research Station, Tallahassee, FL, 1993), pp 311-333.

Fisher, R.F., "I mpact of Intensive Silviculture on Soil and Water Quality in a Coastal Lowland," in R. Lal and E.W. Russell (eds), Tropical Agricultural Hydrology (J ohn Wiley and Sons Ltd, 1981).

Florida Exotic Plant Pest Council (EPPC), list of Florida's most invasive species, brochure (EPPC, Fort Lauderdale, FL, 1995).

Florida Natural Areas Inventory (FNAI) and Florida Department of Natural Resources (FDNR), Guide to the Natural Communities of Florida (FNAI and FDNR, Tallahassee, FL, 1990). 
FNAI, "Survey of Pensacola Naval Air Station and Outlying Field Bronson for Rare and Endangered Plants," Final Report to the Florida Game and Fresh Water Fish Commission, Contract No. W311, Tallahassee, FL, 1988.

FNAI, Biological Survey of the McCoy Annex/ Naval Training Center, Orlando, Florida (FNAl, Tallahassee, FL, 1992).

FNAI, Biological Survey of Tyndall Air F orce Base, Final Report (FNAI, Tallahassee, FL, 1994a).

FNAI, Eglin Natural Communities Survey: Year One Report (F NAI, Tallahassee, FL, 1994b).

FNAI and The Nature Conservancy (TNC), Camp Blanding Training Site Natural Community Survey, Final Report, Contract number ENV 1, 1995.

Frost, C., "Four Centuries of Changing Landscape Patterns in the Longleaf Pine Ecosystem," in S.M. Hermann (ed), Proceedings of the Tall Timbers Fire Ecology Conference, No. 18, The Longleaf Pine Ecosystem: Ecology, Restoration and Management (Tall Timbers Research Station, Tallahassee, FL, 1993), pp 17-44.

Frost, C.C., J. Walker, and R.K. Peet, "Fire-dependent Savannas and Prairies of the Southeast: Original Extent, Preservation Status and Management Problems,"in D.L. Kulhavy and R.N. Conner (eds), Wilderness and Natural Areas in theE astern United States: A Management Challenge (Center for Applied Studies, School of Forestry, Stephen F. Austin State University, Nacogdoches, TX, 1986).

Garton, E.O., B. Hall, and T.C. Foin, "The Impact of a Campground on the Bird Community of a Lodgepole Pine Forest," in T.C. Foin (ed), Visitor Impacts on National Parks: the Yosemite Ecological Impact Study, Institute of Ecology Publication No. 10 (University of California, Davis, CA, 1977).

Georgia Department of Natural Resources, "Summary Report, A Survey of Rare Species and Natural Communities at the Marine Corps Logistics Base, Albany, Georgia," Contract \#67004-90-M-0749 (Georgia Department of Natural Resources, Wildlife Resources Division, Georgia Natural Heritage Program, Social Circle, GA, 1994).

Gill, W.R. and R.D. Miller, "A Method for Study of the I nfluence of Mechanical I mpedance and Aeration on the Growth of Seedling Roots," Soil ScienceSociety Proceedings, Vol 20 (1956), pp 154-157.

Glitzenstein, J .S., D. Hardin, B. Means, K.W. Outcalt, J . Walker, and N. Wilkins, "Panel Discussion: Silviculture Effects on Groundcover Plant Communities in Longleaf Pine Forests," in S.M. Hermann (ed), Proceedings of the Tall Timbers Fire Ecology 
Conference, No. 18, The Longleaf Pine Ecosystem: Ecology, Restoration and Management (Tall Timbers Research Station, Tallahassee, FL, 1993), pp 357-370.

Glitzenstein, J S., D.R. Streng, and W. Platt, Evaluating the Effects of Season of Burn on Vegetation in Longleaf Pine Savannas, Final Draft Report to Florida Game and Freshwater Fish Commission, Nongame Wildlife Program, Tallahassee, FL, 1990.

Godfrey, R.K., and J .W. Wooten, Aquatic and Wetland Plants of the Southeastern United States, Monocotyledons (The University of Georgia Press, Athens, 1979).

Godfrey, R.K., and J .W. Wooten, Aquatic and Wetland Plants of the Southeastern United States, Dicotyledons (The University of Georgia Press, Athens, 1981).

Goran, W.D., L.L. Radke, and W.D. Severinghaus, An Overview of the Ecological Effects of Tracked Vehicles on Major U.S. Army Installations, TR N-142/ADA126694 (USACERL, 1983).

Gordon, D.R., and K.P. Thomas, Introduction Pathways for Invasive Non-indigenous Species, report by the Florida Department of Environmental Protection for the Florida state legislature.

Greacen, E.L., and R. Sands, "Compaction of Forest Soils, A Review," Australian J ournal of Soil Research, Vol 18 (1980), pp 163-89.

Greene, W.D., and W.B. Stuart, "Skidder and Tire Size Effects on Soil Compaction," Southern J ournal of Applied Forestry, Vol 9 (1985), pp 154-157.

Guertin, P., compiled notes and bibliographies on impacts of maneuver training and associated activities on plant, animal, and bird populations (USACERL, 1995).

Gulf Engineers \& Consultants, Inc., and Geo-Marine, Inc., Rare, Threatened and Endangered Species Survey and Their Habitat at Fort Benning, Georgia, Final Report, Contract No. DACW21-89-0016 (Baton Rouge, LA, 1994).

Hall, D.W., "Is It Wiregrass?" Natural Areas J ournal, Vol 9 (1989), pp 219-221.

Harcombe, P.A., J .S. Glitzenstein, R.G. Knox, S.L. Orzell, and E.L. Bridges, "Vegetation of the Longleaf Pine Region of the West Gulf Coastal Plain," in S.M. Hermann (ed), Proceedings of the Tall Timbers Fire E cology Conference, No. 18, The Longleaf Pine E cosystem: Ecology, Restoration and Management (Tall Timbers Research Station, Tallahassee, FL, 1993), pp 83-104. 
Hardin, E.D., and D.L. White, "Rare Vascular Plant Taxa Associated with Wiregrass (Aristida Stricta) in the Southeastern United States," Natural Areas J ournal, Vol 9 (1989), pp 234-245.

Harper, M., and A.M. Trame, Management of Herbaceous Seeps and Wet Savannas for Threatened and Endangered Species, draft technical report (USACERL, J anuary 1998).

Harris, L., The Fragmented Forest (University of Chicago Press, Chicago, IL, 1984).

Harrison, R.L., “Toward a Theory of I nter-refuge Corridor Design," Conservation Biol ogy, Vol 6 (1992), pp 293-295.

Hart, B.L., and G.D. Lester, Natural Community and SensitiveSpecies Assessment on F ort Polk Military Reservation, Louisiana, Contract/Purchase Order No. M67004-91-D0010, Final Report submitted to the Department of the Army Corps of Engineers, Memphis, TN (1993).

Harvey, C.A., and D. Pimentel, "Effects of Soil and Wood Depletion on Biodiversity," Biodiversity and Conservation, Vol 5 (1996), pp 1121-1130.

Hatchell, G.E., C.W. Ralston, and R.R. Foil, "Soil disturbances in logging: Effects on Soil Characteristics and Growth of Loblolly Pine in the Atlantic Coastal Plain," J ournal of F orestry, Vol 68 (1970), pp 772-775.

Haywood, J .D.,A. Martin, J r., and J .C. Novosad, "Responses of understory vegetation on highly erosive Louisiana soils to prescribed burning in May," Research N ote SO-383 (USDA Forest Service Southern Research Station, 1995).

H aywood, J .D., and R.E. Thill, "Long-term responses of understory vegetation on a highly erosive Louisiana soil to fertilization," Research Note SO-382 (USDA F orest Service Southern Research Station, 1995).

Heuberger, D., and J . Huffman, “Longleaf pine forest groundcover restoration," Resource Management Notes, Vol 4 (1992), pp 17-19.

H ooper, R.G., A.F . Robinson, and J .A.J ackson, Thered-cockaded woodpecker: notes on life history and management. Gen. Tech. SA-GR-9, (USDA Forest Serv, 1981).

Howie, S., Species of Concern on U.S. Air F orceLands: A BaseSpecific Handbook for Avon Park Air Force Range, Pilot Project, draft version (Department of the Air Force, 1994). 
Isley, D., Vascular Flora of the Southeastern United States (The University of North Carolina Press, 1990).

J ames, T.D.W., D.W. Smith, E.E. Mackintosh, M.K. Hoffman, and P. Monti, “Effects of Camping Recreation on Soil, J ack Pineand U nderstory Vegetation in a N orthwestern Ontario Park," Forest Science, Vol 25 (1979), pp 333-349.

J ohnson, A.F., Population Status Survey of Calamovilfa curtissii (Vasey) Lamson-Scribner (Florida Natural Areas Inventory, Tallahassee, FL, 1993a).

J ohnson, A.F., Population Status Survey of Polygonella macrophylla Small. (Florida Natural Areas I nventory, Tallahassee, FL, 1993b).

J ordan, R.A., Draft el ement stewardship abstract for Pituophis mel anoleucus (The Nature Conservancy, Southeastern Regional Office, Chapel Hill, NC,1995).

J ordan, R.A., K.S. Wheaton, and W.M. Weiher, Integrated Endangered Species Management Recommendations for Army Installations in the Southeastern United States: Assessment of Army-wide Management Guidelines for the Red-cockaded Woodpecker and Associated Endangered, Threatened and Candidate Species, final draft report prepared for the Natural Resources Division, USACERL (The Nature Conservancy, Southeast Regional Office, Chapel Hill, NC, 1995).

Kelly, L., Ph.D thesis, "Short-term Effects ofL ongleaf Pinestraw Raking on Plant Diversity and Community Dynamics in Croatan National Forest, N orth Carolina," PhD Thesis (North Carolina State U niversity, Raleigh, NC, 1996).

Kelly, L., and T.R. Wentworth, interim progress report for cooperative agreement no. 11148, submitted to the USDA F orest Service, Southern Research Station, Forest Soil Productivity in the Southeast, Research Work Unit (1993).

King, T., and S. Haines, Soil Compaction Absent in Plantation Thinning, Resource Note SO-251 (USDA F orest Service, 1979).

Kral, R., A Report on Some Rare, Threatened, or Endangered Forest-related Vascular Plants of the South, Tech. Pub. R8-TP2 (U.S. Department of Agriculture, Forest Service, Atlanta, GA, 1983).

Krusac, D.L., and J.M. Dabney, "Red-cockaded Woodpecker Recovery: An Ecological Approach to Managing Biological Diversity," Trans. 59th N. Amer. WildlifeNat. Res. Conf., Vol X (1994), pp 1-9.

Kuss, F.R., and A.R. Graefe, "E ffects of Recreation Trampling on Natural Area Vegetation," J ournal of Leisure Research, Vol 17 (1985), pp 165-183. 
Labat-Anderson, Inc., "Threatened and Endangered Species Survey, Hurlburt Field, Florida," Final Report (L-A Inc., Bellevue, FL, 1994).

Landers, J .L., J .A. Garner, and W.A. McRae, "Reproduction of Gopher Tortoises (Gopherus polyphemus) in Southwestern Georgia," Herpetologica, Vol 36 (1980), pp 353-361.

Langeland, K., Exotic Woody Plant Control, Circular 868 (Florida Cooperative Extension Service, Institute of F ood and Agricultural Sciences, University of Florida and Exotic Plant Pest Control Council, Gainesville, FL, 1990).

LeBlond, R.J ., J .O. Fussell, and A.L. Braswell, "I nventory of the Rare species, Natural Communities, and Critical Areas of the Camp Lejeune Marine Corps Base, North Carolina" (North Carolina Natural Heritage Program, DPR, Department Environment, Health, and Natural Resources, Raleigh, NC, 1994a).

LeBlond, R.J ., J .O. Fussell, and A.L. Braswell, "Inventory of the Rare Species, Natural Communities, and Critical Areas of the Great Sandy Run Area, Camp Lejeune Marine Corps Base, North Carolina" (North Carolina Natural Heritage Program, DPR, Department Environment, Health, and Natural Resources, Raleigh, NC, 1994b).

LeBlond, R.J ., J .O. Fussell, and A.L. Braswell, "Inventory of the Rare Species, Natural Communities, and Critical Areas of theCherry Point MarineCorps Air Station, N orth Carolina" (North Carolina Natural Heritage Program, DPR, Department Environment, Health, and Natural Resources, Raleigh, NC 1994c).

Lewis, C.E., G.W. Tanner, and W.S. Terry, "Plant Responses to Pine Management and Deferred-rotation Grazing in North Florida,"J ournal of Range Management, Vol 41 (1988), pp 460-465.

Lipscomb, D.J ., "I mpacts of Feral Hogs on L ongleaf PineRegeneration," Southern J ournal of Applied Forestry, Vol 13 (1989), pp 177-181.

Lockaby, B.G. and Vidrine, C.G., "E ffect of Logging Equipment and Traffic on Soil Density and Growth and Survival of Young Loblolly Pine," Southern J ournal of Applied Forestry, Vol 18 (1984), pp 109-112.

Lowery, R.F., and Gjerstad, D.H., "Chemical and Mechanical Site Preparation," in M.L. Duryea and P.M. Dougherty (eds), F orest Regeneration Manual (Kluwer Academic Publishers, Dordrecht, The Netherlands, 1991), pp 251-261.

Lull, H.W., "Soil Compaction on Forest Land," Forest Service Misc. Pub. 768 (USFS, Washington, DC, 1959). 
Marois, K.C., and K.C. Ewel, "Natural and Management-related Variation in Cypress Domes," Forestry Science, Vol 29 (1983), pp 627-640.

Martin, C.O., R.A. Fischer, M.G. Harper, D.J . Tazik, and A. Trame, Regional Strategies for Managing Threatened and Endangered Species Habitat: A Concept Plan and Status Report, Technical Report SERDP-96-1 (WES, 1996).

Martin, R.S., Community Characterization Abstract, Atlantic Coastal Plain Wet Longleaf Pine Savanna (TNC, Southeast Regional Office, Chapel Hill, NC, 1992a).

Martin, R.S., Community Characterization Abstract, Atlantic Coastal Plain Wet-Mesic Longleaf Pine Savanna (TNC, Southeast Regional Office, Chapel Hill, NC 1992b).

Martin, R.S., Community Characterization Abstract, East Gulf Coastal Plain Longleaf Pine Savanna (TNC, Southeast Regional Office, Chapel Hill, NC, 1992c).

Martin, R.S., Community Characterization Abstract, Slash Pine Flatwoods (TNC, Southeast Regional Office, Chapel Hill, NC, 1992d).

Martin, R.S., Community Characterization Abstract, Wet Longleaf Pine - Slash Pine Flatwoods (TNC, Southeast Regional Office, Chapel Hill, NC, 1992e).

McCoy, E.D., and H.R. Mushinsky, "Effects of Fragmentation on the Richness of Vertebrates in the Florida Scrub Habitat," E cology, Vol 75 (1994), pp 446-457.

McDonnell, M.J ., "Trampling Effects on Coastal Dune Vegetation in the Parker River National Wildlife Refuge, Massachusetts, USA," Biological Conservation, Vol 21 (1981), pp 289-301.

Mcl nnis, N.C., R.P. Martin, and J .A.Teague, Louisiana Army National Guard, Threatened and Endangered Species Natural Areas Survey, Camp Beauregard, final report (TNC, Baton Rouge, LA, 1995).

McMinn, J.W., and D.A. Crossley, J r. eds, "Biodiversity and Coarse Woody Debris in Southern F orests," Proceedings of theWorkshop on CoarseWoody Debris in Southern Forests: Effects on Biodiversity, General Technical Report SE-94 (USDA Forest Service Southern Research Station, 1993).

Means, D.B., and G. Grow, The Endangered Longleaf Pine Community, ENFO, Vol 85 (1985), pp 1-12.

Means, D.B., J .G. Palis, and M. Baggett, "Effects of Slash Pine Silviculture on Florida Panhandle Populations of the Flatwoods Salamander (Ambystoma cingulatum)," HL/SSAR J oint Annual Meeting abstract (University of Georgia, Athens, 1994). 
Menges, E.S., W.G. Abrahamson, K.T. Givens, N.P. Gallo, and J .N. Layne, "Twenty Years of Vegetation Change in Five Long-unburned Florida Plant Communities," J ournal of Vegetation Science, Vol 4 (1993), pp 375-386.

Michigan Department of Military Affairs (DMA), draft, Final Environmental Impact Statement of Mission Expansion/MultipleConstruction at Camp Grayling, Michigan, 1994.

Miller, J .H., and D.L. Sirois, "Soil Disturbance by SkylineY arding vs. Skidding in a Loamy Hill Forest," Soil Science American J .ournal, Vol 50 (1986), pp 1579-1583.

M oehring, D.M., and I.W. Rawls, "Detrimental Effects of Wet Weather Logging," J ournal of F orestry, Vol 68 (1970), pp 166-167.

Moler, P.E., "Eastern I ndigo Snake, Drymarchon corais couperi," in P.E. Moler (ed), Rare and Endangered Biota of Florida, Vol. III, Amphibians and Reptiles (Univ. Presses of Florida, Gainesville, 1992), pp 181-186.

Monk, C.D., "Successional and Environmental Relationships of the Forest Vegetation of North Central Florida," Amer. Midl. Nat., Vol 79 (1968), pp 441-457.

Moore, M.O., and D.E. Gianassi, "Sensitive Plant Species Survey: Fort Gordon Military Reservation," Report submitted to the USFWS by the Herbarium, University of Georgia, Athens, GA, 1992.

Moore, W.H., and B.F. Swindel, "Effects of site preparation on dry prairie vegetation in south Florida," Southern J ournal of Applied Forestry, Vol 5 (1981), pp 89-92.

Mount, R.H., and A.D. Diamond, Survey of theF auna and Flora of F ort Rucker, Alabama, Contract No. DABT01-01-C-0162 (1992).

Myers, R.L., "Scrub and High Pine," in R.L. Myers and J .J . E wel (eds), E cosystems of Florida (University of Central Florida Press, Orlando, FL, 1990), pp 150-193.

Myers, R.L., and J .J . Ewel, "Problems, Prospects, and Strategies for Conservation," in R.L. Myers and J .J . Ewel (eds), E cosystems of F Iorida (U niversity of Central Florida Press, Orlando, FL, 1990), pp 619-632.

Naval Air Station (NAS) Cecil Field, FL., The Fish and Wildlife section of the Natural Resource Management Plan, 1988.

NAS J acksonville, FL, The Fish and Wildlife section of the Natural Resource Management Plan, 1988. 
NAS Pensacola, FL, The Fish and Wildlife section of the Natural Resource Management Plan 1988.

NAS Whiting Field, FL, The Fish and Wildlife section of the Natural Resource Management Plan, 1991.

Naval Weapons Station, Charleston, SC, The Fish and Wildlife section of the Natural Resource Management Plan, 1989.

Nelson, J .B., The Natural Communities of South Carolina, Initial Classification and Description (South Carolina Wildlife and Marine Resources Dept., Columbia, SC, 1986).

Noss, R.F., "Corridors in Real Landscapes: a Reply to Simberloff and Cox," Conservation Biology, Vol 1 (1987), pp 159-164.

Noss, R.F., "The Longleaf Pine Landscape of the Southeast: Almost Gone and Almost Forgotten," Endangered Species Update, Vol 5 (1988) pp 1-8.

Noss, R.F., "Longleaf Pine and Wiregrass: Keystone Components of an Endangered E cosystem," Natural Areas J ournal, Vol 9 (1989), pp 211-213.

Noss, R.F., and L.D. Harris, "Node, Networks, and Mums: Preserving Diversity at All Scales," Environmental Management, Vol 10 (1986), pp 299-309.

Noss, R.F., E.T. LaRoe III, and J .M. Scott, Endangered Ecosystems of the United States: a Preliminary Assessment of Loss and Degradation (1992). Downloadable from the U.S. Geologic Survey, Biological Resources Division website: http://biology.usgs.gov/pubs/ ecosys.htm.

Nyland, R.D., et al., "Effects of Logging in Northern Hardwood Forests," TAPPI, Vol 60 (1977), pp 58-61.

Palis, J .G., Draft element stewardship abstract for Rana capito (The Nature Conservancy, Southeast Regional Office, Chapel Hill, NC, 1995).

Palis, J .G., "Element Stewardship Abstract for [Flatwoods Salamander] Ambystoma cingulatum," Natural Areas J ournal, Vol 16 (1996), pp 49-54.

Peet, R.K., "A Taxonomic Study of Aristida stricta and A. beyrichiana," Rhodora, Vol 95 (1993), pp 25-37.

Peet, R.K., and D.J . Allard, "Longleaf Pine Vegetation of the Southern Atlantic and Eastern Gulf Coast Regions: a Preliminary Classification," in S.M. Hermann (ed), 
Proceedings of the Tall Timbers Fire E cology Conference, No. 18, The Longleaf Pine E cosystem: Ecology, Restoration and Management (Tall Timbers Research Station, Tallahassee, FL, 1993), pp 45-82.

Penfound, W.T., and A.G. Watkins, "Phytosociological Studies of the Pinelands of Southeastern Louisiana," American Midland Naturalist, Vol 18 (1937), pp 661-682.

Platt, W.J ., J .S. Glitzenstein, and D.R. Streng, "Restoration and Management of Fireadapted Communities: An Experimental Study of Longleaf Pine Forests," Annual Report to the Florida Game and Fresh Water Fish Commission (Tallahassee, FL, 1989).

Platt, W., L. Smith, N. Gilmore, R. Baker, and D. Pashley, Proposed Management for Hillside Seepage Bogs of Kisatchie National Forest, draft report, 1990).

Provencher, L., G. Tanner, D. Gordon, and L. Brennan, “Cross-scale Analysis of Soil, Plant, Invertebrate, and Vertebrate Responses to Restoration Techniques in Degraded Florida Sandhill Systems," draft annual report to Natural Resources Division (Eglin AFB, 1995).

Provencher, L., D.R. Gordon, K.E.M. Galley, J .L. Hardesty, H.L. Rodgers, J . Sheehan, E. Levine, G.W. Tanner, L.A. Brennan, and K.W. Blandford, Prerestoration Analysis of Plants, Invertebrates, and Birds in Sandhill Systems at Eglin AFB, Florida, Annual Report to Natural Resources Division, Eglin AFB, FL, 1996.

Radford, A.E., H.E. Ahles, and C.R. Bell, Manual of the Vascular Flora of the Carolinas (The University of North Carolina Press, Chapel Hill, 1968).

Reed, P.B. J r., National List of Plant Species That Occur in Wetlands: Southeast (Region 2), Biol. Rept. 88(26.2), National Wetlands Inventory (USFWS, Washington, DC, 1988).

Reisinger, T.W., G.L. Simmons, and P.E. Pope, "The I mpact of Timber Harvesting on Soil Properties and Seedling Growth in the South," Southern J ournal of Applied Forestry, Vol 12 (1998), pp 58-67.

Robbins, L., and D. Hardin, Elemental stewardship abstract: Agrimonia incisa (Florida Field Office, The Nature Conservancy, 1987).

Robbins, L.E., and R.L. Myers, Seasonal Effects of Prescribed Burning in Florida: A Review, Miscellaneous Publication No. 8 (Tall Timbers Research, Inc., Tallahassee, $\mathrm{FL}$, 1992). 
Roberts, P.R., and H.J . Oosting, "Responses of Venus Fly Trap (Dionaea Muscipula) to Factors Involved in Its Endemism," Ecological Monographs, Vol 28 (1958), pp 193-218.

Robinson, A.F., "Possible Impacts of Silvicultural Activities on Proposed Endangered and Threatened Plant Species of PineFlatwoods," in W. E. Balmer (ed), Proceedings: Soil Moisture, Site Productivity Symposium, Myrtle Beach, SC., Nov. 1-3, 1977 (Department of Agriculture, Forest Service, Southeastern Area, State and Private Forestry, Atlanta, GA, 1978).

Roise, J . P., J Chung, and R. Lancia, "Red-cockaded Woodpecker Habitat Management and Longleaf Pine Straw Production: An Economic Analysis," Southern J ournal of Forestry, Vol 15 (1991), pp 88-92.

Rudolph, D.C., and R.N. Conner, "Red-cockaded Woodpeckers and Silvicultural Practice: Is Uneven-aged Silviculture Preferabl e to Even-aged?" WildlifeSociety Bulletin, Vol 24 (1996), pp 330-333.

Russo, M. J ., B.A. Sorrie, B. Van Eerden, and P.E. Hippensteel, Rare and Endangered Plant Survey and Natural Area I nventory for Fort Bragg and Camp Mackall Military Reservations, North Carolina (The Nature Conservancy, Carrboro, NC, and North Carolina Natural Heritage Program, 1993).

Schafale, M.P., E cological Concerns about Pine Straw Raking. A poster abstract in S.M. Hermann (ed), Proceedings of the Tall Timbers FireE col ogy Conference, No. 18, The Longl eaf PineE cosystem: E col ogy, Restoration and Management, p411 (Tall Timbers Research Station, Tallahassee, FL, 1993).

Schafale, M.P., and A.S. Weakley, "Ecological Concerns about Pine Straw Raking in Southeastern Longleaf Pine Ecosystems," North Carolina Heritage Program Newsletter (North Carolina Department of Environment, Health, and Natural Resources, Division of Parks and Recreation, 1990).

Schultz, R.P., Experimental Change after Site Preparation and Slash Pine Planting on a Flatwoods Site, Res. Pap. SE-156 (USDA Forest Service, Southeast. For. Exp. Stn., Asheville, NC, 1976).

Seamon, P.A., R.L. Myers, L.E. Robbins, and G.S. Seamon, "Stewards Circle: Wiregrass Reproduction and Community Restoration," Natural Areas J ournal, Vol 9 (1989), p 264.

Shea, M., "Status Survey Report on Platanthera integrilabia," Cooperative agreement no. 14-126-0004-89-956, work order no. 90-2 (Kentucky Endangered Plant Species Program, Kentucky State Nature Preserves Commission, Frankfort, KY, 1992). 
Simberl off, D., "Species-area and Fragmentation Effects on Old-growth F orests: Prospects for Longleaf Pine Communities," in S.M. Hermann (ed), Proceedings of the Tall Timbers Fire Ecology Conference, No. 18, The Longleaf Pine Ecosystem: Ecology, Restoration and Management (Tall Timbers Research Station, Tallahassee, FL, 1993), pp 1-13.

Simberloff, D., and J. Cox, "Consequences and Costs of Conservation Corridors," Conservation Biology, Vol 41 (1987), pp 18-25.

Small, J .K., Manual of the Southeastern Flora, Part Two (facsimile reprint of the 1933 edition) (Hafner Publishing Company, New York, 1972).

Smith, L.M., The Natural Communities of Louisiana (Louisiana Natural Heritage Program, Louisiana Department of Wildlife and Fisheries, Baton Rouge, LA, 1988).

Smith, I.K., draft element stewardship abstract for Balduina atropurpurea, (North Carolina Natural Heritage Program, Raleigh, NC, 1994).

Speake, D.W., J .A. McGlincy, and T.A. Colvin, "Ecology and Management of the Eastern Indigo Snake in Georgia: A Progress Report," in R.R. Odum and L. Landers, (eds), Proc. Rareand Endangered Wildlife Symp., Technical Bulletin WL4 (Georgia Dept. Nat. Res., Game and Fish Div. Tech., 1978), pp 64-73.

Stout, I.J ., and W.R. Marion, "Pine Flatwoods and Xeric Pine Forests of the Southern (Lower) Coastal Plain," in W.H. Martin, S.G. Boyce, and A.C. Echternacht (eds), Biodiversity of the Southeastern United States (J ohn Wiley \& Sons, Inc., N ew York, 1993), pp 373-446.

Strom, B.L., R.A. Goyer, and] .L. Hays, "Naturally Occurring Compound Can Protect Pines from the Southern Pine Beetle," Louisiana Agriculture, Vol 38 (1995), pp 5-7.

Swindel, B.F., L.F. Conde, and J .E. Smith, "Effects of Forest Regeneration Practices on Plant Diversity and Succession in Florida Ecosystems," Annual Symposium Proceedings on I mpacts of I ntensi veF orestry Management Practices, 14th ed. (School of Forest Resources and Conservation, University of Florida, Gainesville, 1982), pp 5-15.

Swindel, B.F.,W.R. Marion, L.D. Harris, L.A. Morris, W.L. Pritchett, L.F. Conde, H. Riekerk, and E.T. Sullivan, "Multi-resource Effects of Harvest, SitePreparation, and Planting in Pine Flatwoods," Southern J ournal of Applied Forestry, Vol 7 (1983), pp 6-15. 
Swindel, B.F., J .E. Smith, D.G. Neary, and N.B. Comerford, "Recent Research Indicates Plant Community Responses to Intensive Treatment Including Chemical Amendments," Southern J ournal of Applied Forestry, Vol 13 (1989), pp 152-156.

Taylor, H.M., and E. Burnett, "I nfluence of Soil Strength on the Root-growth Habits of Plants," Soil Science, Vol 98 (1964), pp 174-180.

Tazik, D.J ., J .D. Cornelius, D.M. Herbert, T.J . Hayden, and B.R. J ones, Biological Assessment of the E ffects of Military Associated Activities on Endanger ed Species at Fort Hood, Texas, Special Report EN-93/01/ADA263489 (USACERL, December 1992).

Teague, J .A., N.C. Mcl nnis, and R.P. Martin, Louisiana Army National Guard, Threatened and Endangered Species Natural Areas Survey, Camp Villerie, final report (TNC, Baton Rouge, LA, 1995).

Temple, S.W., and A.C. Mendel, "The Cow as a GeomorphologicAgent-A Critical Review," Geomorphology, Vol 13 (1995), pp 233-253.

TESII, Sarracenia leucophylla, whitetop pitcher plant, database compilation (USACERL, 1994).

The Nature Conservancy (TNC), Moody Air Force Base Natural Heritage I nventory, final report (Moody AFB, 1994).

TNC, Fort Stewart Inventory, Final Report (U.S. Department of Defense, Department of the Army, Headquarters 24th Mechanized Division, Fort Stewart, GA, 1995).

Thill, R.E., and J .C. Bellemore, Understory Responses to F ertilization of Eroded Kisatchie Soil in Louisiana, Research Note SO-330 (USDA F orest Service, 1986).

Thorud, D.B., and S.S. Frissell, J r., Time changes in soil density following compaction under an oak forest, Research Note257, Minn. Department of Forestry, St. Paul, MN, 1976.

Thurow, T.L., S.D. Warren, and D.H. Carlson, "Tracked Vehicle Effects on the Hydrologic Characteristics of Central Texas Rangeland," Transactions of theAmerican Society of Agricultural Engineers, Vol 36 (1993), pp 1645-1650.

Trame, A., and D.J . Tazik, Thel mplications of E cosystem Management for Threatened and Endangered Species Conservation by the U.S. Army, TR 95/27/ADA302406 (USACERL, September 1995). 
Trame, A., Known and Potential Impacts of Maneuver Training, Especially Physical Disturbance, on Threatened and Endangered Species, TR 97/70 (USACERL, April 1997).

Trame, A., and Mary Harper, Potential Military Effects on Selected Plant Communities in the Southeastern United States, TR 97/115/ADA329276 (USACERL, J uly 1997).

Trumbull, V.L., P.C. Dubois, R.J . Brozka, and R. Guyette, “Military Camping I mpacts on Vegetation and Soils of the Ozark Plateau,"J ournal of Environmental Management, Vol 40 (1994), pp 329-339.

U.S. Fish and Wildlife Service (USFWS), Eastern Indigo Snake Recovery PIan (USFWS, Atlanta, GA, 1982).

USFWS, Chapman's Rhododendron Recovery PIan (USFWS, Atlanta, GA, 1983).

USFWS, agency draft recovery plan for Rough-leaved loosestrife (Lysimachia asperulaefolia) (USFWS, Atlanta, GA, 1993a).

USFWS, Michaux's Sumac Recovery PIan (USFWS, Atlanta, GA, 1993b).

USFWS, Cool ey's Meadowrue Recovery PIan (USFWS, Atlanta, GA, 1994).

USFWS, draft recovery plan for 19 central Florida scrub and high pineland plants (revised) (USFWS, Atlanta, GA, 1995).

Vachta, E.G., and R.E. Riggins, Erosion Control Management Plan for Army Training Lands, TR N-90/11/ADA226558 (USACERL, 1990).

Vinson, S.B., and A.A. Sorenson, "I mported Fire Ants: Life History and Impact" (Texas Dept. of Agriculture, Austin, 1986).

Walker, J ., "Rare Vascular Plant Taxa Associated with the Longleaf Pine Ecosystems: Patterns in Taxonomy and E cology," in S.M. Hermann (ed), Proceedings of the Tall Timbers Fire Ecology Conference, No. 18, The Longleaf Pine E cosystem: Ecology, Restoration, and Management (Tall Timbers Research Station, Tallahassee, FL, 1993), pp 105-126.

Walker, J ., and R.K. Peet, "Composition and Species Diversity of Pine-wiregrass Savannas of the Green Swamp, North Carolina," Vegetation, Vol 55 (1983), pp 163-179.

Wallace, J .B., J .W. Grubaugh, and M.R. Whiles, "I nfluences of Coarse Woody Debris on Stream Habitats and I nvertebrate Biodiversity," in J .W. McMinn and D.A. Crossley J r. (eds), Biodiversity and Coarse Woody Debris in Southern Forests, Proceedings of 
the Workshop on Coarse Woody Debris in Southern Forests: Effect on Biodiversity, General Technical Report SE-94 (USDA F orest Service Southern Research Station, 1993), pp 119-129.

Ward, D.B., Rareand Endangered Biota of Florida, VolumeFive, Plants (University Press of Florida, Gainesville, 1979).

Ware, S.W., C. Frost, and P.D. Doerr, "Southern Mixed Hardwood Forest: The Former Longleaf Pine Forest," in W.H. Martin, S.G. Boyce, and A.C. Echternacht (eds), Biodiversity of theSoutheastern United States (J ohn Wiley \& Sons, Inc., New York, 1993), pp 447-494.

Watson, G.E., "Influence of Fire on the Longleaf Pine-bluestem Range in the Big Thicket Region," in D.L. Kulhavy and R.N. Conner (eds), Wilderness and Natural Areas in the Eastern United States: A Management Challenge (Center for Applied Studies, School of Forestry, Stephen F. Austin State U niversity, Nacogdoches, TX, 1986).

Wharton, C.H., The Natural Environments of Georgia (Geologic and Water Resources Division and Resource Planning Section, Office of Planning and Research, Georgia Department of Natural Resources, Atlanta, GA, 1978).

Whitworth, W.R., and A. Hill, Applicability of Land Condition Trend Analysis Data for Biological Diversity Assessment in theSoutheastern United States, Technical Report 97/67/ADA327477 (USACERL, 1997).

Wood, J .C., W.H. Blackburn, H.A. Pearson, T.K. Hunter, and R.W. Knight, "Assessment of Silvicultural and Grazing Treatment Impacts on Infiltration and Runoff Water Quality of Longleaf Slash Pine Forest, Kisatchie National Forest, Louisiana," in Ecological, Physical, and Socioeconomic Relationships Within Southern National Forests, proceedings of theSouthern Evaluation Project Workshop, 26-27 May 1987, General Tech Report SO-68 (USDAFS Southern Forest Experiment Station, New Orleans, LA, 1987).

Yoho, N.S., "Forest management and sediment production in the south: a review," Southern J ournal of Applied Forestry, Vol 4 (1980), pp 27-36.

Zappalorti, R.T., Herpetological Associates, Forked River, NJ (pers. comm. with R. J ordan, TNC-SERO, Chapel Hill, NC, 1994).

\section{Personal Communications}

Ballard, Louis, 1994, Personal communication between M. Harper and Louis Ballard, Fire Management Officer, Natural Resources, J ackson Guard, Niceville, FL. 
Beaty, Tim, 1994, Personal communication between M. Harper and Tim Beaty, Wildlife Biologist, F ort Stewart, GA.

Bebb, Scott, 1995, Personal communication between M. Harper and S. Bebb, Chief, Endangered Species Branch, Fort Bragg, NC.

Braswell, Alvin, 1996, Personal communication between R. Fischer and A. Braswell, Biologist, North Carolina State Museum of Natural Sciences.

Brozka, Robert, 1994, Personal Communication between M. Harper and R. Brozka, Assistant Director, Field Operations, Center for Ecological Management of Military Lands (CEMML), Colorado State University, F ort Collins, CO.

Coile, Dr. Nancy, 1996, Personal communication between A. Trame and Dr. Nancy Coile, Botany Administrator, Division of Plant I ndustry, Florida Department of Agriculture and Consumer Services.

Hamilton, Steve, 1995, Personal communication between M. Harper and Steve Hamilton, Research Fishery Biologist, National Biological Service, Midwest Science Center, Field Research Station, Rural Route 1, Box 295, Yankton, SD 57078-9214, (605) 6659217.

Hansard, R., 1995, Personal communication between A. Trame and R. Hansard, Plant Materials Specialist, N orth Carolina Natural Resouce Conservation Service (NRCS).

H offman, Eri, 1996, Personal communication between M. Harper and E. Hoffman, Wildlife Biologist, Endangered Species Branch, Fort Bragg, NC.

J ackson, J erry, 1995, Personal communication between M. Harper and J. J ackson, Professor, Mississippi State University.

J ohnson, J ., 1995, Personal communication between A. Trame and J . J ohnson, Forester, Alabama NRCS.

J ubinsky, Greg, 1995, Personal communication between M. Harper and Greg J ubinsky, Administrator, Bureau of Aquatic Plant Management, Florida Department of Environmental Protection Studies.

Kelly, Lisa, 1995 and 1996, Personal communications between M. Harper and Lisa Kelly, Graduate Student, Department of Botany, North Carolina State University.

Lane, David, 1995, Personal communication between A. Trame and David Lane, Manager, J amie L. Whitten Plant Materials Center, Mississippi NRCS. 
Larson, Diane, 1995, Personal communication between Mary G. Harper and DianeL arson, Research Biologist, National Biological Service, Northern Prairie Science Center, 8711 37th St. SE , J amestown, North Dakota 58401-7317, (701)252-5363.

MacRoberts, Michael, 1995, Personal communication between A. Trame and Michael MacRoberts, Botanist and Consultant, Bog Research, Shreveport, LA.

Martin, David, 1995, Personal communication between Mary G. Harper and David Martin, Botanist, USFWS.

Murian, J ames, 1995, Personal communication between Mary G. Harper and J ames Murian, Assistant Director for Stewardship, The Nature Conservancy, 222 South Westmonte Drive, Suite 300, Altimonte Springs, FL, 32714, (407) 682-3664.

Palis, J ohn G., 1996, review comments on a draft report sent to A. Trame from J ohn Palis, Ecologist, The Nature Conservancy.

Parris, Steve, 1995, Personal communication between A.Trame, R. Fischer and Steve Parris, Ecologist, Fort Polk, LA.

Pittman, Bert, 1995, List of plant communities known to occur on Fort J ackson, SC, given to Mary G. Harper from Bert Pittman, Community Ecologist, South Carolina State Natural Heritage Program, Columbia, SC.

Proffitt, J oe, 1996, Personal communication between A. Trame and J oe Proffitt, LCTA Coordinator, Fort Pickett, VA.

Provencher, Louis, 1995, Personal communication between Mary Harper and Louis Provencher, Research E cologist (TNC), principal investigator for study done at Eglin AFB entitled "Cross-scale analysis of soil, plant, invertebrate, and vertebrate responses to restoration techniques in degraded Florida sandhill systems."

Reilly, Steve, 1996, Personal communication between M. Harper and Steve Reilly, Senior Forestry Technician, Fort Bragg, NC.

Robertson, Kevin, 1996, Personal communication between M. Harper and Kevin Robertson, Short Form Research Contractor, USACERL, Champaign, IL.

Schafale, Michael, 1994, Lists of rare species and natural communities known to occur on the Sunnypoint Military Ocean Terminal, North Carolina sent to Mary G. Harper from Michael Schafale, Community E col ogist, N orth Carol ina StateN atural Heritage Program, Raleigh, NC. 
Segar, J., 1996, Personal communication between Kevin Robertson and J. Segar, Prescribed Fire Specialist, Long Pine Key Fire Cache, Everglades National Park, FL.

Shipley, J anet, 1995, 1996, Personal communication between M. Harper, A. Trame, and J anet Shipley, Endangered Species Botanist, Fort Bragg, NC.

Smith, L., 1997, Personal communication between A-M. Trame and L. Smith, Community Ecologist, Louisiana Natural Heritage Program.

Stanton, Robert, 1995, Personal communication between M. Harper and Robert Stanton, Fire Consultant, Prescribed Fire Consulting, 3605 Spring Road, Oakbrook, IL 60521, (708) 323-6359.

Stewart, Rhonda, 1995, Personal communications between M. Harper, A. Trame, and Rhonda Stewart, Botanist/E cologist, Kisatchie National Forest, LA.

Tanner, G., 1996, Comments on draft of Southern Pine Woodlands document, Associate Professor, University of Florida, Gainesville.

U.S. Forest Service representative, 1995, Personal communication between A. Trame and anonymous USFS representative from the Kisatchie National Forest, LA.

Weakley, Alan, 1995, Personal Communication between M. Harper, A. Trame, and Alan Weakley, Southeast Regional Ecologist, Southeast Regional Office, The Nature Conservancy.

Wieland, Ronald, 1994, Managed Area Basic Records for Camp Shel by and NAS Meridian, sent to Mary G. Harper on 2 November 1994 from Ronald Wieland at the Mississippi Department of Wildlife, Fisheries and Parks, J ackson, MS.

Williamson, J erry, 1995, Personal communication between A. Trameand J erry Williamson, NRCS Range Soil Conservationist on Interpersonnel Agreement with Army Environmental Center, MD. 


\section{Appendix A: An Ecological Description of the Sandhills Community}

\section{Nomenclature}

A. System: Terrestrial (Allard 1990)

B. Physiognomic Type: Terrestrial woodlands

\section{Classification System}

This community refers to "Iongleaf pine-turkey oak (Pinus palustris - Quercus laevis) sandhills" of Stout and Marion (1993), "sandhill pineforests" of Christensen (1988), and "high-pine" of Myers (1990). Additional synonyms for this community are: sandhill country, xerophyticdeciduous forest, xerophytic coniferous forest, pineturkey oak sandridge, fall-line sandhill, Florida sandhill association, clayridge forest, dwarf oak forest, evergreen shrub forest, turkey oak barrens, scrub oak barrens, and sandhill pine forest (reviewed in Stout and Marion 1993).

Several longleaf pine-turkey oak sandhill communities are described under a variety of names in state classification systems. In Louisiana, there are several types of upland longleaf pine forests and sandy woodlands (Smith 1988). In Georgia, this community is called clayridge forest and dwarf oak forest (Wharton 1978). Nelson's (1986) xeric sandhill scrub and pine-scrub oak sandhill communities in South Carolina are types of this community, as are sandhills in Alabama (Currie 1989), pine-scrub oak sandhills, xeric sandhill scrubs, and coastal fringe sandhills in North Carolina (Schafaleand Weakley 1990), and sandhills and upland pine forests in Florida (FNAI and FDNR 1990). In Virginia, the longleaf pine-turkey oak sandhill community is a type of oligotrophic or submesotrophic woodland (Allard 1990). In Texas, this community is part of the bluejack oak (Quercus incana) - pine series (Allard 1990). 


\section{Range}

A. Bailey's Ecoregion: Province 232-Outer Coastal Plain Mixed Forest Province.

B. Current Distribution: Eastern Virginia south to Martin County, FL, and west al ong the outer coastal plain to the Big Thicket region of Texas. Interior stands occupy the fall line in Alabama, Georgia, North Carolina, and South Carolina (Stout and Marion 1993).

\section{Environmental Factors}

A. Topographic Position: This community occurs in areas with rolling topography (Stout and Marion 1993). It occupies ridge tops, sand rims of Carolina bays, and relict dune ridges of lower coastal terraces (Christensen 1988). It also occurs on ridges of the fall-line sandhills, on the Southern Lake Wales Ridge of south central Florida, and on river terraces with deep sandy soils in the Big Thicket region in southeast Texas (Stout and Marion 1993).

B. Hydrology: The community generally occurs on well-drained, dry to xeric soils (Myers 1990).

C. Fire Regime: The natural fire return interval is believed to be every 1 to 3 years (Stout and Marion 1993). Compared to subxeric sandhills, the most xeric habitats may burn less frequently due to having a slower build-up of fuel. Frequent, lowintensity surface fires maintain this community (Christensen 1988).

D. Soil F eatures: This community occurs on both sandhills and clayhills. Sandhill soils are acidic, overly drained, highly permeable, low in nutrients, and are dassified as entisols. In contrast, clayhill soils are characterized by clayey subsoil overlain by sand or clayey sand, and are classified as ultisols. Clayhill soils are well-drained. The clayey subsoil holds water that is available to plants. Fertility of clayhill soils ranges from good to moderate (Myers 1990).

\footnotetext{
The fall line marks the separation between the Piedmont and Coastal Plain physiographic regions in the Southeastern United States.
} 


\section{Physiognomy/Structure}

Community structure is characterized by an open, sparse canopy of pine, an open understory dominated by scrubby oaks (which are often stunted and gnarled) and a herbaceous ground layer consisting of various grasses and forbs (Myers 1990). Physiognomy varies with moisture, fire regime, and geographic location (see Variation in Structure and Composition, $\mathrm{p}$ 128).

\section{Commonly Associated Plant Communities}

This community may grade into pine flatwoods, sand pine (Pinus clausa ) scrub, mesic hardwood forest, xerichammock (Abrahamson and Hartnett 1990) or a mixed oak-pine community (H arcombeet al. 1993). The soil, topographic, and disturbance factors that explain differences between this mixed oak-pine community and the longleaf pine community are not yet clear (Harcombe et al. 1993). Small, often isolated, examples of communities that may occur as inclusions in longleaf pine sandhills are sandstone outcrops (Smith 1988), sandhill seeps, small depression pocosin and ponds, and vernal pools (Schafale and Weakley 1990).

\section{Successional Relationships}

Reduced fire frequency may lead to an increase in stature of understory woody vegetation and a decrease in ground vegetation, followed by succession to a xeric hardwood/mixed pine community (Stout and Marion 1993). As a result of fire suppression over 40 years, the community may be invaded by scrub, mesic species, and sand pine as in Florida (Stout and Marion 1993). Invasion by these species may alter the fire regime from one characterized by short-interval, cool ground fires to one characterized by long-interval crown killing fires, which would maintain the community as a sand pine scrub community (Christensen 1988). Long-term fire suppression may lead to the development of a xeric hardwood forest (Christensen 1988; Stout and Marion 1993).

\section{Biological Composition}

A. Dominant Plant Species: Longleaf pine dominates the canopy except in southeast and south central Florida stands, which may consist of slash pine (Pinus eliottii) or a mixture of the two. In eastern Texas, Iongleaf pine, shortleaf pine 
(Pinus echinata), and loblolly pine (Pinus taeda) are codominants. Turkey oak dominates the understory in community occurrences east of the Mississippi River. Coastal fringe examples of this community have significant abundances of both sand live oak (Quercus geminata) and sand laurel oak (Q. hemisphaerica). Sandier inland sites will often includebluejack (Quercus incana) and sand post oak (Quercus margarettae) in addition to turkey oak. Post oak and blackjack oak are found on hills with more clay content. Persimmon is a very common understory species throughout the region east of the Mississippi River (Peet and Allard 1993). In the coastal plain west of the Mississippi, including the Big Thicket region of southeastern Texas, bluejack oak, sand post oak, and hickories (Carya spp.) replace turkey oak as understory dominants (Harcombe et al. 1993; Christensen 1988; Stout and Marion 1993). In Florida, wiregrass (Aristida stricta or A. beytrichiana) dominates the understory in community occurrences east of Escambia County. A transition in understory species dominance occurs in Escambia County with little bluestem and other bluestem grass dominating from there to east Texas (Myers 1990). On the western coastal plain, the drier longleaf pine woodlands have a sparse herbaceous layer, abundant lichens, and exposed sand. The important grasses include bluestems, dropseeds, and low panicums (Bridges and Orzell 1989).

B. Variation in Structureand Composition: Community composition and structure vary with fire frequency, soil, and geographic location. Christensen (1988) divided this community into three associations for the majority of the region east of the Mississippi River:

The association of pine-turkey oak sandridge forest occurs in the most xeric environments. Tree density is low (50/ha) and trees are stunted and gnarled. Turkey oak dominates the understory, and black gum (Nyssa sylvatica var. sylvatica) and persimmon (Di ospyros virgi niana) may occur as scattered individuals. The low shrubs, staggerbush (Lyonia mariana), and dwarf huckleberry form small clumps (2 percent cover). In addition, foliose lichens (Cladonia spp., Cladina spp.) and sand-binding lichen (Lecidea uliginosa) form a low mat. Broom moss (Dicramum spurium) dominates the ground under the oaks. Common and indicative herb species are sandwort (Arenaria caroliniana), tread softly (Cnidoscolus stimulosus), sand spikemoss (Selaginella arenicola), and wireplant (Stipulicida setacea; reviewed in Christensen 1988).

In the fall line sandhill association, ridgetops are dominated by turkey oak. Downslope, and with increasing day content in the soil, blackjack oak, sandhill post oak, and bluejack oak share understory dominance. Other understory trees include blackgum, persimmon, and sweetgum (Liquidambar styraciflua). Theground cover is dominated by wiregrass, and also includes dwarf huckleberry and blueberry 
(Vaccinium spp.). In areas where vascular plant growth is sparse, mosses and lichens are abundant. Bracken fern (Pteridium aquilinum) becomes abundant in areas where the clay horizon is near the surface and moisture is abundant (reviewed in Christensen 1988).

In the Florida sandhill association, Monk (1968) recognized three phases: (1) driest sites were dominated by turkey oak, (2) finer textured, more fertile soils supported bluejack oak, and (3) calcareous soils were dominated by southern red oak. Longleaf pine may dominate the canopy or codominate with slash pine. The turkey oak phase is structurally similar to the pine-turkey oak sandridge association al ready described. The herb layer is dominated by wiregrass and slender dropseed (Sporobol us gracilis). Gopher apple (Chrysobal anus oblongifol ius) is the dominant shrub, although it is also scarce. In the bluejack oak phase, live oak (Quercus virginiana) is a common canopy tree, and wiregrass forms a dense groundcover. The southern red oak phase grades into southern mixed hardwood forest (reviewed in Christensen 1988).

A second Florida sandhill association is the southern ridge sandhill community, which occurs in the southeast Lake Wales Ridge and is dominated by slash pine, or a mixture of slash and longleaf pines. Two understory phases are recognized: (1) turkey oak on well-drained sites and (2) scrub hickory (Carya floridana) at lower elevations on less well-drained sites (reviewed in Christensen 1988).

In the Big Thicket region of eastern Texas and in Louisiana, the canopy can be codominated by longleaf, shortleaf, and loblolly pines if fire is infrequent. The understory is codominated by bluejack and post oaks. Yaupon (I lex vomitoria) and flowering dogwood also are common in the understory.

Exploitation of longleaf pine may have led to development of a community dominated by pines and oaks, rather than just pines. Historical accounts suggest that in precolonial times, ridges were dominated by longleaf pine, exhibited a relatively open understory, and experienced frequent fire. Pine extraction allowed turkey oak and persimmon to increase in dominance (reviewed in Stout and Marion 1993). Short-term fire suppression may lead to an increase in stature and abundance of understory trees and a decrease in abundance and richness of the ground cover (Stout and Marion 1993; see Successional Relationships, p 127). 


\title{
Appendix B: An Ecological Description of the Pine Flatwoods Community
}

\author{
Nomenclature
}

A. System: Terrestrial or Palustrine (Allard 1990)

B. Physiognomic Type: Terrestrial Woodland/Savannas and Palustrine Woodland/Savannas (Allard 1990)

\section{Classification System}

This community is synonymous with the "flatwoods" community described by Stout and Marion (1993), the "mesic pine communities," (including flatwoods and savannas) of Christensen (1988), and the "flatwoods" of Abrahamson and Hartnett (1990). Also included in this description are "wetland longleaf pinesavannas" of the West Gulf Coastal Plain, described in Bridges and Orzell (1989).

Several pine flatwoods communities are described under a variety of names in state dassification systems. In Louisiana, pineflatwoods and pinesavannas are referred to as mesic pine flatwoods and wet pinewood savannas respectively (Smith 1988). Wharton's (1978) mesic pine lowland forest and longleaf pine upland forest in Georgia are also types of pine flatwoods (Stout and Marion 1993). In Mississippi, coastal flatwood forests, wet flatwood forests, wet pine savannas, and pine savannas are types of pine flatwoods (Allard 1990). Nelson's (1986) pinesavannas, pine flatwoods, pine-saw palmetto (Serenoa repens) flatwoods, and upland pinewiregrass (Aristida stricta or A. beyrichiana) woodlands in South Carolina are all types of pine flatwoods communities. In North Carolina's state classification (Schafale and Weakley 1990), wet pine flatwoods, pine savannas, and mesic pine flatwoods are all types of pine flatwoods, as are mesic flatwoods and wet flatwoods in Florida (FNAI and FDNR 1990). In Texas, the longleaf pine-beakrush series is a pine flatwoods community (Allard 1990). 


\section{Range}

A. Bailey's Ecoregion: Province 232-Outer Coastal Plain Mixed Forest. Section 232B-Coastal Plains and Flatwoods, Lower; Section 232C-Atlantic Coastal Flatlands; Section 232D-F lorida Coastal Lowlands (Western); Section 232F -Coastal Plains and Flatwoods, Western Gulf; 232G-Florida Coastal Lowlands (Eastern).

B. Current Distribution: Southeastern coastal plain from Southeast Virginia south to Florida and west to Texas (Stout and Marion 1993).

\section{Environmental Factors}

A. Topographic Position: This community occurs on extensive flats or terraces and generally has low, flat topography (Stout and Marion 1993). On the West Gulf Coastal Plain, abundant pimple mounds and swales provide microtopographic heterogeneity (Bridges and Orzell 1989).

B. Hydrology: The community occurs on poorly drained soils. Soils may be saturated or exhibit standing water during the wet season, but may also dry out during the summer (Christensen 1988).

C. Fire Regime: Frequent, low-intensity surface fires generally characterize the fire regime. Historical evidence suggested that a fire frequency of 1 to 3 years is necessary to maintain this community (Ware, Frost, and Doerr 1993). The chances that a severe, crown-killing fire will occur increase as the fire frequency decreases (Christensen 1988).

D. Soil: This community occurs on fine sandy loams, silt loams, and sandy soils that are poorly drained, acidic, and otherwise low in nutrients (Abrahamson and Hartnett 1990). Moisture level, pH, texture, and clay content of the soil vary across the range of this community. Soils supporting this community in the West Gulf Coastal Plain are generally more calcareous than those to the east (Bridges and Orzell 1989).

\section{Physiognomy/Structure}

Pine flatwoods (sensu Stout and Marion 1993) typically exhibit an emergent tree layer of pines with limbless lower trunks and a ground layer of low vegetation. 
However, physiognomy varies markedly with fire regime and moisture. For this reason, some authors (e.g., Christensen 1988) have subdivided pine flatwoods into two communities, flatwoods and savannas. In this case, "savannas" generally refer to communities that have not experienced fire suppression and have a sparse canopy of pines and a diverse groundcover, while "flatwoods" may refer to firesuppressed communities that exhibit a well-developed woody understory and a sparsegroundcover (Christensen 1988). N ote that, in other cases (e.g., Schafaleand Weakley 1990), flatwoods and savannas refer to communities on different physical sites.

\section{Commonly Associated Plant Communities}

Wet prairies, marshes, upland sandhills, pinewoods, dry prairies, sand pine (Pinus dausa) scrub, scrubby flatwoods, xeric sandhills, and pocosins often occur adjacent to pine flatwoods (Abrahamson and Hartnett 1990, Christensen 1988). Pine flatwoods can be bordered by beech-magnolia (Fagus grandifolia - Magnolia grandiflora) forest (southern mixed hardwood forest) on slopes (Bridges and Orzell 1989). In southwest Louisiana and southeast Texas, this community can grade directly into coastal prairie to the south (Bridges and Orzell 1989). Smaller, often isolated examples of communities that may be inclusions in pine flatwoods are pocosins (cypress [Taxodium spp.] dome and swamp forests, pond cypress [T. ascendens] pond forests, and small depression pocosins), pitcher plant (Sarracenia spp.) communities, and Coastal Plain small depression pond complexes (Martin 1992a-e).

\section{Successional Relationships}

Typical pine flatwoods may succeed to southern mixed hardwoods in the absence of fire, but successional rates and final composition of the vegetation may vary according to site conditions (Christensen 1988). Wetter slash pine and pond pine phases of pine flatwoods may succeed into bayheads (see Menges et. al. 1993 for results of a 20-yr study; Stout and Marion 1993). In North Carolina, flatwoods often either succeed to pocosins or persist with low species richness, in the absence of fire (M. Schafale, pers. comm., 1994). 


\section{Biological Composition}

A. Dominant or Characteristic Plant Species: Longleaf pine, slash pine, and pond pine usually dominate the canopy in pure stands or in various combinations. In Louisiana, loblolly or shortleaf pinemay beimportant canopy species (Smith 1988). Common understory species are gall berry, shiny blueberry, fetterbush, dwarf live oak, runner oak, sand live oak, hairy laurel, and southern bayberry (Myrica cerifera). Saw palmetto may also be a dominant understory component within its range (Stout and Marion 1993). Predictable grasses are wiregrass or bluestems (Andropogon and Schizachyrium spp.). Other grasses that may be important are muhly's (Muhlenbergi a spp.), dropseeds (Sporobol usspp.), and toothachegrass (Peet and Allard 1993, Harcombe et al. 1993). Common forbs are milkweeds (Asclepias spp.), pinebarren aster (Aster reticulatus), vanillaleaf (Carphephorus odoratissimus), gayfeather (Liatris spp.), queens delight (Stillingia sylvatica), baptisia (Baptisia spp.), milkpea (Galactia spp.), yellow colicroot (Aletris lutea), deathcamas (Zigadenus spp.), polygala (Polygala spp.), and yellow-eyed grasses (Xyris spp.; Stout and Marion 1993).

B. Variation in Structure and Composition: The composition and structure of pine flatwoods vary with geographiclocation, soil conditions, climate, and firefrequency. Historically, longleaf pine dominated more upland sites, while slash pine and pond pine increased in dominance with increasing periods of wetness and decreasing fire frequency. Slash pine would be codominant in its range west of southeastern Louisiana, and north of Georgetown Co., SC, while pond pine was sometimes codominant up to eastern North Carolina. Otherwise, longleaf pine occurred as a single dominant. Wiregrass is characteristic in pine flatwoods east of Mississippi, but bluestems, muhlys, and toothache grass are characteristic in pine flatwoods to the west (Stout and Marion 1993).

East of the Mississippi River, five distinct understory phases in pine flatwoods have been recognized: (1) wiregrass flatwoods, (2) cutthroat grass (Panicum abscissum) flatwoods, (3) pal metto flatwoods, (4) gall berry flatwoods, and (5) fern-south Florida slash pine(Woodwardia virginica and Osmunda cinnamomea/P. elliottii var. densa; Stout and Marion 1993). 
Appendix C: Plant TES Occurring in Flatwoods and Sandhills on Military Installations 
Table C1. Federally listed threatened, endangered, species at risk, candidate plant species, and species at risk occurring in flatwoods and sandhills on installations in the southeast region.

\begin{tabular}{|c|c|c|c|c|c|}
\hline Common Name & Scientific Name & Installation & $\begin{array}{l}\text { Federal } \\
\text { Status }\end{array}$ & $\begin{array}{l}\text { NWI } \\
\text { Class }\end{array}$ & Habitat/Community \\
\hline \multicolumn{6}{|l|}{ Woody Plants } \\
\hline Anise Tree, Yellow & Illicium parviflorum & NAS Jacksonville, FL & SAR & $\mathrm{OBL}$ & $\begin{array}{l}\text { Observed in disturbed pine flatwoods, probably an } \\
\text { ornamental planting (Environmental Services and } \\
\text { Permitting, Inc. 1990). Naturally occurs in low } \\
\text { woods and swamps (Small 1972). }\end{array}$ \\
\hline $\begin{array}{l}\text { Jointweed, Large- } \\
\text { leaved }\end{array}$ & $\begin{array}{l}\text { Polygonella } \\
\text { macrophylla }\end{array}$ & $\begin{array}{l}\text { NAS Pensacola and outlying } \\
\text { Bronson Field, FL }\end{array}$ & SAR & $\mathrm{NL}$ & $\begin{array}{l}\text { Sandy soils, usually in natural openings in scrubs, } \\
\text { occasionally observed in disturbances in sandhills; } \\
\text { disturbed areas (Johnson 1993b). }\end{array}$ \\
\hline Lead Plant, Georgia & $\begin{array}{l}\text { Amorpha georgiana } \\
\text { var. georgiana }\end{array}$ & $\begin{array}{l}\text { Camp Mackall and Fort Bragg, } \\
\text { NC }\end{array}$ & SAR & FACW & $\begin{array}{l}\text { Occurs primarily in pine/shrub wiregrass terraces } \\
\text { along rivers and streams, a type of mesic pine } \\
\text { flatwoods. Usually occurs at the ecotone between } \\
\text { the pine community and the floodplain. } \\
\text { Collections also include swamp forest, low } \\
\text { flatwoods, low wet pasture, and sandy wiregrass } \\
\text { savanna. The species favors clearings; often } \\
\text { small ones created by treefall or forest cutting } \\
\text { (Russo et al. 1993). Pocosins, ecotones, wet- } \\
\text { mesic savannas/flatwoods (Jordan et al. 1995). }\end{array}$ \\
\hline Maracao Cimarron & Brysonomia lucida & NAS Key West, FL & SAR & & $\begin{array}{l}\text { Low hammocks and pinelands, Florida Keys } \\
\text { (Small 1972). }\end{array}$ \\
\hline Nestronia & Nestronia umbellula & $\begin{array}{l}\text { Fort Benning, GA } \\
\text { Camp Mackall and Fort Bragg, } \\
\text { NC }\end{array}$ & SAR & NL & $\begin{array}{l}\text { Woods and streambanks, Piedmont to } \\
\text { Appalachian Plateau (Small 1972). }\end{array}$ \\
\hline Plume, Georgia & Elliotia racemosa & Fort Stewart, GA & SAR & NL & Oak ridges and sandhills (Small 1972). \\
\hline
\end{tabular}




\begin{tabular}{|c|c|c|c|c|c|}
\hline Common Name & Scientific Name & Installation & $\begin{array}{l}\text { Federal } \\
\text { Status }\end{array}$ & $\begin{array}{l}\text { NWI } \\
\text { Class }\end{array}$ & Habitat/Community \\
\hline $\begin{array}{l}\text { Rhododendron, } \\
\text { Chapman's }\end{array}$ & $\begin{array}{l}\text { Rhododendron } \\
\text { chapmanii }\end{array}$ & Camp Blanding, FL & $\mathrm{E}$ & $\mathrm{FACW}+$ & $\begin{array}{l}\text { Light shade to full sun, good drainage with no } \\
\text { chance of flooding, sandy soil with water table } \\
\text { near surface. Species always occurs adjacent to } \\
\text { a black titi (Cliftonia monophylla) bog, and always } \\
\text { occupies habitat between pine flatwoods and sand } \\
\text { pine scrub ("scrubby flatwoods") (USFWS 1983). }\end{array}$ \\
\hline Sumac, Michaux's & Rhus michauxii & $\begin{array}{l}\text { Camp Mackall and Fort Bragg, } \\
\text { NC }\end{array}$ & $\mathrm{E}$ & NL & $\begin{array}{l}\text { Sandy soils in openings, disturbed areas (USFWS } \\
\text { 1993b). Sites are slightly loamy but well drained } \\
\text { and occur throughout the sandhills in slight } \\
\text { depressions, swales, or along lower slopes; also } \\
\text { occurs in the Piedmont (Russo et al. 1993). }\end{array}$ \\
\hline White Wicky & Kalmia cuneata & $\begin{array}{l}\text { Camp Mackall and Fort Bragg, } \\
\text { NC }\end{array}$ & SAR & $\mathrm{FACW}_{+}$ & $\begin{array}{l}\text { Moist ecotones between streamhead pocosins } \\
\text { and sandhills. Also may occur at the margins or } \\
\text { within Carolina bays. Usually found on soils } \\
\text { having a long hydroperiod and overlain with a } \\
\text { layer of organic material. In well-burned areas } \\
\text { where shading is minimal (Russo et al. 1993). }\end{array}$ \\
\hline \multicolumn{6}{|l|}{ Forbs } \\
\hline Balduina, Purple & $\begin{array}{l}\text { Balduina } \\
\text { atropurpurea }\end{array}$ & Fort Stewart, GA & SAR & & Pitcher plant bogs, wet flatwoods, savannas. \\
\hline Bog-asphodel, Smooth & Tofieldia glabra & $\begin{array}{l}\text { Camp Mackall and Fort Bragg, } \\
\text { NC } \\
\text { MCB Camp Lejeune, NC }\end{array}$ & SAR & FACW & $\begin{array}{l}\text { Occurs on moist ecotones between streamhead } \\
\text { pocosins or herbaceous seeps/bogs and } \\
\text { sandhills; also occurs within savannas and wet } \\
\text { flatwoods, especially where they border wetlands. } \\
\text { Also can be found in open, disturbed habitats } \\
\text { (e.g., roadside ditches, powerline rights of way; } \\
\text { Russo et al. 1993). }\end{array}$ \\
\hline Bog Buttons, Southern & $\begin{array}{l}\text { Lachnocaulon } \\
\text { beyrichianum }\end{array}$ & Sunny Point MOT, NC & SAR & $\mathrm{OBL}$ & Sandy shores and springy places (Small 1972). \\
\hline
\end{tabular}




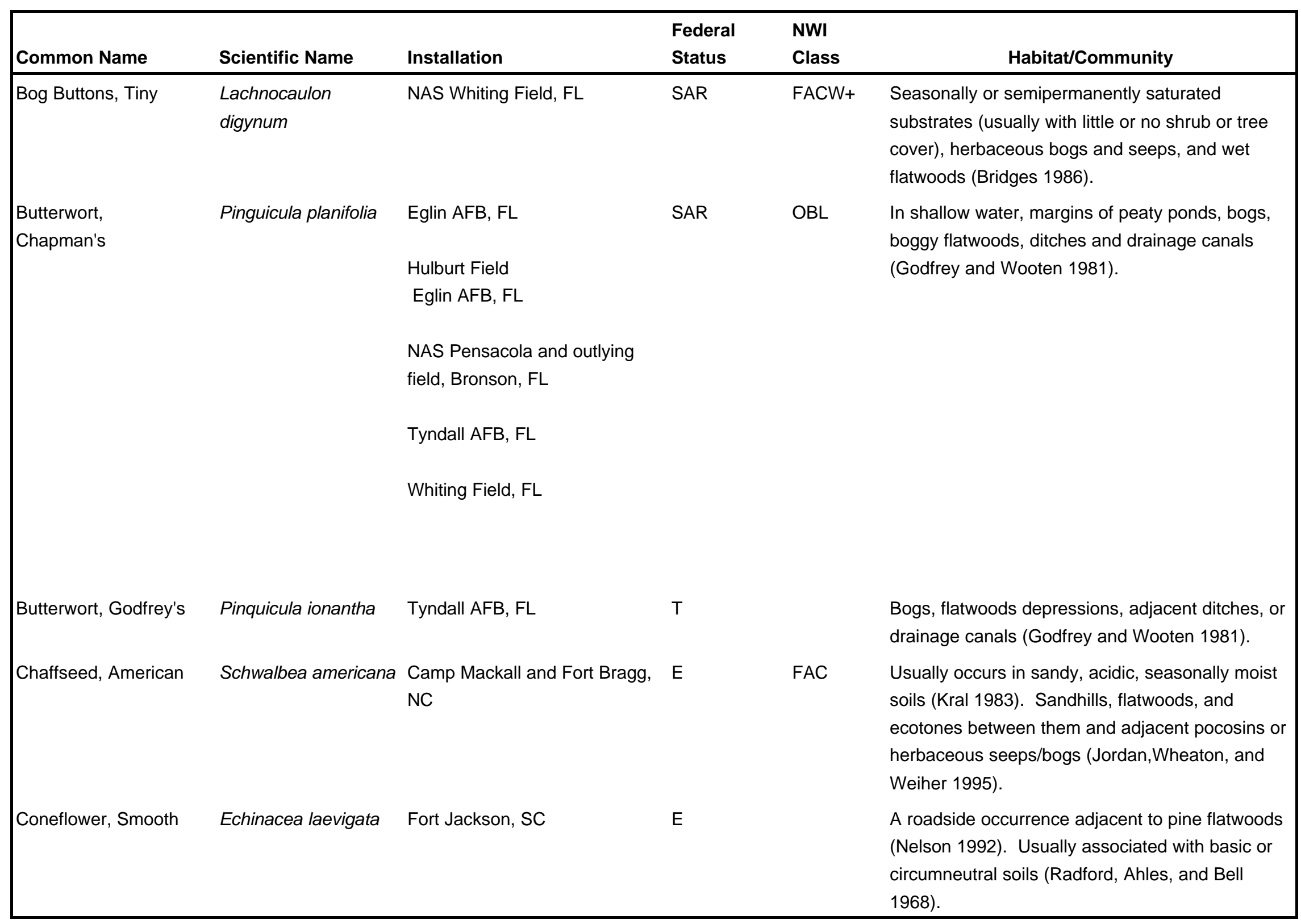




\begin{tabular}{|c|c|c|c|c|c|}
\hline Common Name & Scientific Name & Installation & $\begin{array}{l}\text { Federal } \\
\text { Status }\end{array}$ & $\begin{array}{l}\text { NWI } \\
\text { Class }\end{array}$ & Habitat/Community \\
\hline Coneflower, Yellow & $\begin{array}{l}\text { Rudbeckia nitida var. } \\
\text { nitida }\end{array}$ & Fort Stewart, GA & SAR & $\begin{array}{l}\text { variety not } \\
\text { listed }\end{array}$ & $\begin{array}{l}\text { This species occurs in moist to acidic clearings in } \\
\text { pinelands, either flatwoods or swales in sandhills } \\
\text { (Kral 1983). }\end{array}$ \\
\hline Cowbane, Piedmont & Oxypolis ternata & MCB Camp Lejeune, NC & SAR & OBL & $\begin{array}{l}\text { Wet flatwoods, pocosins, herbaceous seeps/bogs } \\
\text { ecotones between flatwoods or sandhills and } \\
\text { pocosins or herbaceous seeps/bogs; disturbed } \\
\text { areas (Jordan,Wheaton, and Weiher 1995). }\end{array}$ \\
\hline $\begin{array}{l}\text { Crownbeard, } \\
\text { Chapman's }\end{array}$ & Verbesina chapmanii & Tyndall AFB, FL & SAR & $\mathrm{FACW}_{+}$ & $\begin{array}{l}\text { Moist pine flatwoods. Confined to long hydro- } \\
\text { period, black, sandy-peaty soils, also at the edges } \\
\text { of boggy sites (Kral 1983); bogs, grassy cypress } \\
\text { depressions (Godfrey and Wooten 1981). }\end{array}$ \\
\hline $\begin{array}{l}\text { Crownbeard, Variable- } \\
\text { leaf }\end{array}$ & $\begin{array}{l}\text { Verbesina heter- } \\
\text { ophylla }\end{array}$ & NAS Cecil Field, FL & SAR & FACW & $\begin{array}{l}\text { Seasonally wet pine flatwoods (Godfrey and } \\
\text { Wooten 1981). Confined to somewhat drier sites } \\
\text { on flatwoods (Kral 1983). }\end{array}$ \\
\hline Eulophia & $\begin{array}{l}\text { Pteroglossaspis } \\
\text { ecristata }\end{array}$ & Fort Stewart, GA & SAR & NL & $\begin{array}{l}\text { Tolerates a wide range of moisture conditions, } \\
\text { from very xeric to seasonally inundated or almost } \\
\text { permanently saturated soils, but most records are } \\
\text { from sites that dry out, at least seasonally. Scrub } \\
\text { sandhills, flatwoods, and various natural and } \\
\text { human-disturbed open areas (Russo et al. 1993). }\end{array}$ \\
\hline Flax, West's & Linum westii & Eglin AFB, FL & SAR & OBL & $\begin{array}{l}\text { Boggy depressions in pine flatwoods, margins of } \\
\text { cypress ponds and depressions, St. John's-wort } \\
\text { bogs, adjacent ditches (Godfrey and Wooten, } \\
\text { 1981) }\end{array}$ \\
\hline Goldenrod, Carolina & Solidago pulchra & $\begin{array}{l}\text { MCAS Cherry Point, NC } \\
\text { MCB Camp Lejeune, NC }\end{array}$ & SAR & NL & $\begin{array}{l}\text { Wet or mesic flatwoods, and ecotones between } \\
\text { flatwoods and adjacent pocosins or herbaceous } \\
\text { seeps/bogs (Jordan, Wheaton, and Weiher 1995). } \\
\text { Occasionally occurs in savanna ditches, savanna } \\
\text { borrow scrape ecotones, powerline rights of way, } \\
\text { and roadsides (Russo et al. 1993). }\end{array}$ \\
\hline
\end{tabular}




\begin{tabular}{|c|c|c|c|c|c|}
\hline Common Name & Scientific Name & Installation & $\begin{array}{l}\text { Federal } \\
\text { Status }\end{array}$ & $\begin{array}{l}\text { NWI } \\
\text { Class }\end{array}$ & Habitat/Community \\
\hline $\begin{array}{l}\text { Goldenrod, Spring } \\
\text { Flowering }\end{array}$ & Solidago verna & $\begin{array}{l}\text { Camp Mackall and Fort Bragg, } \\
\text { NC } \\
\text { MCAS Cherry Point, NC }\end{array}$ & SAR & $\mathrm{OBL}$ & $\begin{array}{l}\text { Wet flatwoods, and ecotones between flatwoods } \\
\text { or sandhills and adjacent wetlands } \\
\text { (Jordan,Wheaton, and Weiher 1995); numerous } \\
\text { occurrences in disturbed areas (Russo et al. } \\
\text { 1993). }\end{array}$ \\
\hline $\begin{array}{l}\text { Grass of Parnassus, } \\
\text { Carolina }\end{array}$ & Parnassia caroliniana & $\begin{array}{l}\text { Camp Mackall and Fort Bragg, } \\
\text { NC }\end{array}$ & SAR & $\mathrm{OBL}$ & $\begin{array}{l}\text { Prefers low, permanently moist drainages in open, } \\
\text { herb-dominated grasslands (seeps/bogs, flat- } \\
\text { woods, savannas, and ecotones between } \\
\text { flatwoods or sandhills and adjacent wetlands); } \\
\text { also found in disturbed areas (Russo et al. 1993). }\end{array}$ \\
\hline Groovebur, Incised & Agrimonia incisa & $\begin{array}{l}\text { Fort Benning, GA } \\
\text { Fort Stewart, GA } \\
\text { MCLB Albany, GA }\end{array}$ & SAR & NL & $\begin{array}{l}\text { Sandy open woodlands, well-drained ravine } \\
\text { heads, bluffs and small clearings (Kral 1983); } \\
\text { Sandhills (Jordan,Wheaton, and Weiher 1995). }\end{array}$ \\
\hline Hoary-pea, Pineland & Tephrosia mohrii & Eglin AFB, FL & SAR & NL & Pinelands (Small 1972). \\
\hline $\begin{array}{l}\text { Loosestrife, Rough- } \\
\text { leaved }\end{array}$ & $\begin{array}{l}\text { Lysimachia } \\
\text { asperulaefolia }\end{array}$ & $\begin{array}{l}\text { Camp Mackall and Fort Bragg, } \\
\text { NC } \\
\text { MCB Camp Lejeune, NC }\end{array}$ & $E$ & $\mathrm{OBL}$ & $\begin{array}{l}\text { Ecotones between longleaf pine uplands } \\
\text { (flatwoods and sandhills) and pocosins or } \\
\text { herbaceous seeps/bogs in moist, sandy, or peaty } \\
\text { soils with low vegetation that allows for abundant } \\
\text { sunlight in the herb layer. Also occurs in } \\
\text { disturbed areas (Russo et al. 1993). }\end{array}$ \\
\hline $\begin{array}{l}\text { Meadow-beauty, } \\
\text { Awned }\end{array}$ & Rhexia aristosa & MCB Camp Lejeune, NC & SAR & $\mathrm{OBL}$ & $\begin{array}{l}\text { Wet/mesic flatwoods, margins of ponds or } \\
\text { depressions in pinelands, swamps; disturbed } \\
\text { areas (Jordan,Wheaton, and Weiher 1995); } \\
\text { Carolina bays, cypress savannas (LeBlond, } \\
\text { Fussel, and Braswell 1994a). }\end{array}$ \\
\hline
\end{tabular}




\begin{tabular}{|c|c|c|c|c|c|}
\hline Common Name & Scientific Name & Installation & $\begin{array}{l}\text { Federal } \\
\text { Status }\end{array}$ & $\begin{array}{l}\text { NWI } \\
\text { Class }\end{array}$ & Habitat/Community \\
\hline Milk-vetch, Sandhills & Astragalus michauxii & $\begin{array}{l}\text { Camp Mackall and Fort Bragg, } \\
\text { NC }\end{array}$ & SAR & NL & $\begin{array}{l}\text { Sandhills (Jordan, Wheaton, and Weiher 1995); } \\
\text { does not appear to colonize disturbed sites and } \\
\text { has low tolerance for disturbance in existing sites } \\
\text { (Russo et al. 1993). }\end{array}$ \\
\hline Milkweed, Southern & Asclepias viridula & Eglin AFB, FL & C & FACW- & $\begin{array}{l}\text { Moist, acidic pineland savanna; substrate is fine } \\
\text { sand that stays moist or wet throughout most of } \\
\text { the year (Kral 1983). }\end{array}$ \\
\hline Monkey-face & $\begin{array}{l}\text { Platanthera } \\
\text { integrilabia }\end{array}$ & Fort McClellan, Main Post, AL & SAR & $\mathrm{OBL}$ & $\begin{array}{l}\text { Wet, flat, boggy areas at the head of streams or } \\
\text { on seepage slopes. Usually associated with } \\
\text { sphagnum moss (Sphagnum spp.) and usually } \\
\text { grows in partial shade (Shea 1992). }\end{array}$ \\
\hline $\begin{array}{l}\text { Morning Glory, } \\
\text { Pickering's }\end{array}$ & $\begin{array}{l}\text { Stylisma pickeringii } \\
\text { var pickeringii }\end{array}$ & $\begin{array}{l}\text { Fort Benning, GA } \\
\text { Fort Gordon, GA } \\
\text { Camp Mackall and } \\
\text { Fort Bragg, NC }\end{array}$ & SAR & NL & $\begin{array}{l}\text { Dry to xeric, nutrient-poor, well-drained, coarse } \\
\text { sandy soils with little competing vegetation or } \\
\text { litter; areas where tree cover is sparse to non- } \\
\text { existent. Occurs in xeric sandhills and on ex- } \\
\text { posed bluffs; often found in sparsely vegetated } \\
\text { disturbed areas (e.g., roadsides, drop zones, tank } \\
\text { training sites; Russo et al. 1993). }\end{array}$ \\
\hline $\begin{array}{l}\text { Pitcher Plant, White- } \\
\text { topped }\end{array}$ & $\begin{array}{l}\text { Sarracenia } \\
\text { leucophylla }\end{array}$ & $\begin{array}{l}\text { Eglin AFB, FL } \\
\text { Hulburt Field, Eglin AFB, FL } \\
\text { NAS Pensacola, FL }\end{array}$ & SAR & OBL & $\begin{array}{l}\text { Bogs, wet flatwoods, boggy borders of branch } \\
\text { bays and cypress depressions, boggy areas by } \\
\text { small streams (Godfrey and Wooten 1981). } \\
\text { Areas that are wet almost year-round (TESII } \\
\text { 1994). }\end{array}$ \\
\hline Pyxie-moss, Well's & $\begin{array}{l}\text { Pyxidanthera } \\
\text { barbulata var. } \\
\text { brevifolia }\end{array}$ & $\begin{array}{l}\text { Camp Mackall and Fort Bragg, } \\
\text { NC }\end{array}$ & SAR & NL & $\begin{array}{l}\text { Xeric, thinly wooded sterile sands (Russo et al. } \\
\text { 1993). }\end{array}$ \\
\hline Savory, Toothed & Calamintha dentata & Eglin AFB, FL & SAR & $\mathrm{NL}$ & Sandhills (FNAI 1994). \\
\hline
\end{tabular}




\begin{tabular}{|c|c|c|c|c|c|}
\hline Common Name & Scientific Name & Installation & $\begin{array}{l}\text { Federal } \\
\text { Status }\end{array}$ & $\begin{array}{l}\text { NWI } \\
\text { Class }\end{array}$ & Habitat/Community \\
\hline Spurge, Porter's & $\begin{array}{l}\text { Chamaescyce } \\
\text { porteriana var. } \\
\text { scoparia }\end{array}$ & $\begin{array}{l}\text { Naval Communications Unit, } \\
\text { Saddlebunch Key, FL }\end{array}$ & SAR & & Pine flatwoods (Dave Martin, pers. comm.). \\
\hline Venus' Flytrap & Dionaea muscipula & $\begin{array}{l}\text { Camp Mackall and Fort Bragg, } \\
\text { NC } \\
\text { MCB Camp Lejeune, NC }\end{array}$ & SAR & FACW & $\begin{array}{l}\text { Wet/mesic flatwoods, ecotones between } \\
\text { flatwoods or sandhills and adjacent pocosins or } \\
\text { herbaceous seeps/bogs, disturbed areas (Jordan, } \\
\text { Wheaton, and Weiher 1995). }\end{array}$ \\
\hline Wild Indigo, Hairy & $\begin{array}{l}\text { Baptisia calycosa var. } \\
\text { villosa }\end{array}$ & $\begin{array}{l}\text { Eglin AFB, FL } \\
\text { NAS Whiting Field, FL }\end{array}$ & SAR & NL & $\begin{array}{l}\text { Dry, sandy pinelands (Small 1972) or oak woods; } \\
\text { also along roadsides, railroads, powerlines (Isley } \\
\text { 1990). }\end{array}$ \\
\hline $\begin{array}{l}\text { Yellow-eyed Grass, } \\
\text { Drummond's }\end{array}$ & Xyris drummondii & $\begin{array}{l}\text { Eglin AFB, FL } \\
\text { Tyndall AFB, FL }\end{array}$ & SAR & OBL & $\begin{array}{l}\text { Bogs or boggy places where soil moisture is high; } \\
\text { it is always in full sun. Pitcher plant bogs in } \\
\text { flatwoods are ideal. Also found in areas with } \\
\text { clearcutting (Kral 1983). Moist acid sands, sandy } \\
\text { peats, or sphagnous peats (Godfrey and Wooten } \\
\text { 1981). }\end{array}$ \\
\hline $\begin{array}{l}\text { Yellow-eyed Grass, } \\
\text { Harper's }\end{array}$ & Xyris scabrifolia & Tyndall AFB, FL & SAR & $\mathrm{OBL}$ & $\begin{array}{l}\text { Moist to wet sandy peats (Russo et al. 1993). } \\
\text { Pocosins, herbaceous seeps/bogs and ecotones } \\
\text { between these communities and flatwoods or } \\
\text { sandhills (Jordan,Wheaton, and Weiher 1995). }\end{array}$ \\
\hline $\begin{array}{l}\text { Yellow-eyed Grass, } \\
\text { Quillwort }\end{array}$ & Xyris isoetifolia & Tyndall AFB, FL & SAR & $\mathrm{OBL}$ & $\begin{array}{l}\text { Moist sands or sandy peat of savanna bogs, } \\
\text { flatwoods pond margins, and lakeshores (Godfrey } \\
\text { and Wooten 1981). }\end{array}$ \\
\hline \multicolumn{6}{|c|}{ Grasses, Rushes and Sedges } \\
\hline Dropseed, Pine Barrens & $\begin{array}{l}\text { Sporobolus } \\
\text { sp. } 1\end{array}$ & MCB Camp Lejeune, NC & SAR & NL & $\begin{array}{l}\text { Wet flatwoods, savannas, small depression } \\
\text { pocosins, and pond margins (LeBlond, Fussell, } \\
\text { and Braswell 1994a). }\end{array}$ \\
\hline
\end{tabular}




\begin{tabular}{|c|c|c|c|c|c|}
\hline Common Name & Scientific Name & Installation & $\begin{array}{l}\text { Federal } \\
\text { Status }\end{array}$ & $\begin{array}{l}\text { NWI } \\
\text { Class }\end{array}$ & Habitat/Community \\
\hline Grass, Curtis' Sand & Calamovilfa curtissii & $\begin{array}{l}\text { Eglin AFB, FL } \\
\text { Hulburt Field, Eglin AFB, FL } \\
\text { NAS Whiting Field. FL }\end{array}$ & SAR & FAC & $\begin{array}{l}\text { Most often found in ecotone between flatwoods } \\
\text { and wetter areas that have wiregrass (A. } \\
\text { beytrichiana) as the most common species. } \\
\text { Occurs as a band around ponds, in the zone } \\
\text { between titi (Cyrilla racemiflora) and saw } \\
\text { palmetto. In ponds surrounded by sandhills or } \\
\text { scrub, it may fill the entire depression (Johnson } \\
\text { 1993a). }\end{array}$ \\
\hline $\begin{array}{l}\text { Grass, Florida } \\
\text { Toothache }\end{array}$ & Ctenium floridanum & NAS Cecil Field, FL & SAR & FACW & $\begin{array}{l}\text { Seasonally wet pine savannas, flatwoods, bogs } \\
\text { (Godfrey and Wooten 1981). }\end{array}$ \\
\hline $\begin{array}{l}\text { Grass, Southern } \\
\text { Threeawn }\end{array}$ & Aristida simpliciflora & $\begin{array}{l}\text { Eglin AFB, FL } \\
\text { Camp Shelby, MS }\end{array}$ & SAR & FAC- & Moist pine woods (Small 1972). \\
\hline Sedge, Umbrella & Cyperus grayoides & Fort Polk, LA & SAR & NL & Full sun sites in sandhills (Hart and Lester 1993). \\
\hline
\end{tabular}

Legend:

Federal Rankings: $\mathrm{E}=$ Endangered; $\mathrm{T}=$ Threatened; $\mathrm{C}=$ Candidate Species (formerly C1 species); SAR = Species at Risk (formerly C2/C3 species);

NWI (National Wetland Indicator) Class:

OBL = Obligate Wetland $=$ occurs with an estimated $99 \%$ probability in wetlands

FACW $=$ Facultative Wetland $=$ an estimated 67 to $99 \%$ probability of occurrence in wetlands

$F A C=$ Facultative $=$ equally likely to occur in wetlands and nonwetlands ( 34 to $66 \%$ probability)

$\mathrm{NL}=$ Not listed

A positive sign (+) indicates a frequency toward the higher end of a category (more frequently found in wetlands), and a negative sign ( -$)$ indicates a frequency toward the lower end of a category (less frequently found in wetlands).

Source: Reed, P.B., Jr., 1988. 



\section{Appendix D: Animal TES Occurring in Flatwoods and Sandhills on Military Installations}


Table D1. Federally listed candidate animal species, and animal species at risk known to occur in the Longleaf Pine-Turkey Oak sandhills community On at least one military installation in the southeastern United States.

\begin{tabular}{|c|c|c|c|c|c|}
\hline Common Name & Scientific Name & Installation & $\begin{array}{l}\text { Fed. } \\
\text { Status }\end{array}$ & $\begin{array}{l}\text { Status on } \\
\text { Installation }\end{array}$ & Habitat/ Community \\
\hline \multicolumn{6}{|l|}{ Mammals } \\
\hline $\begin{array}{l}\text { Bear, Florida } \\
\text { Black }\end{array}$ & $\begin{array}{l}\text { Ursus americanus } \\
\text { floridanus }\end{array}$ & $\begin{array}{l}\text { Eglin AFB, FL } \\
\text { Camp Blanding, FL }\end{array}$ & SAR & $\begin{array}{l}\text { Documented } \\
\text { Documented }\end{array}$ & \\
\hline $\begin{array}{l}\text { Bear, Louisiana } \\
\text { Black }\end{array}$ & $\begin{array}{l}\text { Ursus americanus } \\
\text { luteolus }\end{array}$ & & & & $\begin{array}{l}\text { Primarily bottomland hardwood forests, but has been } \\
\text { documented using coastal flatwoods habitats. }\end{array}$ \\
\hline $\begin{array}{l}\text { Squirrel, } \\
\text { Sherman's Fox }\end{array}$ & Sciurus niger shermani & $\begin{array}{l}\text { Camp Blanding, FL } \\
\text { Avon Park, FL }\end{array}$ & SAR & Documented & $\begin{array}{l}\text { Primarily longleaf pine-turkey oak sandhills characterized } \\
\text { by large, well-spaced pines and an understory of scattered } \\
\text { or clumped oaks, although they may also be found in other } \\
\text { open pine stands, mixed pine-hardwood forests, and in } \\
\text { ecotones between forest types. }\end{array}$ \\
\hline \multicolumn{6}{|l|}{ Birds } \\
\hline Eagle, Bald & $\begin{array}{l}\text { Haliaeetus } \\
\text { leucocephalus }\end{array}$ & $\begin{array}{l}\text { Anniston Army Depot, AL } \\
\text { Fort Rucker, AL } \\
\text { Redstone Arsenal, AL } \\
\text { NAS Jacksonville, FL } \\
\text { NAS Key West, FL } \\
\text { Eglin AFB, FL } \\
\text { Camp Blanding, FL } \\
\text { Fort Benning, GA } \\
\text { Fort Stewart, GA } \\
\text { Fort Gordon, GA } \\
\text { Savannah Army Depot, GA } \\
\text { Barksdale AFB, LA } \\
\text { Louisiana AAP, LA } \\
\text { MOT Sunny Point, NC } \\
\text { Fort Bragg, NC } \\
\text { Charleston NWS, SC } \\
\text { Fort Jackson, SC } \\
\text { Fort Belvoir, VA } \\
\text { Fort Lee, VA } \\
\text { Fort A.P. Hill }\end{array}$ & $\mathrm{T}$ & $\begin{array}{l}\text { Potential } \\
\text { Potential } \\
\text { Potential } \\
\text { Documented } \\
\text { Potential } \\
\text { Potential } \\
\text { Documented } \\
\text { Documented } \\
\text { Documented } \\
\text { Potential } \\
\text { Documented } \\
\text { Potential } \\
\text { Potential } \\
\text { Documented } \\
\text { Potential } \\
\text { Potential } \\
\text { Potential } \\
\text { Documented } \\
\text { Potential } \\
\text { Potential }\end{array}$ & $\begin{array}{l}\text { Nests are almost always associated with creeks, rivers, } \\
\text { and large bodies of water. Most nests in Florida occur in } \\
\text { live or dead pine trees (mainly longleaf, slash, loblolly, and } \\
\text { sand pines). Wintering bald eagles are most often } \\
\text { associated with riparian and open water areas that provide } \\
\text { an ample food supply and have adequate nocturnal roost } \\
\text { sites. Bald eagles have also been reported to spend a } \\
\text { substantial portion of winter in more terrestrial, inland } \\
\text { habitats hunting small prey and scavenging livestock and } \\
\text { wildlife. }\end{array}$ \\
\hline
\end{tabular}




\begin{tabular}{|c|c|c|c|c|c|}
\hline Common Name & Scientific Name & Installation & $\begin{array}{l}\text { Fed. } \\
\text { Status }\end{array}$ & $\begin{array}{l}\text { Status on } \\
\text { Installation }\end{array}$ & Habitat/ Community \\
\hline $\begin{array}{l}\text { Kestrel, } \\
\text { Southeastern } \\
\text { American }\end{array}$ & Falco sparverius paulus & $\begin{array}{l}\text { Fort Rucker, AL } \\
\text { Anniston AD, AL } \\
\text { Camp Blanding, FL } \\
\text { Eglin AFB, FL } \\
\text { Fort Gordon, GA } \\
\text { Fort Benning, GA } \\
\text { Louisiana AAP, LA } \\
\text { Fort Jackson, SC }\end{array}$ & SAR & $\begin{array}{l}\text { Potential } \\
\text { Potential } \\
\text { Documented } \\
\text { Potential } \\
\text { Documented } \\
\text { Potential } \\
\text { Documented } \\
\text { Documented }\end{array}$ & $\begin{array}{l}\text { Found in open habitats, primarily in open pasture-like } \\
\text { areas that include dead trees (i.e., snags). Also prefer } \\
\text { open longleaf pine-turkey oak sandhill communities, } \\
\text { agriculturallmixed hardwood communities, pine flatwoods, } \\
\text { grasslands, pastures, open sites within suburban and } \\
\text { residential areas (e.g., golf courses, parks), edges of river } \\
\text { bottoms, and along coastal regions. }\end{array}$ \\
\hline $\begin{array}{l}\text { Sparrow, } \\
\text { Bachman's }\end{array}$ & Aimophila aestivalis & $\begin{array}{l}\text { Anniston AD, AL } \\
\text { Fort Rucker, AL } \\
\text { Eglin AFB, FL } \\
\text { Camp Blanding, FL } \\
\text { Fort Stewart, GA } \\
\text { Fort Gordon, GA } \\
\text { Fort Benning, GA } \\
\text { MCLB Albany, GA } \\
\text { Camp Beauregard, LA } \\
\text { Fort Polk, LA } \\
\text { Camp Shelby, MS } \\
\text { Fort Bragg, NC } \\
\text { Fort Jackson, SC } \\
\text { Fort Pickett, VA } \\
\text { Fort A.P. Hill, VA }\end{array}$ & SAR & $\begin{array}{l}\text { Potential } \\
\text { Potential } \\
\text { Documented } \\
\text { Documented } \\
\\
\text { Documented } \\
\text { Documented } \\
\text { Documented } \\
\text { Documented } \\
\\
\text { Documented } \\
\text { Documented }\end{array}$ & $\begin{array}{l}\text { Found in a variety of breeding habitats, including old } \\
\text { deserted fields having dense grasses. Nests are typically } \\
\text { in dry, open longleaf or shortleaf pine woods with a grassy } \\
\text { herbaceous layer consisting of bluestems and forbs, and } \\
\text { scattered shrubs or saw palmetto. In winter, scrub oak, } \\
\text { open broom sedge fields, fence rows, and wet upland } \\
\text { edges of river swamps and saltwater shores are used. }\end{array}$ \\
\hline
\end{tabular}




\begin{tabular}{|c|c|c|c|c|c|}
\hline Common Name & Scientific Name & Installation & $\begin{array}{l}\text { Fed. } \\
\text { Status }\end{array}$ & $\begin{array}{l}\text { Status on } \\
\text { Installation }\end{array}$ & Habitat/ Community \\
\hline $\begin{array}{l}\text { Woodpecker, } \\
\text { Red-Cockaded }\end{array}$ & Picoides borealis & $\begin{array}{l}\text { Camp Blanding, FL } \\
\text { Eglin AFB, FL } \\
\text { Fort Benning, GA } \\
\text { Fort Stewart, GA } \\
\text { Fort Gordon, GA } \\
\text { MCLB Albany, GA } \\
\text { Fort Jackson, SC } \\
\text { NWS Charleston, SC } \\
\text { Camp Shelby, MS } \\
\text { MOT Sunny Point, NC } \\
\text { Fort Bragg, NC } \\
\text { Fort McClellan, AL } \\
\text { Fort Polk, LA } \\
\text { Louisiana AAD, LA }\end{array}$ & $E$ & $\begin{array}{l}\text { Potential } \\
\text { Documented } \\
\text { Documented } \\
\text { Documented } \\
\text { Potential } \\
\text { Potential } \\
\text { Documented } \\
\text { Documented } \\
\\
\text { Documented } \\
\text { Documented } \\
\text { Potential } \\
\text { Documented } \\
\text { Potential }\end{array}$ & $\begin{array}{l}\text { Inhabit open, mature pine woodlands maintained by low- } \\
\text { intensity fire during the growing season. Optimal habitat is } \\
\text { characterized as a broad savanna with a scattered } \\
\text { overstory of large pine trees and a dense, diverse } \\
\text { groundcover of grasses, forbs, and shrubs (Hooper, } \\
\text { Robinson, and Jackson 1980, Jordan, Wheaton, and } \\
\text { Wieher 1995). }\end{array}$ \\
\hline \multicolumn{6}{|l|}{ Reptiles } \\
\hline
\end{tabular}




\begin{tabular}{|c|c|c|c|c|c|}
\hline Common Name & Scientific Name & Installation & $\begin{array}{l}\text { Fed. } \\
\text { Status }\end{array}$ & $\begin{array}{l}\text { Status on } \\
\text { Installation }\end{array}$ & Habitat/ Community \\
\hline $\begin{array}{l}\text { Snake, Pine } \\
\text { (Florida, Black, } \\
\text { Northern) }\end{array}$ & $\begin{array}{l}\text { Pituophis melanoleucus } \\
\text { mugitus }\end{array}$ & $\begin{array}{l}\text { Anniston AD, AL } \\
\text { Camp Blanding, FL } \\
\text { Eglin AFB, FL } \\
\text { Fort Stewart, GA } \\
\text { Fort Gordon, GA } \\
\text { Fort Benning, GA } \\
\text { Fort Polk, LA } \\
\text { Camp Shelby, MS } \\
\text { Fort Bragg, NC } \\
\text { Camp Mackall, NC } \\
\text { Fort Jackson, SC }\end{array}$ & SAR & $\begin{array}{l}\text { Potential } \\
\text { Documented } \\
\text { Documented } \\
\text { Documented } \\
\text { Documented } \\
\text { Documented } \\
\text { Potential }\end{array}$ & $\begin{array}{l}\text { Typically found in areas of sandy soil dominated by scrub } \\
\text { pines and shrubs, flat sandy pine barrens, sandhills, and } \\
\text { dry mountain ridges, longleaf pine sandhills, sandy old } \\
\text { fields, turkey oak-pine forests. In Louisiana, both black } \\
\text { and Louisiana pine snakes are restricted to longleaf pine } \\
\text { forests and second growth longleaf pine-blackjack oak (Q. } \\
\text { marilandica) associations. Louisiana pine snakes have } \\
\text { been observed foraging in a seasonally dry, acid bog in } \\
\text { Texas. The Florida pine snake is found in xeric sites, } \\
\text { occurring primarily in longleaf pine-turkey oak woodlands, } \\
\text { but also in sand pine scrub, pine flatwoods on well-drained } \\
\text { soils, and old fields on former sandhill sites. }\end{array}$ \\
\hline Tortoise, Gopher & Gopherus polyphemus & $\begin{array}{l}\text { Fort Rucker, AL } \\
\text { Orlando Naval } \\
\text { Training Center, FL } \\
\text { Eglin AFB, FL } \\
\text { Camp Blanding, FL } \\
\text { Fort Benning, GA } \\
\text { Fort Stewart, GA } \\
\text { MCLB Albany, GA } \\
\text { Fort Gordon, GA } \\
\text { Camp Shelby, MS }\end{array}$ & $\mathrm{SAR} / \mathrm{T}$ & $\begin{array}{l}\text { Documented } \\
\text { Documented }\end{array}$ & $\begin{array}{l}\text { Occupies a wide range of open, upland habitats with a } \\
\text { well-drained, deep sandy substrate, primarily longleaf pine- } \\
\text { xerophytic oak woodlands (sandhills) but also xeric } \\
\text { hammock, sand pine and oak scrub, pine flatwoods, } \\
\text { coastal grasslands, dry prairie, and a variety of ruderal and } \\
\text { successional habitat types. These habitats are suitable for } \\
\text { construction of its extensive burrows, provide ample } \\
\text { herbaceous vegetation for food, and sunny areas for } \\
\text { nesting and thermoregulation. Usually abandons densely } \\
\text { canopied areas and also can be found in disturbed habitats } \\
\text { such as roadsides, fence rows, old fields, and the edges of } \\
\text { overgrown (unburned) uplands. }\end{array}$ \\
\hline \multicolumn{6}{|l|}{ Amphibians } \\
\hline $\begin{array}{l}\text { Frog, Gopher } \\
\text { (Dusky, } \\
\text { Carolina, } \\
\text { Florida) }\end{array}$ & Rana areolata spp. & $\begin{array}{l}\text { Camp Blanding, FL } \\
\text { Eglin AFB, FL } \\
\text { Fort Stewart, GA } \\
\text { Fort Gordon, GA } \\
\text { Fort Benning, GA } \\
\text { Camp Shelby, MS } \\
\text { Fort Bragg, NC } \\
\text { Camp Mackall, NC } \\
\text { MOT Sunny Point, NC }\end{array}$ & C/SAR & $\begin{array}{l}\text { Documented } \\
\text { Documented } \\
\text { Potential } \\
\text { Documented } \\
\text { Potential }\end{array}$ & $\begin{array}{l}\text { Gopher frogs breed in ephemeral to semi-permanent } \\
\text { graminoid-dominated wetlands that lack large predatory } \\
\text { fish. Also have been observed breeding in ditches and } \\
\text { borrow pits, and have been heard calling from a recently } \\
\text { re-filled, normally permanent wetland following an extreme } \\
\text { drought. The reproductive habitat is best described as a } \\
\text { circular or near-circular depression marsh, ranging from } \\
0.4 \text { ha to } 33.5 \text { ha. Pocosins and riparian stream corridors } \\
\text { interlaced with longleaf pine communities are considered } \\
\text { quality habitat in North Carolina. }\end{array}$ \\
\hline
\end{tabular}




\begin{tabular}{|c|c|c|c|c|c|}
\hline Common Name & Scientific Name & Installation & $\begin{array}{l}\text { Fed. } \\
\text { Status }\end{array}$ & $\begin{array}{l}\text { Status on } \\
\text { Installation }\end{array}$ & Habitat/Community \\
\hline $\begin{array}{l}\text { Salamander, } \\
\text { Flatwoods }\end{array}$ & Ambystoma cingulatum & $\begin{array}{l}\text { Eglin AFB, FL } \\
\text { Camp Blanding, FL } \\
\text { Fort Stewart, GA } \\
\text { Marine Corps Logistics } \\
\text { Base, GA }\end{array}$ & SAR & $\begin{array}{l}\text { Documented } \\
\text { Documented }\end{array}$ & $\begin{array}{l}\text { Breeding sites can include roadside ditches and borrow } \\
\text { pits, typically encircled by a wiregrass-dominated } \\
\text { graminaceous ecotone. Larvae occur in acidic, tannin- } \\
\text { stained ephemeral wetlands (swamps or graminoid- } \\
\text { dominated depressions) up to } 9.5 \text { ha, and are usually } \leq 0.5 \\
\mathrm{~m} \text { deep. The overstory is typically dominated by pond } \\
\text { cypress (Taxodium ascendens), blackgum (Nyssa sylvatica } \\
\text { var. biflora), and slash pine. Post-larval salamanders } \\
\text { inhabit mesic longleaf pine-wiregrass flatwoods and } \\
\text { savannas. The terrestrial habitat is best described as a } \\
\text { topographically flat or slightly rolling wiregrass-dominated } \\
\text { grassland having little to no midstory and an open } \\
\text { overstory of widely scattered longleaf pine. High quality } \\
\text { occurrences include several wetlands within a matrix of } \\
\text { pine flatwoods and savanna. }\end{array}$ \\
\hline
\end{tabular}




\section{Appendix E: Class A Foams}

Not all Class A foams are approved for use. Those foams that are approved have "NFPA Standard 298" or "U.S. Forest Service Qualified/Approved Wildland Fire Foams" on the label or in the enclosed literature (R. Stanton, pers. comm., 1995).

A foam newsletter, entitled "Foam Applications for Wildland \& Urban Fire Management," reviews foam products. F ree copies can be obtained by contacting: Program Leader, Fire Management, USDA Forest Service, Technology and Devel opment Center, 444 E ast Bonita Avenue, San Dimas, CA 91773-3198, phone: (909)599-1267, Fax: (909)592-2309, product number DG, SDTDC:WO7A. 


\section{Distribution}

Chief of Engineers

ATTN: CEHEC-IM-LH (2)

ATTN: CEHEC-IM-LP (2)

ATTN: CERD-L

ATTN: CERD-M

ATTN: CECC-R

ATTN: CEMP-M

HQ ACSIM 20310-0600

ATTN: DAIM-ED-N (2)

HQDA 20310-0400

ATTN: DAMO-TRO

US Army Europe

ATTN: AEAEN-FE-E 09014

29th Area Support Group

ATTN: AERAS-FA 09054

CMTC Hohenfels 09173

ATTN: AETTH-DPW

FORSCOM

Fts Gillem \& McPherson 30330

ATTN: CEE

ATTN: AFOP-TE

ATTN: AFOP-TSR

ATTN: AFPI-ENE

Installations:

Fort Indiantown Gap 17003 ATTN: AFZS-FIG-PW

Fort AP Hill 22427 ATTN: AFZM-FHE

Fort McPherson 30330 ATTN: AFPI-EN

Fort Riley 66441 ATTN: AFZN-DE-V-N

Fort Polk 71459 ATTN: AFZH-DE-EN

Fort Sam Houston 78234 ATTN: AFZG-DE-EM

Fort Lewis 98433 ATTN: AFZH-DE-Q

Fort Carson 80913 ATTN: AFZC-ECM-NR

Fort Bragg 28307 ATTN: AFZA-PW (5)

Fort Campbell 42223 ATTN: AFZB-DPW-E

Fort McCoy 54656 ATTN: AFZR-DE-E

Fort Pickett 23824 ATTN: AFZA-FP-E

Fort Stewart 31314 ATTN: AFZP-DEV

Fort Buchanan 00934 ATTN: AFZK-B-EHE

Fort Devens 01433 ATTN: AFZD-DEM

Fort Drum 13602 ATTN: AFZS-EH-E

Fort Irwin 92310 ATTN: AFZJ-EHE-EN

Fort Hood 76544 ATTN: AFZF-DE-ENV

Fort Meade 20755 ATTN: ANME-PWR

Fort Hunter Liggett 93928 ATTN: AFZW-HE-DE

Yakima Trng Ctr 98901-5000 ATTN: AFZH-Y-ENR

Charles E. Kelly Spt Activity 15071 ATTN: AFIS-CK-EH

TRADOC
Fort Monroe 23651 ATTN: ATBO-G ATTN: ATBO-L Installations:

Fort Dix 08640 ATTN: ATZD-EHN

Fort Lee 23801 ATTN: ATZM-EPE

Fort Jackson 29207 ATTN: ATZJ-PWN

Fort Gordon 30905 ATTN: ATZH-DIE

Fort Benning 31905 ATTN: ATZB-PWN

Fort Hamilton 11252 ATTN: ATZD-FHE

Fort McClellan 36205 ATTN: ATZN-EM

Fort Rucker 36362 ATTN: ATZQ-DPW-EN

Fort Leonard Wood 64573 ATTN: ATZT-DPW-EE

Fort Leavenworth 66027 ATTN: ATZL-GCE

Fort Bliss 79916 ATTN: ATZC-DOE

Fort Monroe 23651 ATTN: ATZG-ISE

Carlisle Barracks 17013 ATTN: ATZE-DPW-E

Fort Eustis 23604 ATTN: ATZF-PWE

Fort Chaffee 72905 ATTN: ATZR-ZF

Fort Sill 73503 ATTN: ATZR-B

Fort Huachuca 85613 ATTN: ATZS-EHB

Fort Knox 40121 ATTN: ATZK-PWE

Fort Story 23459 ATTN: ATZF-EMI-S

US Air Force Command ATTN: Envr/Natural Res Ofc Andrews AFB 20031 Wright-Patterson AFB 45433 Randolph AFB 78150 Maxwell AFB 36112 Elmendorf AFB 99506 Scott AFB 62225 Hickam AFB 96853 Peterson AFB 80914 Bolling AFB 20332

US Air Force Air Combat Command Avon Park AF Range, FL 33825-5700 ATTN: 6 CSS/CEN

Beale AFB, CA 95903-1708 ATTN: 9 CES/CEV

Barksdale AFB, LA 71110-2078 ATTN: 2 CES/CEVC

Davis-Monthan AFB, AZ 85707-3920 ATTN: 355 CES/CEV

Dyess AFB, TX 79607-1670 ATTN: 7 CES/CEVA

Ellsworth AFB, SD 57706-5000 ATTN: 28 CES/CEV

Hollomon AFB, NM 88330-8458 ATTN: 49 CES/CEV

Langley AFB, VA 23665-2377 ATTN: 1 CES/CEV

Little Rock AFB, AR 72099-5154 ATTN: 314 CES/CEV
MacDill AFB, FL 33621-5207

ATTN: 6 CES/CEV

Cannon AFB, NM 88103-5136

ATTN: 27 CES/CEV

Minot AFB, ND 58705-5006 ATTN: 5 CES/CEV

Moody AFB, GA 31699-1707 ATTN: 347 CES/CEV

Nellis AFB, NV 89191-6546 ATTN: WTC/EVR

Offutt AFB, NE 68113-4019 ATTN: 55 CES/CEV

Pope AFB, NC 28308-2890 ATTN: 23 CES/CEV

Mountain Home AFB, ID 83648-5442 ATTN: 366 CES/CEV

Seymour Johnson AFB, NC 27531-2355 ATTN: 4 CES/CEV

Shaw AFB, SC 29152-5123 ATTN: 20 CES/CEV

Whiteman AFB, MO 65305-5060 ATTN: 509 CES/CEV

HQ US Army - Pacific (USARPAC)

DCSENGR - ATTN: APEN-IV

ATTN: APOP-TR

Fort Shafter, HI 96858

Fort Richardson, AK 99505

Fort Wainright, AK 99703

Fort Greely, AK 98733

USAMC Instal \& Srvc Activity ATTN: AMXEN-U 61299

US Army Armament, Munitions and Chemical Cmd ATTN: AMSMC-ENR ATTN: AMSMC-EQC

US Army Aviation and Troop Cmd ATTN: SATAI-A

US Army Comm-Elec Cmd ATTN: AMSEL-SF-REE

US Army Depot System Cmd ATTN: AMSDS-IN-E

US Army Missile Cmd ATTN: AMSMI-RA

US Army Tank-Automotive Cmd ATTN: AMSTA-XEM/AMSTA-XA

US Army Test \& Eval Cmd ATTN: AMSTE-EQ

White Sands Missile Range ATTN: STEWS-ES-E

Charles Melvin Price Spt Ctr ATTN: SATAS-F

US Army Arm. Res Devel \& Engr Ctr ATTN: AMSTA-AR-ISE-UL

US Army Natick Res Devel \& Engr Ctr ATTN: SATNC-ZSN

Pine Bluff Arsenal ATTN: SMCPB-EMB

Rock Island Arsenal ATTN: SMCRI-PWB ATTN: AMSCM-EHR

Watervliet Arsenal ATTN: SMCWV-PW

US Army Dugway Proving Ground ATTN: STEDP-EPO-CP

US Army Jefferson Proving Ground ATTN: STEJP-EH-R

US Army Yuma Proving Ground ATTN: STEYP-ES-E

Anniston Army Depot ATTN: SDSAN-DPW-PED

Blue Grass Army Depot ATTN: SDSBG-EN 
Red River Army Depot ATTN: SDSRR-OE

Sacramento Army Depot ATTN: SDSSA-EL-MO

Sierra Army Depot ATTN: SDSSI-ENV

Tobyhanna Army Depot ATTN: SDSTO-EM

US Army Depot-Hawthorne ATTN: SMCHW-ORE

Pueblo Army Depot Activity ATTN: SDSTE-PU-SE

Savanna Army Depot Activity ATTN: SDSLE-VA

Seneca Army Depot Activity ATTN: SDSTO-SEI-PE

Umatilla Army Depot Acitivty ATTN: SDSTE-UAS-EVE

McAlester Army Ammunition Plant ATTN: SMCMC-DEL

Holston Army Ammunition Plant ATTN: SMCHO-EN

Indiana Army Ammunition Plant ATTN: SMCIN-EN

lowa Army Ammunition Plant ATTN: SMCIO-PPE

Kansas Army Ammunition Plant ATTN: SMCKA-OR

Lake City Army Ammunition Plant ATTN: SMCLC-EN

Lone Star Army Ammunition Plant ATTN: SMCLS-SEE

Longhorn/Louisiana Army Ammo Plant ATTN: SMCLO-EN

Milan Army Ammunition Plant ATTN: SMCMI-IO

Mississippi Army Ammunition Plant ATTN: SMCMS-CA

Newport Army Ammunition Plant ATTN: SMCNE-EN

Radford Army Ammunition Plant ATTN: SMCRA-OR

Sunflower Army Ammuniton Plant ATTN: SMCSU-EN

US Army Aberdeen Proving Ground Spt Acty ATTN: STEAP-FE-G/STEAP-SH-ER ATTN: AMSTE-EQ

Redstone Arsenal Spt Activity ATTN: AMSMI-RA-DPW-MP-PR

US Army TACOM Spt Activity-Selfridge ATTN: AMSTA-CYE

Lima Army Tank Plant

ATTN: DCMDM-PDM

US Army Garrison-Fort Monmouth ATTN: SELFM-PW

Alabama Army Ammunition Plant ATTN: SMCAL

Badger Army Ammunition Plant ATTN: SMCBA-OR

Cornhusker Army Ammunition Plant ATTN: SMCCO

Joliet Army Ammunition Plant ATTN: SMCJO-OR

Ravenna Army Ammunition Plant ATTN: SMCRV-CR

Riverbank Army Ammunition Plant ATTN: SMCRB-CR

St. Louis Army Ammunition Plant ATTN: SATAI-A

Twin Cities Army Ammunition Plant ATTN: SMCTC-EN

Volunteer Army Ammunition Plant ATTN: SMCVO-CR

US Army Research Laboratory ATTN: AMSRL-OP-SD-FE

USAMC, Alexandria, VA 22333-0001

\section{ATTN: AMCEN-F}

National Guard Bureau

ATTN: NGB-ARI

ATTN: NGB-ARE

ATTN: NGB-ARO-TS

Army National Guard

Fort Richardson, AK 99505-5800

Montgomery, AL 36109-0711

Phoenix, AZ 85008-3495

N.Little Rock, AR 72199-9600

Camp Roberts, CA 93451

Sacramento, CA 95826-9101

Los Alamitos, CA 90720

Englewood, CO 80112

Hartford, CT 06105-3795

Washington, DC 20003-1719

Wilmington, DE 19808-2191

St. Augustine, FL 32085-1008

Starke, FL 32091

Atlanta, GA 30316-0965

Tamuning, GU 96911-4421

Honolulu, HI 96816-4495

Boise, ID 83705-8095

Springfield, IL 62702-2399

Indianapolis, IN 46241-4839

Johnston, IA 50131-1902

Topeka, KS 66611-1159

Frankfort, KY 40601-6168

New Orleans, LA 70146-0330

Camp Edwards, MA 02542-5003

Milford, MA 01757

Baltimore, MD 21201-2288

Augusta, ME 04333-0033

Lansing, MI 48913-5101

Little Falls, MN 56345-0348

Jackson, MS 39209

Camp Shelby, MS 39407-5500

Jefferson City, MO 65101-9051

Helena, MT 59604-4789

Lincoln, NE 68508-1090 (2)

Concord, NH 03301-5353

Trenton, NJ 08625-0340

Santa Fe, NM 87505

Carson City, NV 89701-5596

Raleigh, NC 27607-6410

Bismark, ND 58502-5511

Latham, NY 12110-2224

Columbus, $\mathrm{OH} 43235-2789$

Camp Gruber, OK 74423

Oklahoma City, OK 73111-4389

Salem, OR 97309-5047

Annville, PA 17003-5002

San Juan, PR 00904

Providence, RI 02904-5717

Eastover, SC 29244

Columbia, SC 29201

Rapid City, SD 57702-8186

Austin, TX 78763-5218

Draper, UT 84020-1776

Richmond, VA 23219

Kings Hill, VI 00850-9764

Colchester, VT 05446-3004

Spokane, WA 99219-9069

Tacoma, WA 98430-5054

Madison, WI 53714-0587

Charleston, WV 25311-1085

Cheyenne, WY 82003

Headquarters, Army Environmental Ctr ATTN: SFIM-AEC-ECA

ATTN: SFIM-AEC-NR 21010

ATTN: SFIM-AEC-CR 64152

ATTN: SFIM-AEC-SR 30335-6801

ATTN: AFIM-AEC-WR 80022-2108
Tyndall AFB 32403

ATTN: HQAFCESA/CES

ATTN: Engrg \& Service Lab

Fort Belvoir 22060

ATTN: CETEC-IM-T

ATTN: CETEC-ES 22315-3803

ATTN: Water Resources Support Ctr

National Inst. of Stds and Technology ATTN: Library 20899

INSCOM 22186

ATTN: IALOG-I

ATTN: IAV-DPW

Information Systems Cmd

ATTN: ASH-CPW-B

USATACOM

ATTN: AMSTA-XE

CEWES 39180

ATTN: Library

CECRL 03755

ATTN: Library

Military District of Washington, Fort McNair ATTN: ANEN 20319

US Military Academy 10996

ATTN: MAEN-A

ATTN: DOPS

ATTN: Facilities Engineer

ATTN: Geography \& Envr Engrg

Naval Facilities Engr Command

ATTN: Facilities Engr Command

Code 03 (2)

Code 04

Code 20

Code 10

Code 03T

Code Fac-03

Code 21

ATTN: Division Offices, Northern Div

ATTN: Code 9A

ATTN: Code 1021/FLG

Chesapeake Division

ATTN: Code 0420374

Atlantic Division 23511

ATTN: Code 09B

ATTN: Code 09A

Southern Division 29411

ATTN: RDT\&E Liaison Office (2)

Western Division 94066

ATTN: Code 203

ATTN: RDT\&E Liaison Officer

Pacific Division 96860

ATTN: Code 04B (2)

US Govt Printing Office 20401

ATTN: Rec Sec/Deposit Sec (2)

Defense Technical Info Ctr 22304 ATTN: DTIC-FAB (2) 